\title{
Movement of the Saltwater Interface in the Surficial Aquifer System in Response to Hydrologic Stresses and Water-Management Practices, Broward County, Florida
}

By Alyssa Dausman and Christian D. Langevin

Prepared in cooperation with the

SOUTH FLORIDA WATER MANAGEMENT DISTRICT

Scientific Investigations Report 2004-5256 


\title{
U.S. Department of the Interior \\ Gale A. Norton, Secretary
}

\section{U.S. Geological Survey Charles G. Groat, Director}

\section{U.S. Geological Survey, Reston, Virginia: 2005}

\author{
For sale by U.S. Geological Survey, Information Services \\ Box 25286, Denver Federal Center \\ Denver, CO 80225 \\ For more information about the USGS and its products: \\ Telephone: 1-888-ASK-USGS \\ World Wide Web: http://www.usgs.gov/
}

\begin{abstract}
Any use of trade, product, or firm names in this publication is for descriptive purposes only and does not imply endorsement by the U.S. Government.

Although this report is in the public domain, permission must be secured from the individual copyright owners to reproduce any copyrighted materials contained within this report.
\end{abstract}

Suggested citation:

Dausman, Alyssa, and Langevin, C.D., 2005, Movement of the Saltwater Interface in the Surficial Aquifer System in Response to Hydrologic Stresses and Water-Management Practices, Broward County, Florida: U.S. Geological Survey Scientific Investigations Report 2004-5256, 73 p. 


\section{Contents}

Abstract........................... 1

Introduction .................... 2

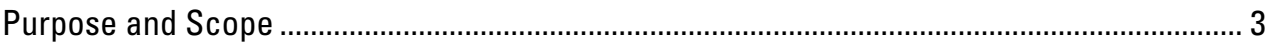

$\begin{array}{ll}\text { Previous Studies .. } & 3\end{array}$

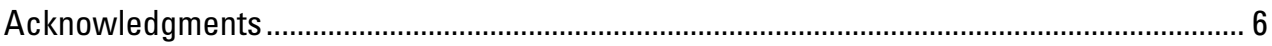

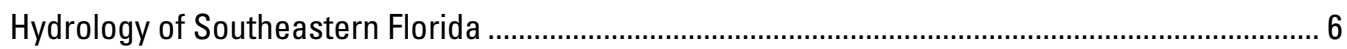

Hydrogeologic Units and Aquifer Properties ................................................................... 6

Hydrologic Stresses .................................................................................................... 10

Rainfall and Evapotranspiration ............................................................................... 10

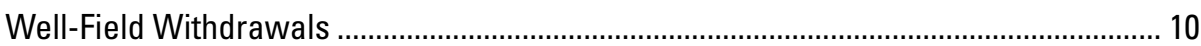

Canal Stage $\quad 10$

Saltwater Intrusion in the Biscayne Aquifer ........................................................................ 11

Collection and Interpretation of Field Data ................................................................................... 17

Well Selection and Continuous Monitoring..................................................................................... 17

Influences on the Saltwater Interface ................................................................................ 19

Tides ........ 19

Rainfall and Control Structure Openings ......................................................................... 22

Response to Water-Level Changes Near Structure S-36 ........................................ 22

Response to Water-Level Changes Near Structure S-13 ......................................... 24

Data Exploration with Artificial Neural Networks and Regression............................... 25

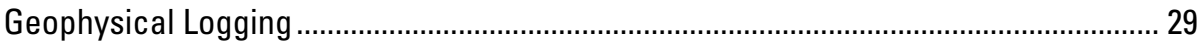

Numerical Simulation of Saltwater Interface Movement in Response to Water-Level

Fluctuations .............. 31

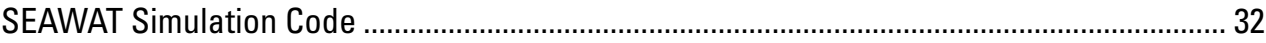

Model Design .....

Initial Water Levels and Salinity Concentrations ........................................................... 32

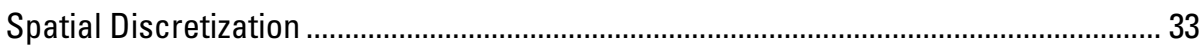

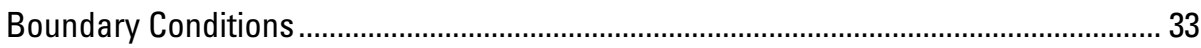

Estimation of Representative Aquifer Parameters............................................................... 33

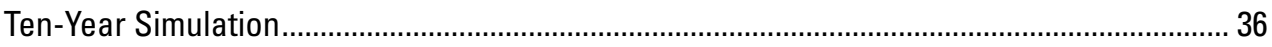

Ground-Water Flow Patterns and Water Budget........................................................... 37

Comparison of Model Results with Field Data ................................................................... 38

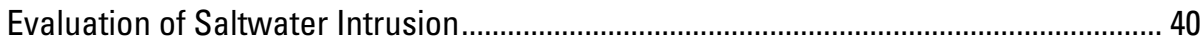

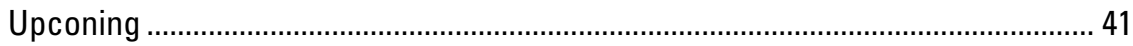

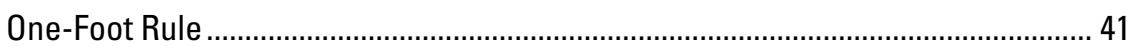

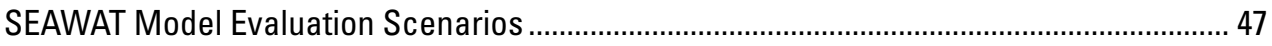

Canal Stage $\quad 47$

Drought with Increased Ground-Water Withdrawals ................................................... 48

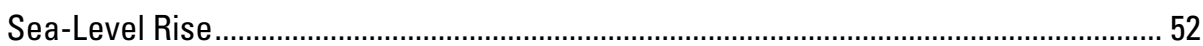

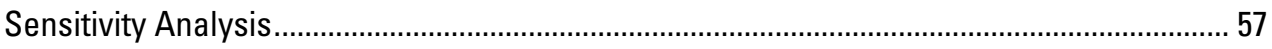

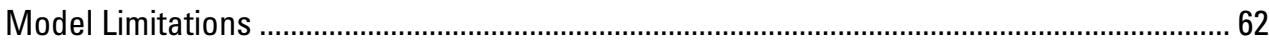




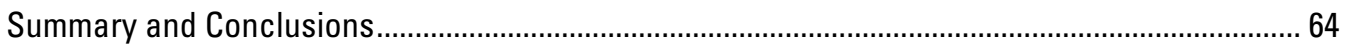

References Cited ........ 64

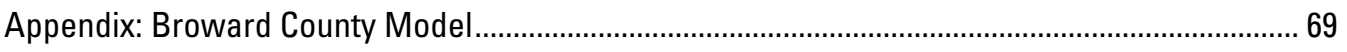

\section{Figures}

1-5. Maps showing:

1. Study area in Broward County, Florida

2. Position of the saltwater interface, altitude of the water table, location of the saltwater intrusion line, well fields, and control structures in Broward County and adjacent areas..

3. Position of the saltwater interface, location of the saltwater intrusion line, and control structures in southeastern Florida....................................................... 5

4. Hydrologic features of southern Florida................................................................. 7

5. Physiographic features of eastern Broward County ............................................... 8

6. Generalized hydrogeologic section of Broward County ................................................... 9

7. Map showing South Florida Water Management District rainfall stations used in the analyses.

8. Graph showing monthly rainfall totals and withdrawals at the Five Ash/Prospect Well Field area in Broward County, 1990-99

9. Graph showing lines of equal chloride concentration and toe location in the Silver Bluff area, Miami-Dade County, November 2, 1954

10. Map showing position of the saltwater interface and location of selected wells used for continuous monitoring in eastern Broward County...

11. Map showing location of all wells used in the study for data collection or interpretation

12-21. Graphs showing:

12. Ground-water chloride concentrations in the Oakland Park area, 1964-2000....... 16

13. Ground-water chloride concentrations in southern Broward County, 1964-2000

14. Water level and specific conductance for well G-2270, and upstream and downstream canal stage at structure S-13, and average rainfall in Broward County, April 2001 to July 2002

15. Continuous 15-minute record of water-level and specific conductance data for selected monitoring wells, and downstream stage and rainfall at structure S-36

16. Specific conductance and water-level fluctuations for wells G-2897 and G-2898, and countywide average rainfall and upstream and downstream stage at structure S-36 during September 6-19, 2001

17. Specific conductance and water-level fluctuations for wells G-2270, G-2784, G-2785, and G-2900, and rainfall and upstream and downstream stage at structure S-13 during September 6-19, 2001.

18. Water-level data for wells G-2784 and G-2785, and rainfall and vertical flow direction in the Biscayne aquifer calculated using the data from both wells during April 18 to May 1, 2002, and March 23 to April 5, 2001 
19. Daily ground-water level averages and rainfall data in Broward County, March 2001 to May 2002.

20. Pumpage from the Five Ash/Prospect Well Field and average daily water levels in well G-2898, March 2001 to May 2002, and linear regression of Five Ash/Prospect pumpage and well G-2898 water levels

21. Measured and simulated specific conductance in wells G-2897, G-2898, G-2785, and G-2900 based on the Artificial Neural Networks model, March 2001 to June 2002

22. Geophysical logs of wells G-2897, G-2900, and G-2898 showing bulk conductivity with depth, 2000-03

23. Schematic showing conceptual view of an area where the northern part is symmetrical to the southern part, and map view and cross-sectional view of model grid showing three-dimensional representative model with boundary conditions and aquifer parameters

24. Graph showing stage measured at structure $S-36$ (downstream) compared to stage modeled using the sine function

25. Graph showing upstream and downstream canal stage input for the 10-year (1990-99) simulation.

26. Section showing map view of water-level contours from model results during a wet period (stress period 8) in August and a dry period (stress period 12) in December.......

27. Bar graphs showing water budget for the 10-year (1990-99) simulation 39

28. Map showing location of selected wells used for water-level data collection in the Five Ash/Prospect Well Field area

29. Graphs showing comparison of measured and simulated water-level data from wells G-820A, G-2033, G-2443, and G-2444 in the Five Ash/Prospect Well Field area during 1990-99

30. Map view showing comparison of the measured and simulated saltwater toe locations at the base of the Biscayne aquifer and the simulated toe locations at the base of the surficial aquifer system at the end of the 10-year simulation

31. Graph and grids showing relation between salinity concentration and time at selected cells in the 10-year model, cross-sectional view of the model depicting the depth of each observation cell, and map view of the model depicting the areal location of each observation cell..

32. Graph showing head difference between upstream and downstream canal stage in the model and total dissolved-solids concentration beneath the canal.

33. Cross-sectional view of model grid depicting upconing beneath the well field for the end of the 10-year simulation.

34-38. Graphs showing

34. Head difference between two observation wells (X and $Y$ ) used to establish the 1 -foot (0.3048-meter) rule compared to the total dissolved-solids concentration at the saltwater interface measured at observation well $Y$

35. Linear regression of the head difference between two observation wells and the change in total dissolved-solids concentration of the observation well at the saltwater interface.

36. Linear regression of the rainfall in the model and the change in total dissolved-solids concentration (from one month to the next) of observation well $Y$ at the saltwater interface. 
37. Linear regression of the difference between the upstream and downstream canal stage and total dissolved-solids concentration at an observation well beneath the downstream canal

38. Observed and simulated difference in heads between observation wells using rainfall, pumpage, and change in upstream and downstream canal stage in a multivariate regression.

39. Map views showing toe movement at the base of the surficial aquifer system in the model over time for the simulation representing canal stage change...

40. Graph and grids showing total dissolved-solids concentrations (at observation cells) for the canal stage change scenario, cross-sectional view of the model depicting the depth of each observation cell, and map view of the model depicting the areal location of each observation cell.

41. Cross-sectional view through row 1 depicting the 250-milligram per liter chloride concentration contour and the 50- and 97-percent seawater contours 50 years after the canal stage change is lowered 1 foot

42. Graph showing evaluation of the 1-foot rule for the canal stage change scenario 50

43. Graph showing rainfall and half the pumpage for the 10-year (1990-99) simulation modified with 3 years of drought and 3 years of increased pumpage at the beginning of the simulation

44. Map view showing toe movement at the base of the surficial aquifer system in the model over time for the simulation representing decreased rainfall and increased pumpage.........

45. Graph and grids showing total dissolved-solids concentration during the simulated drought subtracted from the 10 -year base simulation, cross-sectional view of the model depicting the depth of each observation cell, and map view of the model depicting the areal location of each observation cell

46. Cross-sectional view through row 1 depicting the 250-milligram per liter chloride concentration contour and the 50- and 97-percent seawater contours based on the simulated drought scenario

47. Graph showing evaluation of the 1 -foot rule for the simulated drought scenario............. 54

48. Graph showing sea-level elevation input for the sea-level rise evaluation scenario....... 55

49. Map view showing inland toe movement at the base of the surficial aquifer system in the model over time for the simulation representing effect of sea-level rise

50. Graph showing total dissolved-solids concentrations at observation cells in the sea-level rise simulation, cross-sectional view of the model depicting the depth of each observation cell, and map view of the model depicting the areal location of each observation cell

51. Cross-sectional view through row 1 depicting the 250-milligram per liter chloride concentration contour and the 50 - and 97-percent seawater contours based on the sea-level rise scenario.

52. Graph showing elevation of the 1 -foot rule for the sea-level rise scenario

53. Cross-sectional view of simulated observation wells $P$ and $Q$ for a sensitivity analysis to evaluate the change in total dissolved-solids concentration

54-55. Graphs showing total dissolved-solids concentration over time at simulated observation wells $P$ and $Q$, resulting from changes in:

54. Horizontal hydraulic conductivity in the Biscayne aquifer and lower part of the surficial aquifer system......

55. Longitudinal and transverse dispersivities 
56. Cross-sectional view of model grid depicting the toe (250-milligram per liter chloride concentration contour) for the 10 -year simulation, with longitudinal dispersivity increased and decreased 50 percent.

57-59. Graphs showing total dissolved-solids concentration over time at simulated observation wells $P$ and $Q$, resulting from changes in:

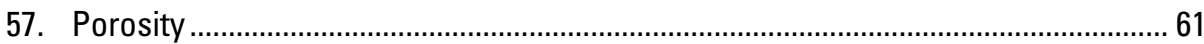

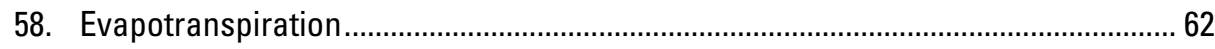

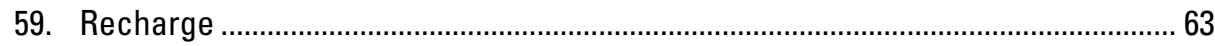

A1. Map showing location of study area for the Broward County model, Broward County, Florida 70

A2. Second layer of the Broward County model with South Florida Water Management District MODFLOW boundaries and active cells, and SEAWAT model boundaries and active cells

A3. Maps showing results from the variable-density Broward County model created from SEAWAT.

\section{Tables}

1. Wells used for continuous monitoring in eastern Broward County and their distance from the nearest canal, nearest control structure, and the coast 19

2. Measured and simulated salinity and water-level data from selected continuous monitoring wells in Broward County. 


\section{Conversion Factors, Vertical Datum, and Acronyms}

\begin{tabular}{rcl} 
Multiply & By & \multicolumn{1}{c}{ To obtain } \\
meter $(\mathrm{m})$ & 3.281 & foot \\
meter per day $(\mathrm{m} / \mathrm{d})$ & 3.281 & foot per day \\
square meter per day $\left(\mathrm{m}^{2} / \mathrm{d}\right)$ & 10.76 & square foot per day \\
cubic meter per day $\left(\mathrm{m}^{3} / \mathrm{d}\right)$ & 35.31 & cubic foot \\
kilometer $(\mathrm{km})$ & 0.6214 & mile \\
centimeter $(\mathrm{cm})$ & $3.281 \times 10^{-2}$ & foot $(\mathrm{ft})$ \\
centimeter per day $(\mathrm{cm} / \mathrm{d})$ & $3.281 \times 10^{-2}$ & foot per day \\
centimeter per year $(\mathrm{cm} / \mathrm{yr})$ & $3.281 \times 10^{-2}$ & foot per year \\
kilogram per cubic meter $\left(\mathrm{kg} / \mathrm{m}^{3}\right)$ & 0.06243 & pound per cubic foot \\
gram per liter $(\mathrm{g} / \mathrm{L})$ & 1,000 & parts per million \\
\hline
\end{tabular}

Vertical coordinate information is referenced to the National Geodetic Vertical Datum of 1929 (NGVD 29); horizontal coordinate information is referenced to the North American Datum of 1983 (NAD 83).

Temperature in degrees Celsius $\left({ }^{\circ} \mathrm{C}\right)$ may be converted to degrees Fahrenheit $\left({ }^{\circ} \mathrm{F}\right)$ as follows: ${ }^{\circ} \mathrm{F}=1.8 \mathrm{x}{ }^{\circ} \mathrm{C}+32$

\section{Acronyms}

\begin{tabular}{r|l} 
ANN & Artificial Neurological Networks \\
CHD & Constant head \\
GHB & General-head boundary \\
GIS & Geographic information system \\
MWA & Moving window average \\
NWIS & National Water Inventory System \\
SFWMD & South Florida Water Management District \\
USGS & U.S. Geological Survey
\end{tabular}




\title{
Movement of the Saltwater Interface in the Surficial Aquifer System in Response to Hydrologic Stresses and Water-Management Practices, Broward County, Florida
}

\author{
By Alyssa Dausman and Christian D. Langevin
}

\begin{abstract}
A study was conducted to evaluate the relation between water-level fluctuations and saltwater intrusion in Broward County, Florida. The objective was achieved through data collection at selected wells in Broward County and through the development of a variable-density ground-water flow model. The numerical model is representative of many locations in Broward County that contain a well field, control structure, canal, the Intracoastal Waterway, and the Atlantic Ocean. The model was used to simulate short-term movement (from tidal fluctuations to monthly changes) and long-term movement (greater than 10 years) of the saltwater interface resulting from changes in rainfall, well-field withdrawals, sea-level rise, and upstream canal stage. The SEAWAT code, which is a combined version of the computer codes, MODFLOW and MT3D, was used to simulate the complex variable-density flow patterns.

Model results indicated that the canal, control structure, and sea level have major effects on ground-water flow. For periods greater than 10 years, the upstream canal stage controls the movement and location of the saltwater interface. If upstream canal stage is decreased by 1 foot ( 0.3048 meter), the saltwater interface takes 50 years to move inland and stabilize. If the upstream canal stage is then increased by 1 foot ( 0.3048 meter), the saltwater interface takes 90 years to move seaward and stabilize. If sea level rises about 48 centimeters over the next 100 year as predicted, then inland movement of the saltwater interface may cause well-field contamination.

For periods less than 10 years, simulation results indicated that a 3-year drought with increased well-field withdrawals probably will not have long-term effects on the position of the saltwater interface in the Biscayne aquifer. The saltwater
\end{abstract}

interface returns to its original position in less than 10 years. Model results, however, indicated that the interface location in the lower part of the surficial aquifer system takes longer than 10 years to recover from a drought. Additionally, rainfall seems to have the greatest effect on saltwater interface movement in areas some distance from canals, but the upstream canal stage has the greatest effect on the movement of the saltwater interface near canals.

Field data indicated that saltwater interface movement includes short-term fluctuations caused by tidal fluctuations and long-term seasonal fluctuations. Statistical analyses of daily-averaged data indicated that the saltwater interface moves in response to pumpage, rainfall, and upstream canal stage. In areas near the canal, the saltwater interface is most affected by canal stage because water-management structures control the stage in the upstream part of the canal and allow movement of the saltwater interface. In areas away from the canal, the saltwater interface is most affected by pumpage and rainfall, depending on the location of well fields. Data analyses also revealed that rainfall changes the vertical flow direction in the Biscayne aquifer.

Results from the study indicated that upstream canal stage substantially affects the long-term position of the saltwater interface in the surficial aquifer system. The saltwater interface moves faster inland than seaward because of changes in upstream canal stage. For short-term problems, such as drought, the threat of saltwater intrusion in the Biscayne aquifer does not appear to be severe if the well-field withdrawal is increased; however, this conclusion is based on the assumption that well-field withdrawals will decrease once the drought is over. Sea-level rise may be a potential threat to the water supply in Broward County as the saltwater interface moves inland toward well fields. 


\section{Introduction}

Saltwater intrusion is a potential threat to the potable water supply in Broward County (fig. 1) and surrounding areas along the southeastern coast of Florida. This complicates the management of ground-water resources along the coastal region where competing flood protection and water-supply needs must be satisfied. Specifically, saltwater intrusion is of concern because it can contaminate freshwater in the surficial aquifer system, which includes the lower part of the surficial aquifer system and the Biscayne aquifer (the upper part); the Biscayne aquifer is the principal source of potable water in southeastern Florida.

Based on historical data and hydrogeologic principles, the water-level fluctuations created by changes in canal stage can affect the position of the freshwater/saltwater interface (hereafter referred to as the saltwater interface). The relation, however, has not been defined for southern Florida. The South Florida Water Management District (SFWMD) is currently defining "Minimum Flows and Levels" for this region (South Florida Water Management District, 2000b); the effort includes setting a "Minimum Canal Operation Level" defined as "the minimum water level in a canal... if managed for a specific period of time [that] is sufficient to restrict saltwater intrusion within the coastal Biscayne aquifer and prevent significant harm from occurring during a period of deficient rainfall." A statistical analysis by the SFWMD, however, has shown little correlation between the altitude of the water table and movement of the saltwater interface (South Florida Water Management District, 2000b).

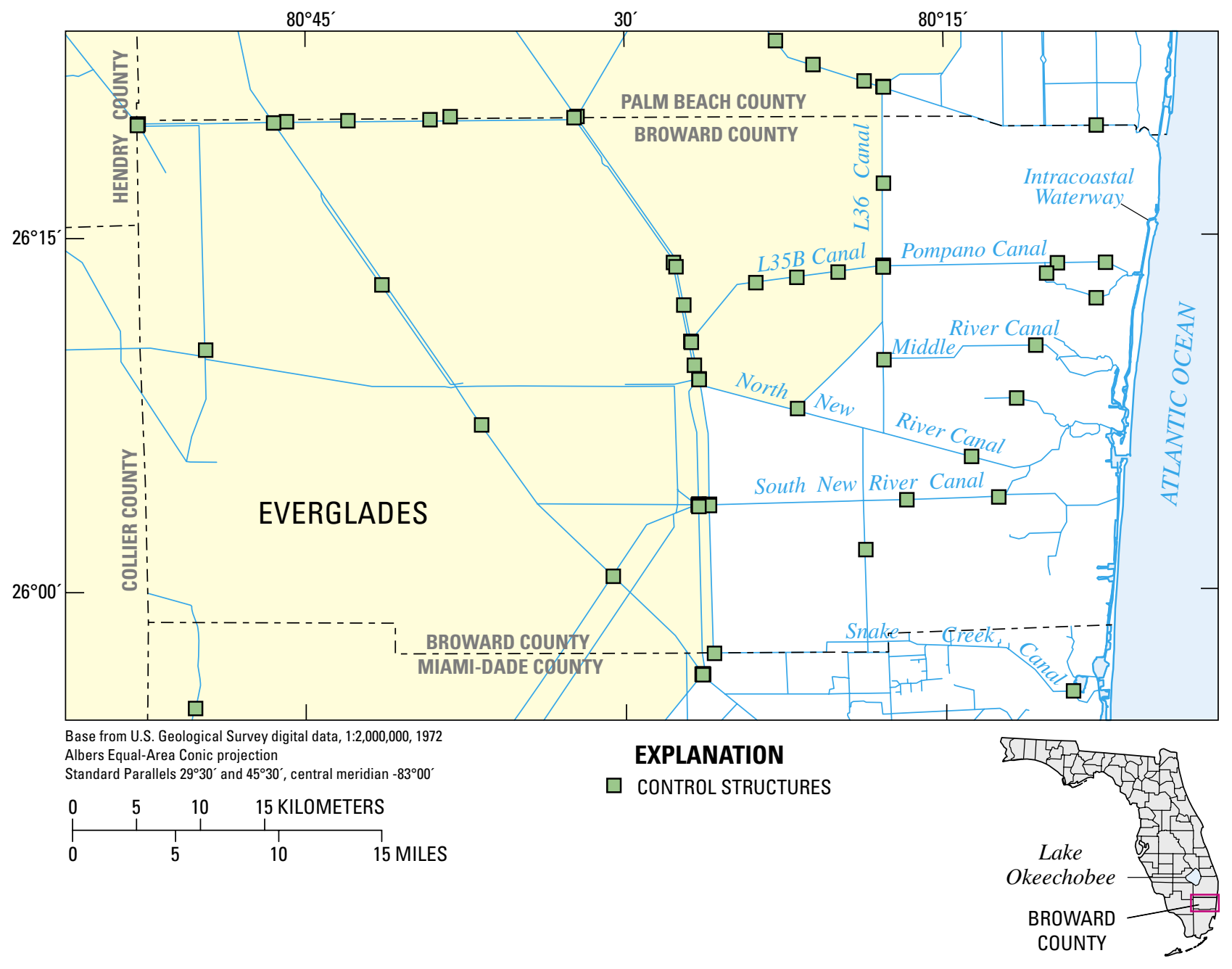

Figure 1. Study area in Broward County, Florida. 
The U.S. Geological Survey (USGS), in cooperation with the SFWMD, began a study in 2001 to evaluate the relation between canal stage and saltwater intrusion in Broward County. The study was subsequently broadened to examine the effects of well-field withdrawals, tides, recharge, and sea-level rise on the movement of the saltwater interface. This expansion of scope was necessary after it was determined that: (1) these additional factors affect saltwater interface movement and (2) their effects cannot be isolated from those of canal stage. The study was accomplished through field work involving continuous water-level and specific conductance monitoring as well as geophysical logging. A representative numerical model also was constructed to aid in accomplishing the objectives.

\section{Purpose and Scope}

The purpose of this report is to describe the movement of the saltwater interface in response to hydrologic stresses and water-management factors in Broward County, southeastern Florida. The report documents project activities that included: (1) compiling and analyzing hydrologic data collected as part of the study to describe the hydrology of southeastern Florida; (2) using a three-dimensional variable density numerical ground-water model to simulate the movement of the saltwater interface in response to environmental stresses; and (3) using field data, statistical analyses, and model results to quantify the relation between hydrologic stresses and water-management factors and movement of the saltwater interface.

This report discusses continuous ground-water level and specific conductance data used to develop accurate aquifer parameters and boundary conditions for a representative numerical model. This representative three-dimensional, variable-density, numerical ground-water model was developed to simulate saltwater interface movement in response to canal stage fluctuations, well-field withdrawals, recharge and sea-level rise. Simulation scenarios are presented to evaluate the response of the saltwater interface to seasonal and multiyear stresses.

\section{Previous Studies}

Saltwater intrusion occurs in coastal aquifers when saline ground water intrudes and contaminates a freshwater aquifer. Mixing occurs in the aquifer at the interface between fresh ground water and saline water. This mixing zone is referred to as the saltwater interface. The extent of saltwater intrusion, or the inland position of the saltwater interface, is highly dependent on freshwater levels within the aquifer. If water levels increase in the freshwater part of the aquifer, the interface can move seaward; however, if water levels decrease, the interface may move inland and pose a potential threat to municipal well fields. Movement of the interface is not instantaneous. Months, years, or decades may be required before the interface reaches equilibrium with surrounding water levels.
Previous studies of the location of the saltwater interface in parts of southeastern Florida indicated that the interface does not coincide with the location predicted by the GhybenHerzberg principle. For example, in southern Broward County and northern Miami-Dade County, the actual position of the saltwater interface (figs. 2 and 3, respectively) is closer to the coast than predicted by the Ghyben-Herzberg equation (Cooper and others, 1964; Merritt, 1996; Konikow and Reilly, 1999). This could mean that: (1) the interface position has not yet stabilized and, therefore, is continuing to move inland at a very slow rate; or (2) the interface position has stabilized, and processes such as dispersion are causing the interface position to deviate from the position estimated by the Ghyben-Herzberg principle (Cooper, 1959). In these areas, more complex numerical models that include the dispersion process are required to resolve the Ghyben-Herzberg discrepancy and predict future movement of the saltwater interface.

Numerous water-quality and saltwater intrusion studies of the surficial aquifer system have been conducted in southeastern Florida. Some of the water-quality studies related to saltwater intrusion include: Vorhis (1948), Schroeder and others (1958), Sherwood (1959), Cooper (1959), Tarver (1964), Grantham and Sherwood (1968), McCoy and Hardee (1970), Bearden (1972, 1974), Leach and others (1972), Sherwood and others (1973), Howie (1987), Koszalka (1995), and Dunn (2001).

Other studies that deal specifically with saltwater intrusion in southeastern Florida include: Parker and others (1944), Brown and Parker (1945), Parker (1945), Hoy and others (1951), Hoy (1952), Kohout and Hoy (1953), Parker and others (1955), Klein (1957), Kohout (1960a; 1960b; 1961a; 1961b; 1964; 1967), Klein (1965), Leach and Grantham (1966), Rodis (1973), Land and others (1973), Land (1975), Segol and Pinder (1976), Scott and others (1977), Swayze (1980a; 1980b; 1980c; 1980d), Klein and Waller (1985), Sonntag (1987), Klein and Ratzlaff (1989), Sonenshein and Koszalka (1996), Technos, Inc. (1996), Merritt (1997), Sonenshein (1997), and Hittle (1999).

Several numerical models of ground-water flow have been developed for Broward County in recent years. Restrepo and others (1992) and the SFWMD (2000a) designed ground-water models to address problems associated with water-supply issues; however, these models do not include a variable-density component. Because of the numerical difficulties and computer run times associated with variabledensity modeling, regional three-dimensional variable-density models are not often used in practice. Two models designed to evaluate saltwater intrusion in southern Broward County are described by Anderson and others (1988) and Merritt (1996); however, neither model is specifically designed to evaluate the effect of water-level fluctuations on saltwater intrusion. Other variable-density models developed for southern Florida to evaluate ground-water flows or saltwater intrusion are described by Kwiatkowski (1987), Langevin (2001), and Shoemaker and Edwards (2003). 


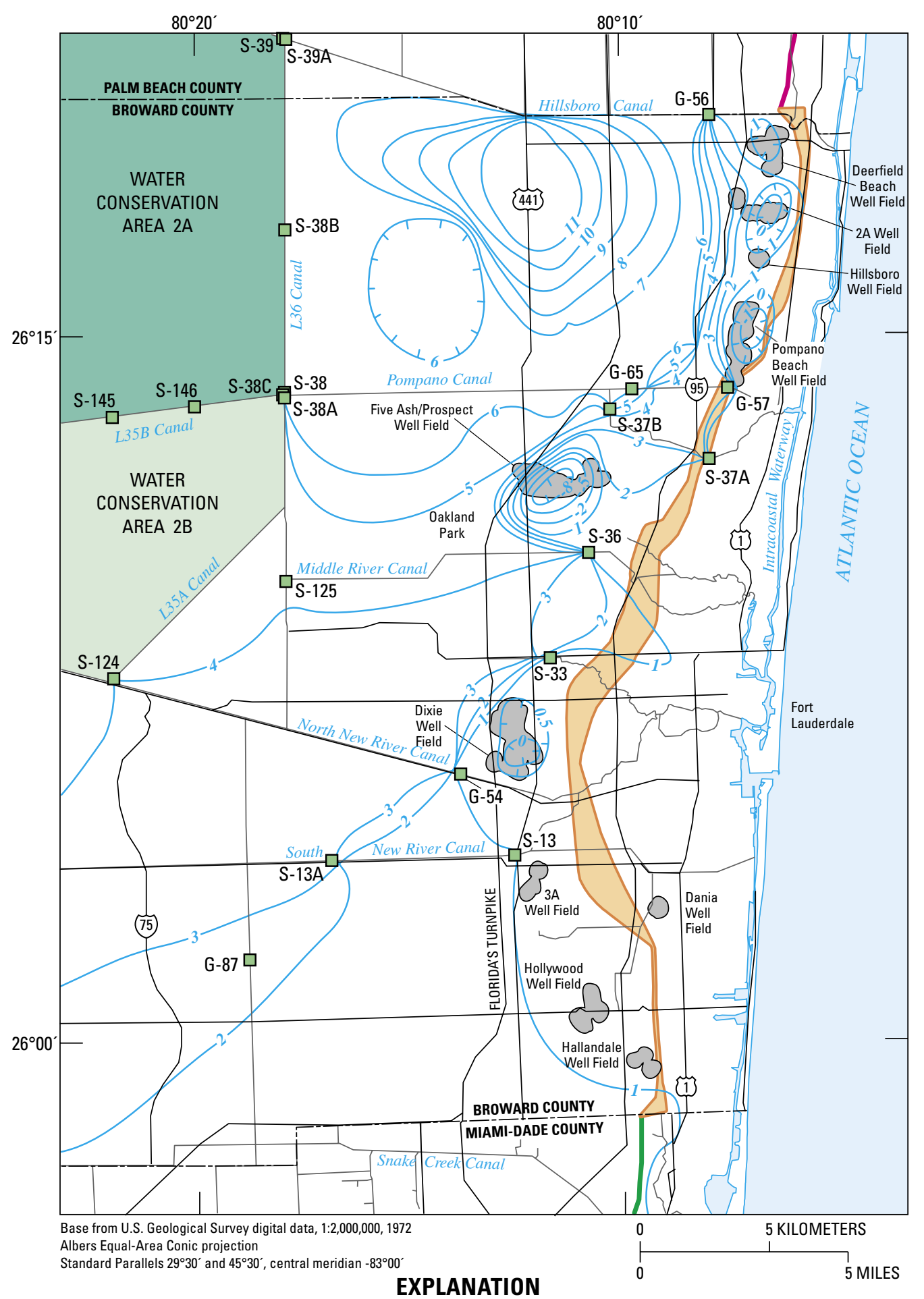

APPROXIMATE POSITION OF SALTWATER INTERFACE (Broward County Department of Planning and Environmental Protection, 2000)

1997-98 SALTWATER INTRUSION LINE IN PALM BEACH COUNTY (Hittle, 1999)

1995 SALTWATER INTRUSION LINE IN MIAMI-DADE COUNTY (Sonenshein, 1997)

-2- APRIL 1988 LINE OF EOUAL GROUND-WATER LEVEL-In feet above NGVD 1929. Intervals are 0.5, 1, and 3 feet. Hatchures indicate depressions (modified from Lietz, 1991)

S- $\square$ - 13 A
CONTROL STRUCTURE AND NUMBER
Figure 2. Position of the saltwater interface, altitude of the water table, location of the saltwater intrusion line, well fields, and control structures in Broward County and adjacent areas. See inset of Florida in figure 1. 


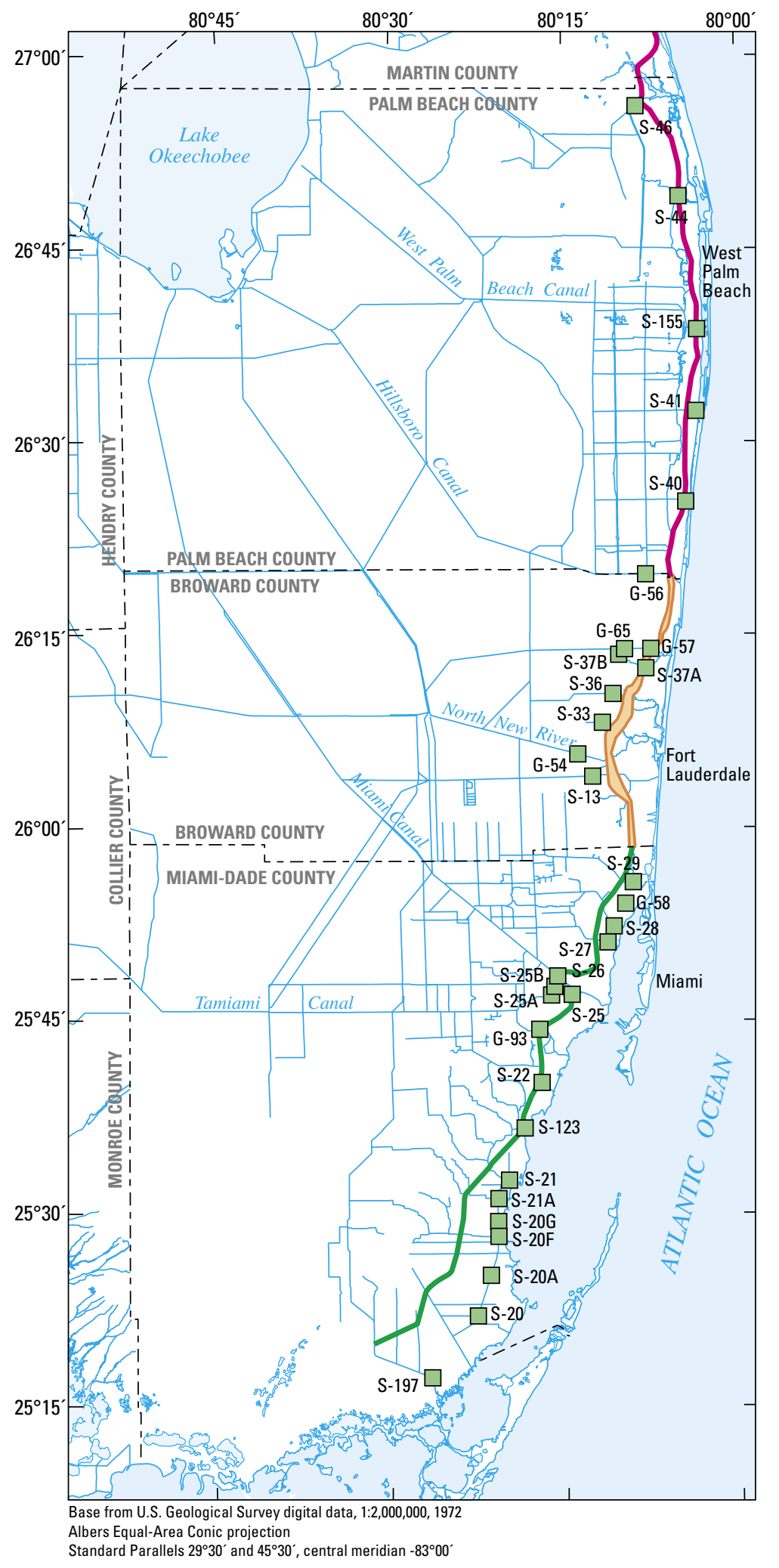

\section{EXPLANATION}

APPROXIMATE POSITION OF SALTWATER INTERFACE (Broward County Department of Planning and Environmental Protection, 2000)

- 1997-98 SALTWATER INTRUSION LINE (Hittle, 1999)

1995 SALTWATER INTRUSION LINE

(Sonenshein, 1997)

S-40

CONTROL STRUCTURE AND NUMBER

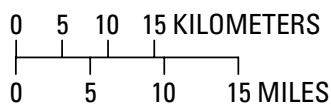

Figure 3. Position of the saltwater interface, location of the saltwater intrusion line, and control structures in southeastern Florida. See inset map of Florida in figure 1. 


\section{Acknowledgments}

Special thanks is extended to Don Charlton, Fran Henderson, Darrel Dunn, Katie Lelis, Dave Markward, and John Horne at the Broward County Environmental Protection Department and the Broward County Office of Environmental Services. Their input was invaluable to the project, having shared years of previous experience and knowledge with project personnel.

Rama Rani and Emily Richards from the SFWMD aided in directing the project to meet the water-management needs of southern Florida. David Garces, a former USGS contract employee, was a major contributor and performed modeling and geographic information system (GIS) techniques that were necessary to complete the project. Jeff Rosenfeld and Diane Ross, formerly with the SFWMD, assisted in well selection for continuous monitoring of water level and salinity. Finally, much appreciation is extended to Craig Canning, Regional Water Facilities Manager for the City of Fort Lauderdale, who fulfilled numerous requests for ground-water withdrawal data in a timely and organized manner.

USGS employees who were integral to the success of the data collection effort include Mike Oliver, Rene Rodriguez, Stephen Bean, Jackie Lima, Emmett McGuire, Scott Prinos, Mitch Murray and John Woolverton. Thanks are also extended to Paul Conrads in South Carolina for his Artificial Neural Networks (ANN) analysis of the collected data.

\section{Hydrology of Southeastern Florida}

An understanding of the hydrologic regime of southeastern Florida is required to accurately simulate and predict movement of the saltwater interface. This section provides a brief description of the hydrostratigraphy of Broward County, the components of the water budget that affect movement of the saltwater interface, and the current state of saltwater intrusion in the Biscayne aquifer. The hydrologic description provides background information that focuses on the data collection, data analyses, and numerical simulations performed as part of this study.

The hydrology of southeastern Florida is unique in that the surface-water system contains the Everglades, which extends south from Lake Okeechobee to Florida Bay. In Broward County, the Everglades is divided into water-conservation areas (fig. 4) that are separated and bounded by canals, levees, and highways. The canal and levee system completed in the 1960's drains parts of the Everglades and prevents flooding in urban and agricultural areas. The canal network conveys water to the Atlantic Ocean primarily during wetseason periods of high water levels, and is used to recharge the surficial aquifer system during dry-season periods of low water levels. Before development of the canals, levees, and highways, the Atlantic Coastal Ridge (fig. 5) was a natural hydrologic barrier between the Everglades and the Atlantic Ocean. The ridge forms the highest ground in Broward County (3-7 $\mathrm{m}$ in elevation) and is up to $7 \mathrm{~km}$ wide. Prior to urbanization, a few shallow rivers cut through the ridge, but as the area was developed, canals were constructed in these low-lying river beds to manage water levels.

To accommodate urban development, levees, canals, and control structures have been designed to control the surface-water and ground-water levels in Broward County (fig. 1). Broward County currently contains areas that are hydrologically separated by canals that run nearly parallel to one another. The canals extend eastward from the Everglades and Lake Okeechobee to the Intracoastal Waterway, which parallels the coastline and is connected to the Atlantic Ocean at several inlets in Broward County. These inlets permit saltwater from the ocean to flow into the Intracoastal Waterway and tidal canals. Near the coast, the canals contain control structures that prevent saltwater from flowing inland. Canals contain freshwater west of the coastal control structures and contain primarily brackish water or saltwater in the tidal sections east of the structures.

The SFWMD manages the canal stage upstream of the coastal control structures by opening and closing structure gates. The threat of flooding increases during large rainfall events. To reduce this risk, gates are opened to lower water levels and release excess runoff prior to large rainfall events. During certain times of the year, high tide can exceed the upstream canal stage. To maintain relatively low inland water levels in this situation, some coastal control structures contain pumps that discharge freshwater from the upstream part of the canal to the downstream part.

\section{Hydrogeologic Units and Aquifer Properties}

This study focuses on evaluating saltwater intrusion in the highly permeable shallow surficial aquifer system, which is the source of potable water in Broward County. The Floridan aquifer system, which underlies the surficial aquifer system, also is highly permeable, but is not discussed in this report nor included in the numerical models owing to the presence of the extensive Hawthorn confining units that hydraulically separate it from the surficial aquifer system.

In Broward County, the surficial aquifer system is divided into the Biscayne aquifer and the lower part of the surficial aquifer system, which includes all units and properties below the Biscayne aquifer and above the intermediate confining unit (fig. 6). The Biscayne aquifer mainly consists of carbonates, sands, and some silt and oolitic material (Causaras, 1985; Fish 1988), and contains the Anastasia Formation, Key Largo Limestone, Fort Thompson Formation, and the limestone and sandstone of the Tamiami Formation. In some areas, the Biscayne aquifer is almost hydraulically separated from the lower part of the surficial aquifer system by the lower permeability materials of the Tamiami Formation. The Biscayne aquifer is greater than $100 \mathrm{~m}$ thick in eastern Broward County 


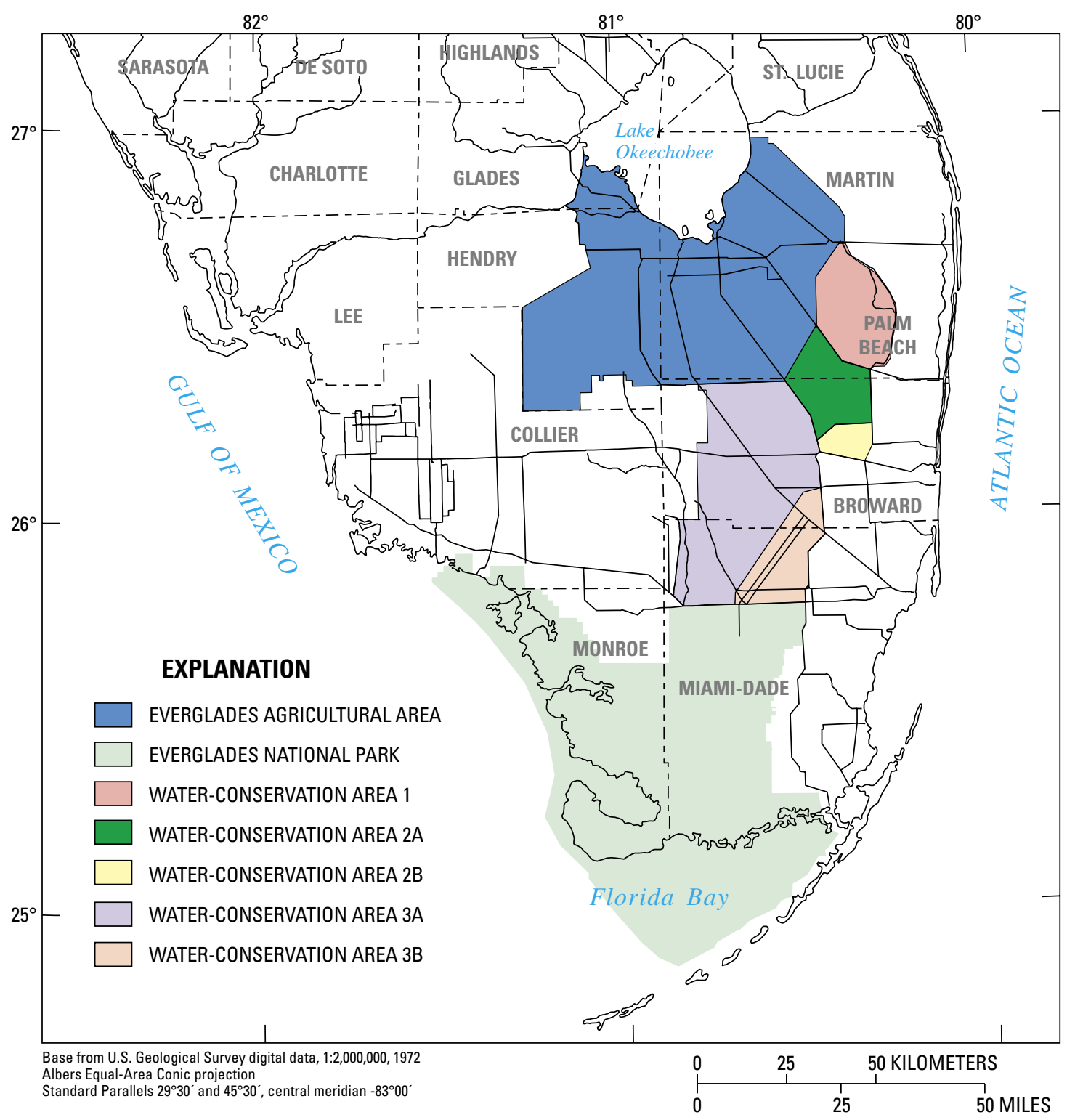

Figure 4. Hydrologic features of southern Florida.

and thins toward the west. In western Broward County, the aquifer is absent (Fish, 1988). Unlike the Biscayne aquifer, the lower part of the surficial aquifer system is thin in eastern Broward County and thickens toward the west.

Hydraulic properties of the Biscayne aquifer vary greatly because of the presence of solution cavities in some zones. Transmissivities in the Biscayne aquifer range from 7,000 $\mathrm{m}^{2} / \mathrm{d}$ in northwestern Broward County to $28,000 \mathrm{~m}^{2} / \mathrm{d}$ in coastal southeastern Broward County (Fish, 1988). Camp, Dresser, and McKee, Inc. (1980) estimated transmissivities in the Biscayne aquifer to range from 9,000 to $24,000 \mathrm{~m}^{2} / \mathrm{d}$. The transmissivities in the lower part of the surficial aquifer system range from 1,900 to $8,200 \mathrm{~m}^{2} / \mathrm{d}$. Horizontal hydraulic conductivities in the Biscayne aquifer are as high as 3,048 m/d (Fish,
1988). Merritt (1996) used a horizontal hydraulic conductivity value of $3,048 \mathrm{~m} / \mathrm{d}$ in the Biscayne aquifer to simulate saltwater intrusion in southern Broward County. The lower part of the surficial aquifer system has substantially lower hydraulic conductivities than the Biscayne aquifer, ranging from 150 to 300 m/d (Fish, 1988). Camp, Dresser, and McKee, Inc. (1980) estimated the ratio of vertical to horizontal permeability in the Biscayne aquifer to range between 1:7 and 1:49.

Fish (1988) reported specific yield values for the Biscayne aquifer in Broward County, ranging from 0.004 to 0.30. Camp Dresser and McKee, Inc. (1980) reported an average specific yield of 0.249 from an aquifer test in the Biscayne aquifer, and values as low as 0.093 may be found in some areas of the Biscayne aquifer. 


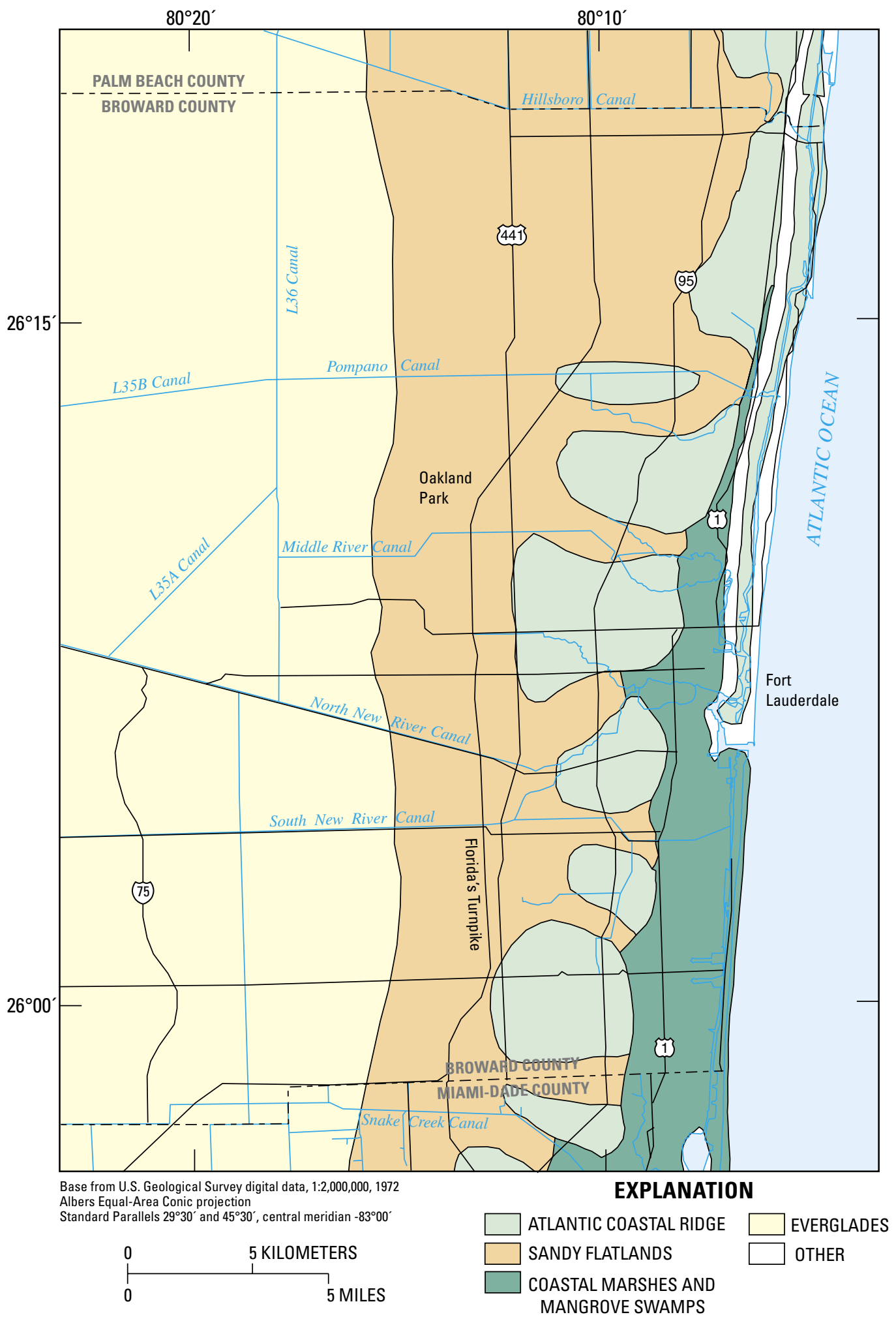

Figure 5. Physiographic features of eastern Broward County (modified from McPherson and Halley, 1996). See inset map of Florida in figure 1. 


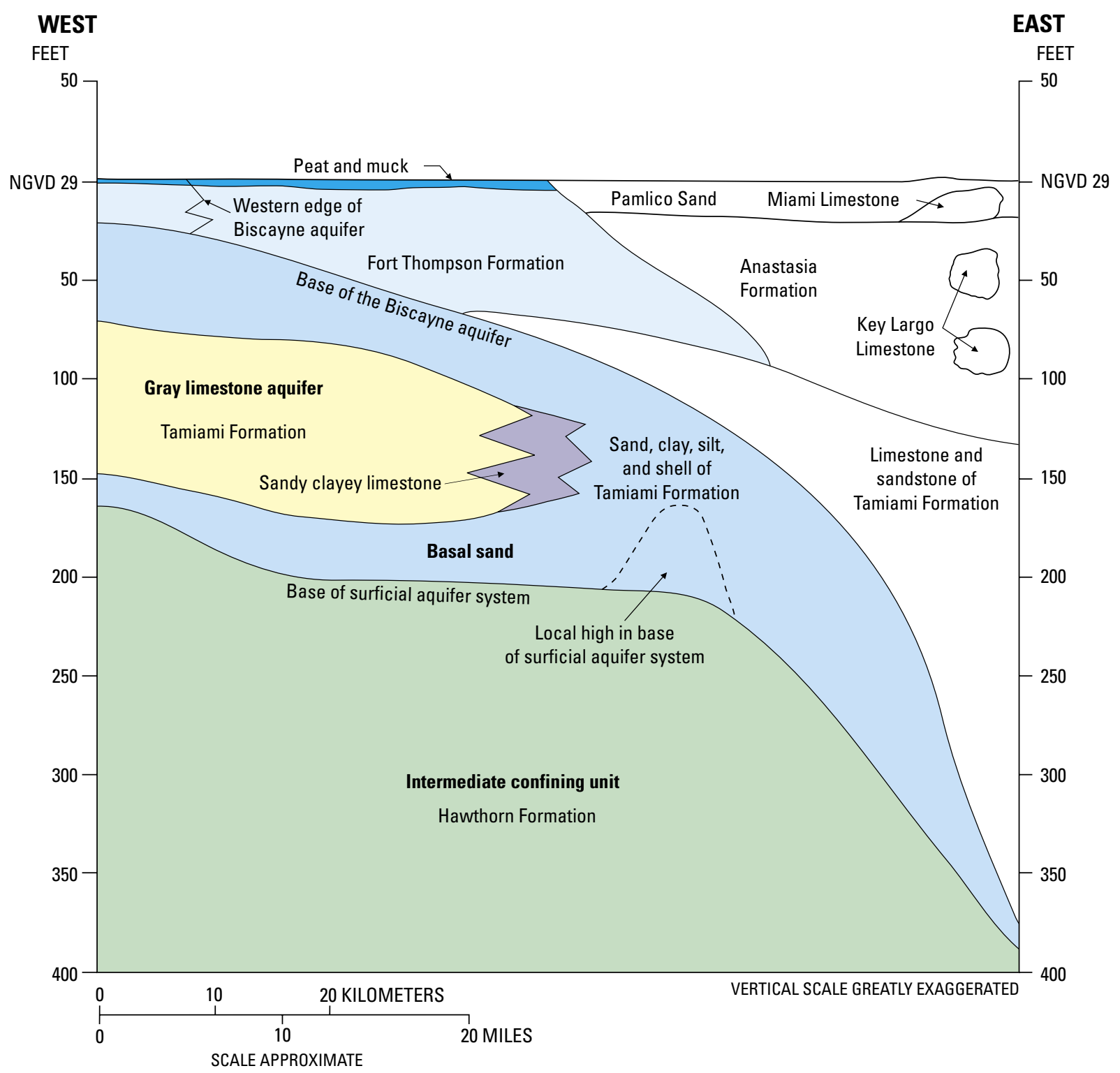

Figure 6. Generalized hydrogeologic section of Broward County (modified from Fish, 1988).

Dispersivity in the surficial aquifer system has not been studied in detail. Langevin (2001) used longitudinal dispersivities (1-10 $\mathrm{m})$ and transverse dispersivities (0.1-1 $\mathrm{m}$ ) in a variable-density model for the Biscayne aquifer in Miami-Dade County. In a model of a brackish-water plume for the Biscayne aquifer in Miami-Dade County, Merritt (1996) used longitudinal and transverse dispersivities of 76 and $0.03 \mathrm{~m}$, respectively. Kwiatkowski (1987) used 1.5 and $0.15 \mathrm{~m}$ for longitudinal and transverse dispersivities, respectively, in a saltwater intrusion model of the Deering Estate in Miami-Dade County. Dispersivity estimates are likely based on the size of the area considered (Gelhar, 1986), with larger model areas having higher dispersivity values. Dispersivity in the lower part of the surficial aquifer system has not been studied.
Because the surficial aquifer system is a karst system, porosity can vary substantially between areas. Values of whole core porosity from laboratory measurements range from 0.37 to 0.48 for the Biscayne aquifer and the lower part of the surficial aquifer system in Broward County (Fish, 1988). Other values from laboratory tests on drilled cores range from 0.059 to 0.506 in the Biscayne aquifer in Miami-Dade County (K.J. Cunningham, U.S. Geological Survey, written commun., 2003). Additionally, values of vuggy porosity for cores range from 0 to 0.50 (K.J. Cunningham, U.S. Geological Survey, written commun., 2003). Merritt (1996) used a porosity value of 0.20 in the saltwater intrusion model of southern Broward County. Langevin (2001) also used a porosity value of 0.20 for a regional model of the Biscayne aquifer in Miami-Dade County. 


\section{Hydrologic Stresses}

Movement of the saltwater interface can occur in response to water-table fluctuations that reflect changes in hydrologic stresses. For example, saltwater intrusion is often attributed to lowering of the water table, which can be caused by decreases in recharge (either by drought or increased runoff due to increases in impervious areas resulting from development), ground-water withdrawals, or increased ground-water discharge to canals and the ocean. Evaluation of water-table maps is one technique that can be used to determine the dominant hydrologic stresses in a given area and identify patterns of ground-water flow. Lietz (1991) depicted the altitude of the water table in the Biscayne aquifer in Broward County during the April 1988 dry season (fig. 2). This water-table altitude is used in the following descriptions of dominant hydrologic stresses to provide a general understanding of the groundwater flow system in Broward County. Areas where contours appear to join are a result of map scale and do not reflect true hydrologic conditions. The hydrologic stresses discussed in this section are limited to those most relevant to saltwater intrusion, rainfall, evapotranspiration, well-field withdrawals, and canal stage.

During rainfall, some water (the runoff) flows directly into a surface-water body such as a lake, river, or canal where it may recharge the aquifer or drain to the ocean. Other areas have French drains that collect runoff and recharge the aquifer directly. Runoff is difficult to estimate for Broward County because of soil moisture content, soil type, land use, and lack of data. Additionally, runoff is reflected in ground-water levels and canal stages, and therefore, is not discussed in this section.

\section{Rainfall and Evapotranspiration}

The surficial aquifer system is recharged by rainfall that infiltrates through the unsaturated zone to the water table. Of the total rainfall, a portion is lost to runoff and to direct evaporation or evapotranspiration to the atmosphere. The altitude of the water table (fig. 2) indicates that the general flow of ground water is from west to east in Broward County, with ground water discharging at the coast or into canals. High topographic areas in the northern part of the county correspond with higher ground-water levels. Land-surface elevation and ground-water levels decrease toward the south and east.

Broward County receives, on average, greater than $152 \mathrm{~cm}$ of annual rainfall, ranging from 76 to $254 \mathrm{~cm} / \mathrm{yr}$. About 70 percent of the rainfall occurs during the wet season, which lasts from June to October (Jordan, 1984). The SFWMD maintains a comprehensive data base of rainfall data collected in southern Florida by Federal, State, and local agencies. Rainfall stations in the area around the Five Ash/Prospect Well Field between the Pompano and Middle River Canals in northern Broward County (fig. 7) were used to calculate monthly rainfall totals from January 1990 to December 1999. The rainfall totals for the Five Ash/Prospect Well Field area (fig. 8A) are used in the numerical model described in this report. For the 10-year period, the average rainfall exceeded $168 \mathrm{~cm} / \mathrm{yr}$, with more than 70 percent of the rainfall occurring between June and October. Rainfall is spatially variable, however, especially between coastal and inland areas of Broward County; therefore, all the rainfall stations shown in figure 7 were used for the Artificial Neural Networks (ANN) models discussed later in the report.

Evapotranspiration is the rate of water loss to the atmosphere as a result of evaporation and transpiration from plants. Evapotranspiration is a large component of the water budget and can have a substantial effect on the water table (Stephens and Stewart, 1963). During1996-97, evapotranspiration rates in the Everglades ranged from about $107 \mathrm{~cm} / \mathrm{yr}$ in an area where water levels were below land surface most of the year to about $145 \mathrm{~cm} / \mathrm{yr}$ over an open-water area (German, 2000). The maximum evapotranspiration rates used by Merritt (1996), shown below, for a calibrated regional flow model of MiamiDade County also were used in the representative model of Broward County for the current study.

\begin{tabular}{|l|l|}
\hline \multicolumn{1}{|c}{ Month } & $\begin{array}{c}\text { Maximum } \\
\text { evapotranspiration rate } \\
\text { (centimeters per day) }\end{array}$ \\
\hline January & 0.20 \\
\hline February & .28 \\
\hline March & .36 \\
\hline April & .43 \\
\hline May & .46 \\
\hline June-October & .53 \\
\hline November & .30 \\
\hline December & .28 \\
\hline
\end{tabular}

\section{Well-Field Withdrawals}

Ground-water withdrawals from the Biscayne aquifer are the sole source of potable water in Broward County and the major source of agricultural irrigation. The effects of pumping can be seen as cones of depression centered at municipal well fields (fig. 2). The upconing of saline ground water from the lower part of the surficial aquifer system is thought to occur beneath some of the well fields. Lateral saltwater intrusion also has been observed as a result of well-field pumping (Dunn, 2001). From 1996 to 1999, well-field withdrawals in Broward County increased from 890,000 to $950,000 \mathrm{~m}^{3} / \mathrm{d}$ (235 to $251 \mathrm{Mgal} / \mathrm{d}$ ) (South Florida Water Management District, 2002). The Five/Ash Prospect Well Field, which is the largest well field in Broward County, withdrew an average of 160,000 m³/d or $42 \mathrm{Mgal} / \mathrm{d}$ (fig. 8B) between 1990 and 1999.

\section{Canal Stage}

The effect of canals on the water table is illustrated by the altitude of the water table in figure 2. Canals can be classified into three types: gaining, losing, and crossflow (Fish, 1988). 


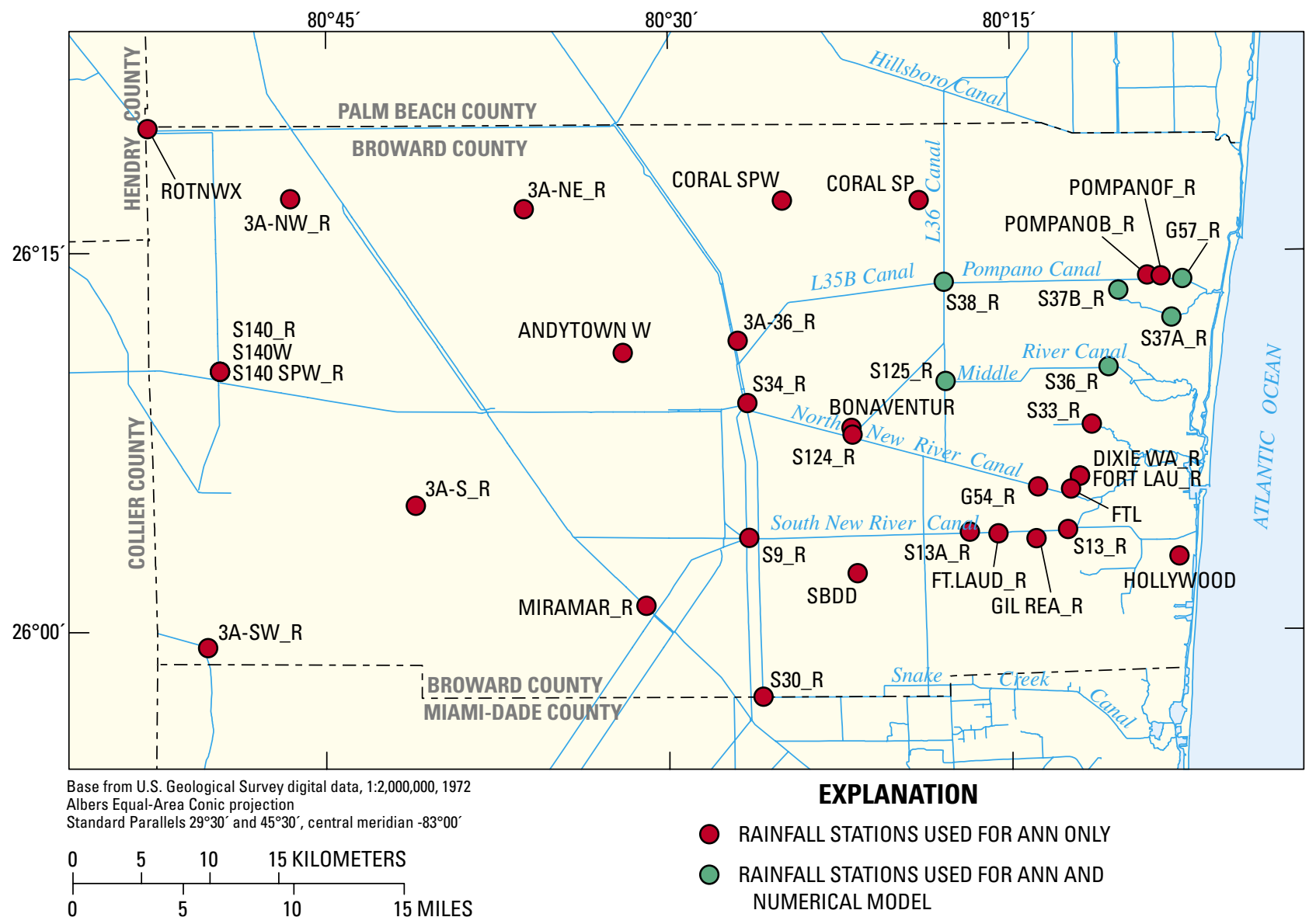

Figure 7. South Florida Water Management District rainfall stations used in the analyses. ANN is Artificial Neural Networks.

Gaining canals drain water from the aquifer and lower the water table, whereas losing canals recharge the aquifer and raise the water table. A crossflow canal allows water to flow through or beneath it without affecting the aquifer. A canal classification can change during the year depending on hydrologic conditions and water management. In some instances, various sections of a canal may be classified differently if conditions vary between sections of the canal reach, such as at a control structure.

Canals and control structures in Broward County are used to manage water levels to: (1) prevent floods, (2) recharge the surficial aquifer system, and (3) prevent saltwater intrusion. Control structures and pumps are used to manage ground-water levels by recharging or draining the aquifer as needed. If a sufficiently high upstream stage is maintained at a control structure, the water in the upstream reach of the canal recharges the surficial aquifer system, providing water for domestic and agricultural use and preventing the landward movement of the saltwater interface. Conversely, if upstream stage is maintained at lower levels, water is drained from the aquifer providing more storage for infiltrating rainfall and thereby reducing flooding.
The opening and closing of gates and the operation of pumps in the canals can change the local water-table gradient, and therefore, change ground-water flow in an area. These manipulations are typically performed in response to rainfall or drought conditions. If gates are opened for a few hours, the ground-water gradient may change locally, but the gate openings will not affect the regional ground-water flow. Gates opened for a long period of time, however, can affect regional flow gradients. If the overall inland head is lowered, the potential for saltwater intrusion can increase.

\section{Saltwater Intrusion in the Biscayne Aquifer}

Saltwater intrusion affects the Biscayne aquifer through several processes. Saltwater intrusion can occur when saline water (1) moves inland from the sea in a process known as lateral saltwater intrusion; (2) moves upward from the lower part of the surficial aquifer system by upconing, defined as the upward movement of the saltwater interface beneath a well field in response to lowered head; or (3) moves downward by leakage from the downstream reach of a tidal canal. 

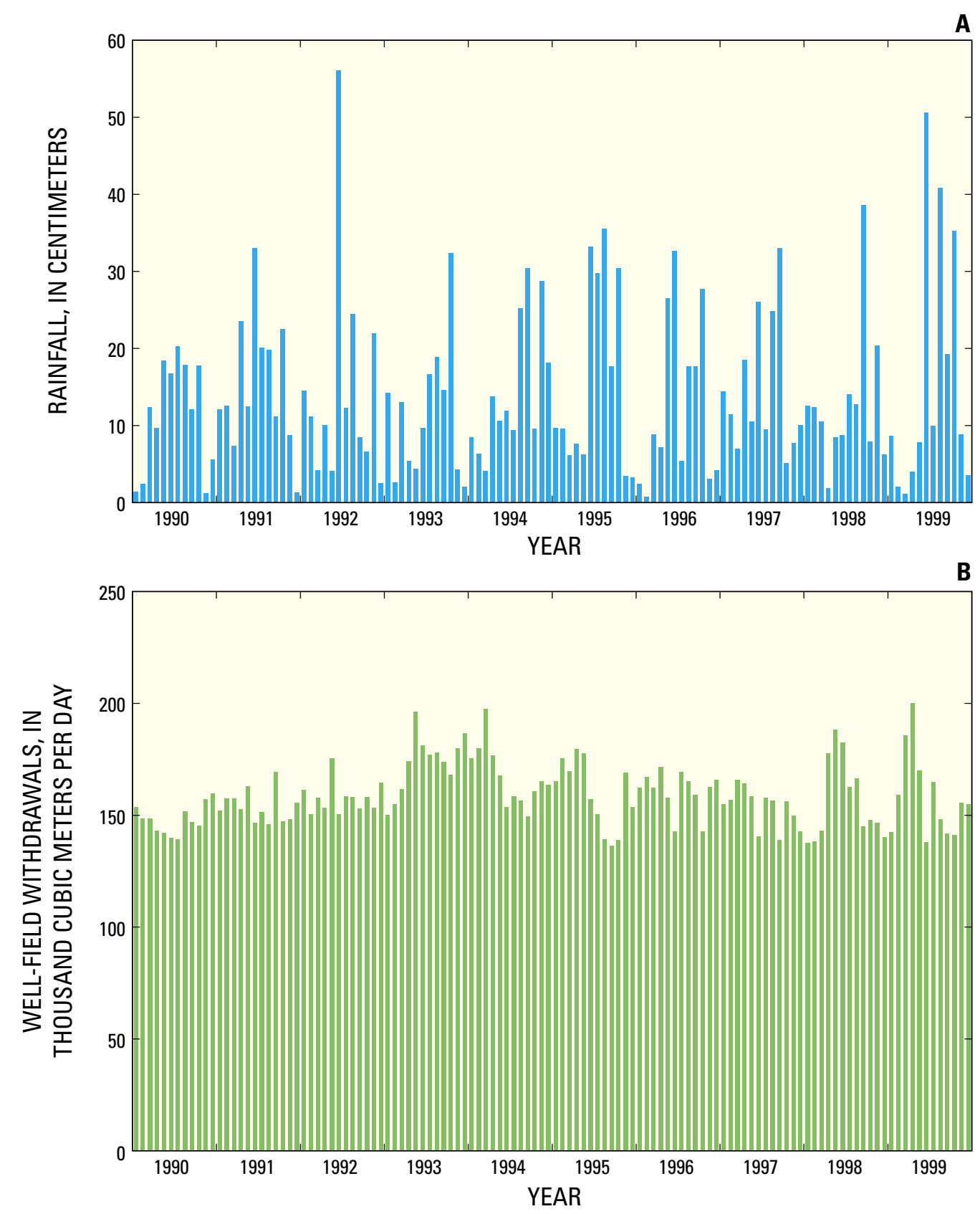

Figure 8. (A) Monthly rainfall totals and (B) withdrawals at the Five Ash/Prospect Well Field area in Broward County, 1990-99.

Prior to development in Broward County, some water flowed from the Everglades eastward to the Atlantic Ocean through a few large natural surface-water drainage features that have since been dredged to create the North New River Canal and the Middle River Canal (fig. 1). Ground-water flow was altered when these and other canals and pumps were constructed to drain areas along the southeastern coast of Florida for urban development. As the wetlands in Broward County were drained, ground-water levels declined, groundwater flow toward the Atlantic Ocean decreased, and the saltwater interface moved inland. This process increased the risk of well-field contamination by saline ground water. In response to this concern, the previously mentioned control structures (fig. 1) were built to raise water levels along inland parts of canals, increase the hydraulic gradient toward the coast, and decrease inland flow of saltwater from the ocean.

Efforts to manage water resources and evaluate saltwater intrusion typically focus on the inland edge or toe (fig. 9) of the saltwater interface. The $250-\mathrm{mg} / \mathrm{L}$ line of equal chloride concentration normally serves as a boundary of interest 


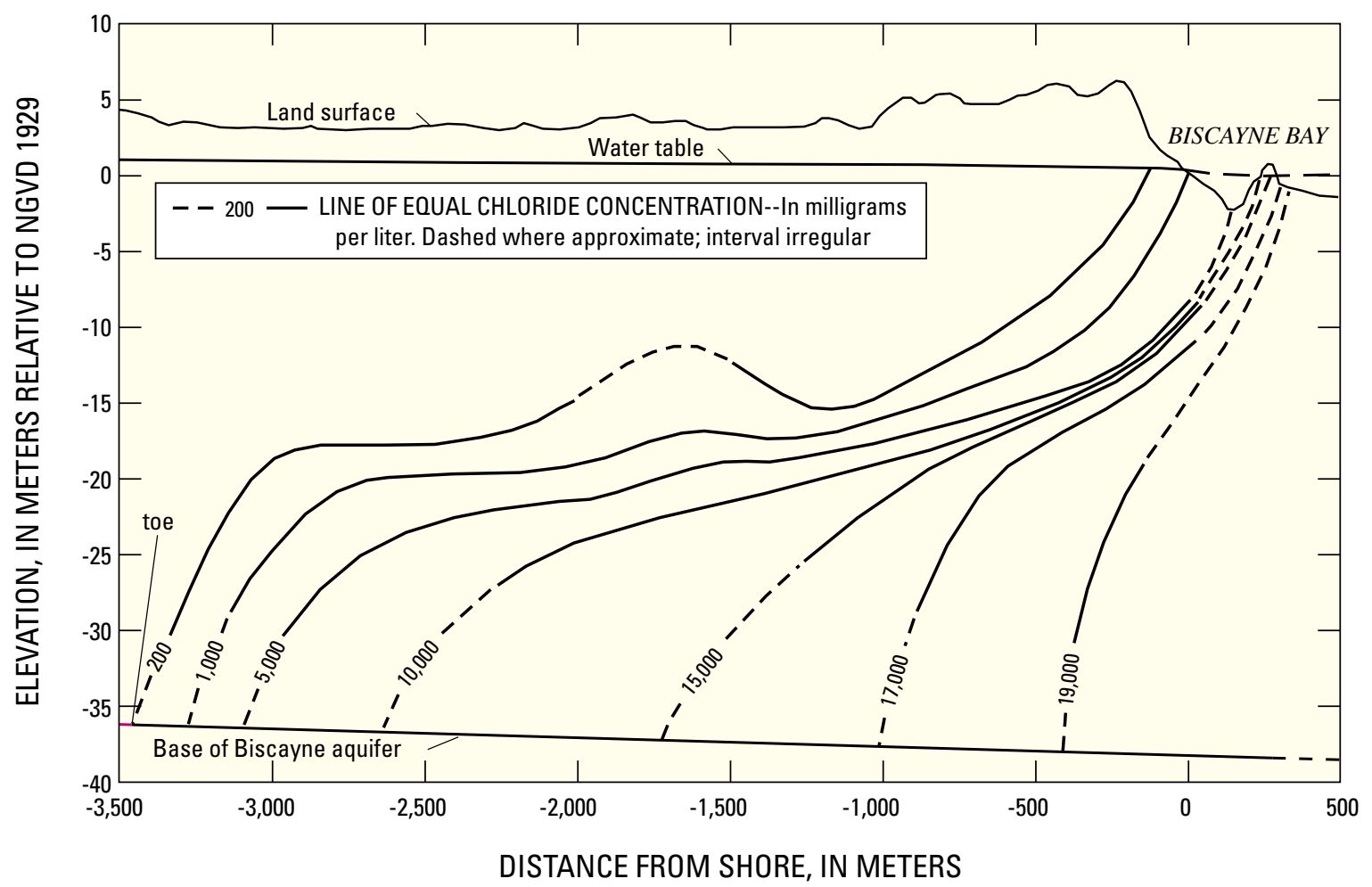

Figure 9. Lines of equal chloride concentration and toe location in the Silver Bluff area, Miami-Dade County, Florida, November 2, 1954 (modified from Kohout, 1964).

because this concentration is the U.S. Environmental Protection Agency (1977) secondary maximum level for drinking water. Inland movement of the $250-\mathrm{mg} / \mathrm{L}$ line of equal chloride concentration can threaten coastal well fields. Other definitions, however, based on analytical methods or salinity concentrations, have been used by various researchers. The approximate location of the toe, or inland extent of saltwater intrusion, was mapped for Broward County in 1994 (Broward County Department of Planning and Environmental Protection, 2000), Miami-Dade County in 1995 (Sonenshein, 1997), and Palm Beach County in 1997-98 (Hittle, 1999) (fig. 3). The inland extent of saltwater intrusion is generally seaward or just inland of coastal control structures in Broward County; therefore, these structures appear to help prevent saltwater intrusion to some extent. Before urban development, however, the interface was probably much closer to the coast. The saltwater interface appears to be stable in some areas of Broward County and moving inland in other areas based on historical and current data.

Water levels range from less than $0.3 \mathrm{~m}(1 \mathrm{ft})$ in southeastern Broward County to greater than $3.5 \mathrm{~m}(11 \mathrm{ft})$ in northeastern Broward County (fig. 2). Because higher water levels decrease susceptibility to saltwater intrusion, the inland extent of the saltwater interface is expected to be less in northern Broward County than in southern Broward County, which apparently is the case. Coastal saltwater intrusion, however, is greatest in central Broward County and not in the southeastern part as would be expected (fig. 2). The inland extent of saltwater intrusion in central Broward County probably is related to: (1) the location of canals and control structures, (2) the rate of saltwater intrusion in different parts of the county, and (3) the lack of stabilization of the saltwater interface. Different areas along the coast of Broward County were analyzed to validate these assumptions.

During this study, data compiled from various wells in Broward County (fig. 10) were grouped into two geographic areas: (1) Oakland Park area near Five/Ash Prospect Well Field and (2) southern Broward near the 3A Well Field. The history of saltwater intrusion in these two areas is discussed below.

The Five Ash/Prospect Well Field near Oakland Park (fig. 11) pumped about $160,000 \mathrm{~m}^{3} / \mathrm{d}$ in 1999 . Although this pumpage rate is high, chloride concentrations have been relatively stable since the early 1980's as indicated in figure 12 . The well field is farther inland than most other well fields in Broward County, and the canal system has several control structures that maintain water levels in the Oakland Park area (fig. 2). Between the Pompano and Middle River Canals, smaller channels route surface water and recharge the area surrounding the Five Ash/Prospect Well Field. The extent of saltwater intrusion in the Oakland Park area is slightly farther inland than in Pompano Beach or Deerfield Beach (fig. 2). 


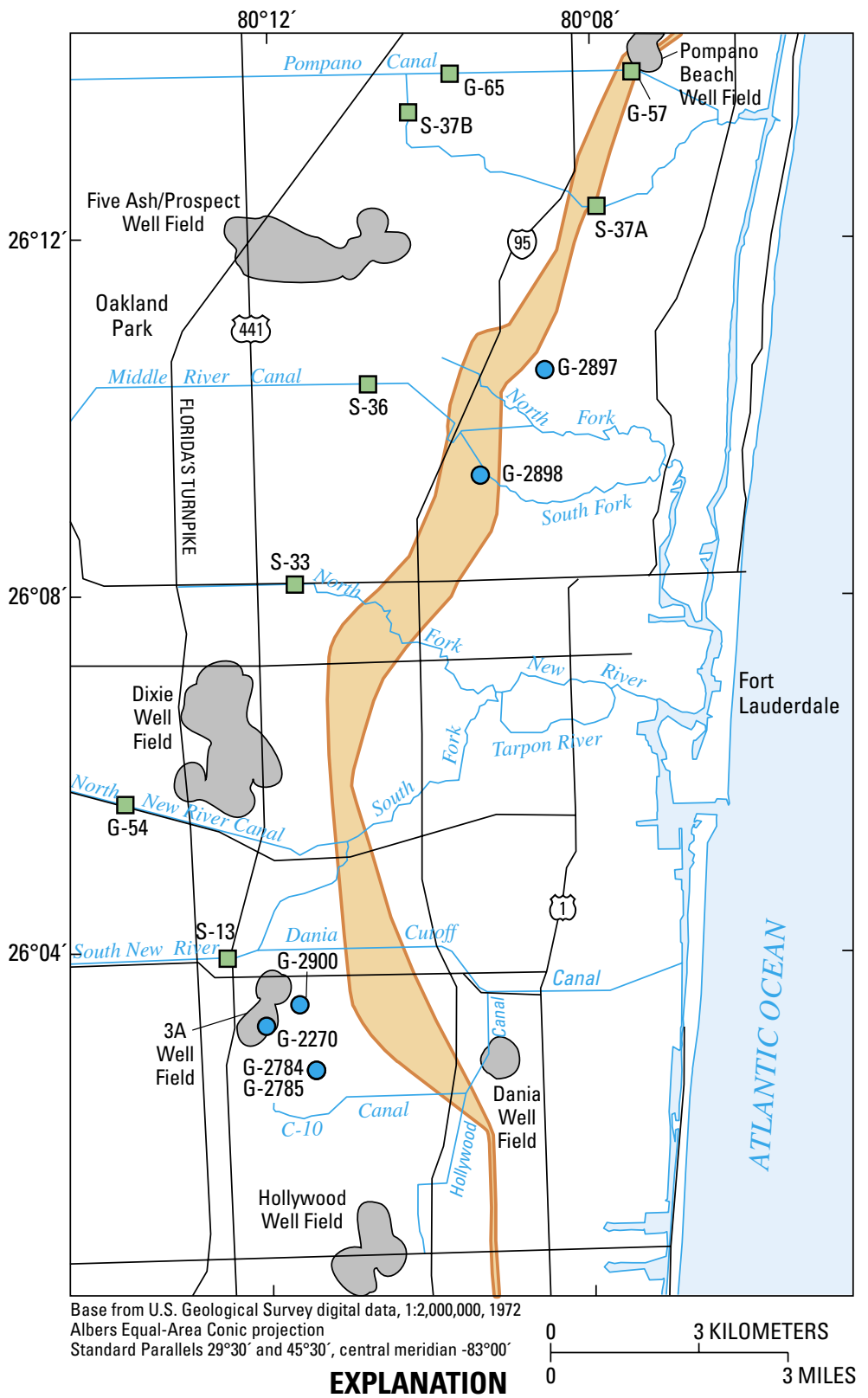

APPROXIMATE POSITION OF SALTWATER INTERFACE (Broward County

Department of Planning and Environmental Protection, 2000)

G-2270O CONTINUOUS MONITORING WELL AND NUMBER

S-13 CONTROL STRUCTURE AND NUMBER

Figure 10. Position of the saltwater interface and location of selected wells used for continuous monitoring in eastern Broward County. 


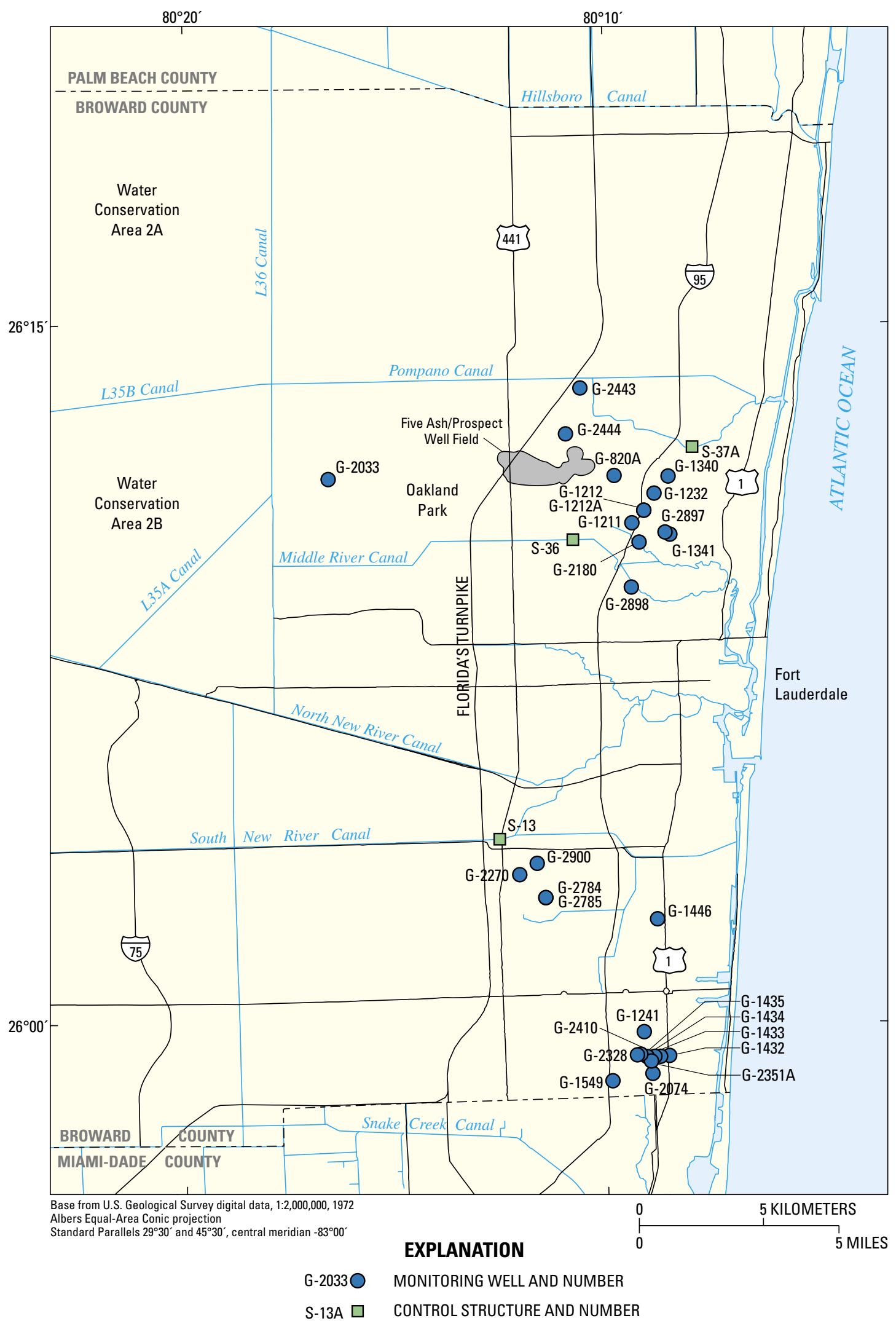

Figure 11. Location of all wells used in the study for data collection or interpretation. 


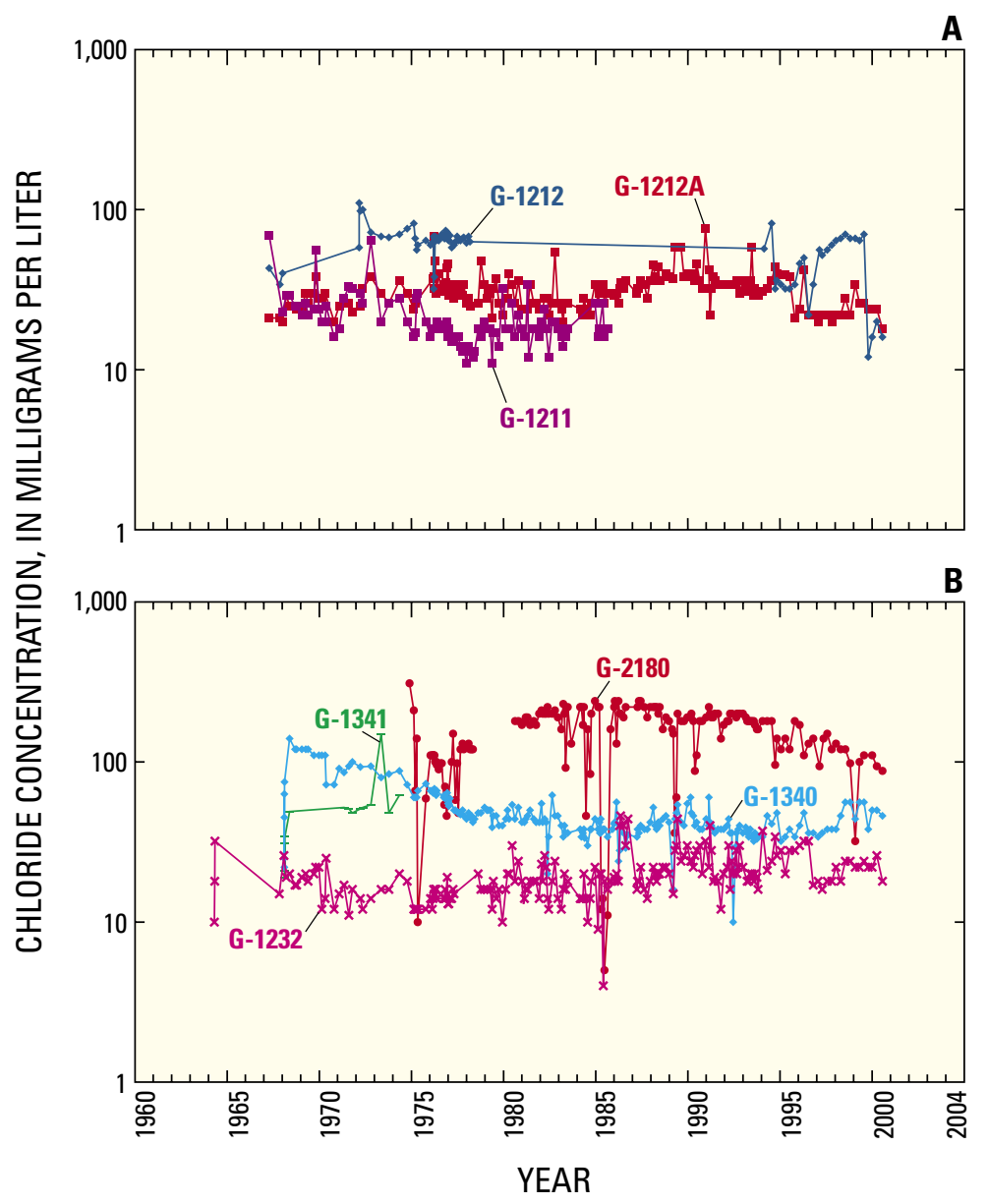

Figure 12. Ground-water chloride concentrations in the Oakland Park area, 1964-2000. Well locations are shown in figure 11.

This possibly results from structure S-36 being farther inland than structures S-37A and G-57, and from slightly lower water levels in the Oakland Park area.

Saltwater intrusion in southern Broward County (Dania, Hollywood, and Hallandale) is different than that observed in the central and northern parts of the county (fig. 2). The heads in the area are lower than in any other part of Broward County, with the exception of local areas near well fields such as the
Five Ash/Prospect well field. Southern Broward County also has fewer tidal canals than other parts of the county. Saltwater, however, has not intruded as far inland in the southern part of the county as it has in the central part of the county where heads are higher. The southern area is bounded on the north by the South New River Canal, which contains structure S-13. The next major canal south of the area is the Snake Creek Canal in Miami-Dade County, which contains structure S-29 (fig. 3). 
Although structure S-13 is almost $10 \mathrm{~km}$ inland, structure S-29 is only about $2.5 \mathrm{~km}$ from the coast; the saltwater front approximately follows the path between both structures from north to south as shown in figure 3. Chloride concentrations in ground water in southern Broward County (fig. 13), however, have steadily increased since the early 1970s. This increase could mean that the saltwater interface is still responding to the drainage of the area in the mid-1900s and has not yet stabilized. Additionally, the 3A, Hollywood, and Hallandale Well Fields (fig. 2) are subject to chloride contamination. These three well fields are major water-supply sources and together pumped more than $119,000 \mathrm{~m}^{3} / \mathrm{d}$ in 1999 .

\section{Collection and Interpretation of Field Data}

The salinity monitoring network is measured or sampled on a quarterly or semiannual basis as part of the ongoing USGS salinity-monitoring program. This effort is designed to capture the regional-scale movement of the saltwater interface; however, the existing data were not spatially or temporally detailed enough for accurate model calibration. As a result, additional field data were collected from six continuously monitored wells to complement the salinity-monitoring network data to examine short-term variations in groundwater salinities and heads. This short-term monitoring was designed to measure influences on the saltwater interface, such as tides and individual rainfall events, which helped quantify important aquifer properties and improve the accuracy of the variable-density model. Long-term changes of the saltwater interface also were examined by analyzing daily averages of the continuously monitored data.

Water-level and ground-water salinity data recorded at selected monitoring wells were used to relate canal stage and ground-water levels to saltwater intrusion. Borehole equipment was used to record water levels and fluid conductivity at 15-minute intervals in five existing wells. Additionally, water levels were recorded in a shallow freshwater well near one of these wells. Changes in salinity at the bottom of a well was assumed to indicate movement of the saltwater interface. Borehole induction logs compiled by the USGS from wells in the salinity monitoring network were used to estimate the approximate depth of the saltwater interface by noting the depth in the log at which conductivity increased.

Additionally, water-level data collected during the 1990s at wells G-820A, G-2033, G-2443, and G-2444 (fig. 11) were compared with simulated water levels.

\section{Well Selection and Continuous Monitoring}

A three-step process was used to select ground-water wells for continuous monitoring in Broward County. Six initial criteria were used in step 1 to select 17 wells from more than 60 available candidates. Step 2 involved visiting each of these wells to determine whether they met three additional criteria. Step 3 involved revisiting the 12 remaining candidate wells to determine if the 2 final criteria were met. Six wells eventually were selected for continuous monitoring.

The following criteria and the corresponding rationale were used in step 1 to select 17 candidate wells from the existing wells:

- Wells near the coast-Monitoring wells had to be located within the freshwater/saltwater transition zone for fluid conductivity monitoring to be meaningful.

- Wells within $4 \mathrm{~km}$ from canals-Monitoring wells close to canals were used to establish the relation between canal stages and movement of the saltwater interface.

- Wells within $4 \mathrm{~km}$ from control structures-Monitoring wells near control structures were used to determine the effects that structure openings had on the movement of the saltwater interface.

- Fully cased wells with open-hole or short-screened interval-Fully cased wells were required to ensure data reliability and eliminate the possibility for interwell flow and ambiguous data.

- Wells open to the Biscayne aquifer-Wells had to be located within the highly permeable aquifer for shortterm data to show changes in fluid conductivity.

- Wells open to the most inland part of the freshwater/saltwater transition zone (chloride concentrations between 250 and $2,250 \mathrm{mg} / \mathrm{L}$ )—Monitoring wells in areas where the saltwater interface is most likely to show movement. The $250-\mathrm{mg} / \mathrm{L}$ chloride concentration is the upper limit for potable water, and therefore, of critical concern to water managers.

Step 2 involved visiting sites to: (1) determine the ease of instrumenting the well, (2) verify that the saltwater interface had been penetrated, and (3) determine well casing depth. Photographs were taken to determine whether a well could be instrumented with the equipment needed for data collection. Chloride samples were collected from each well using a Kemmerer sampler to verify that current chloride concentrations were within the desired range. Borehole video cameras were used in selected wells to inspect for casing breaks, leaks, and potential monitoring problems. Five wells were eliminated because of casing breaks or an inability to house the monitoring equipment.

The third step of the well selection process involved revisiting the 12 remaining sites to determine if data were reproducible and also to verify whether a monitoring well had good connectivity with the aquifer by performing drawdown tests at each site. The chloride samples collected from this visit were compared with each other and with those from the previous visit to determine reproducibility. Wells having the greatest chloride data reproducibility were considered ideal for monitoring and less likely to have well casing leaks. 


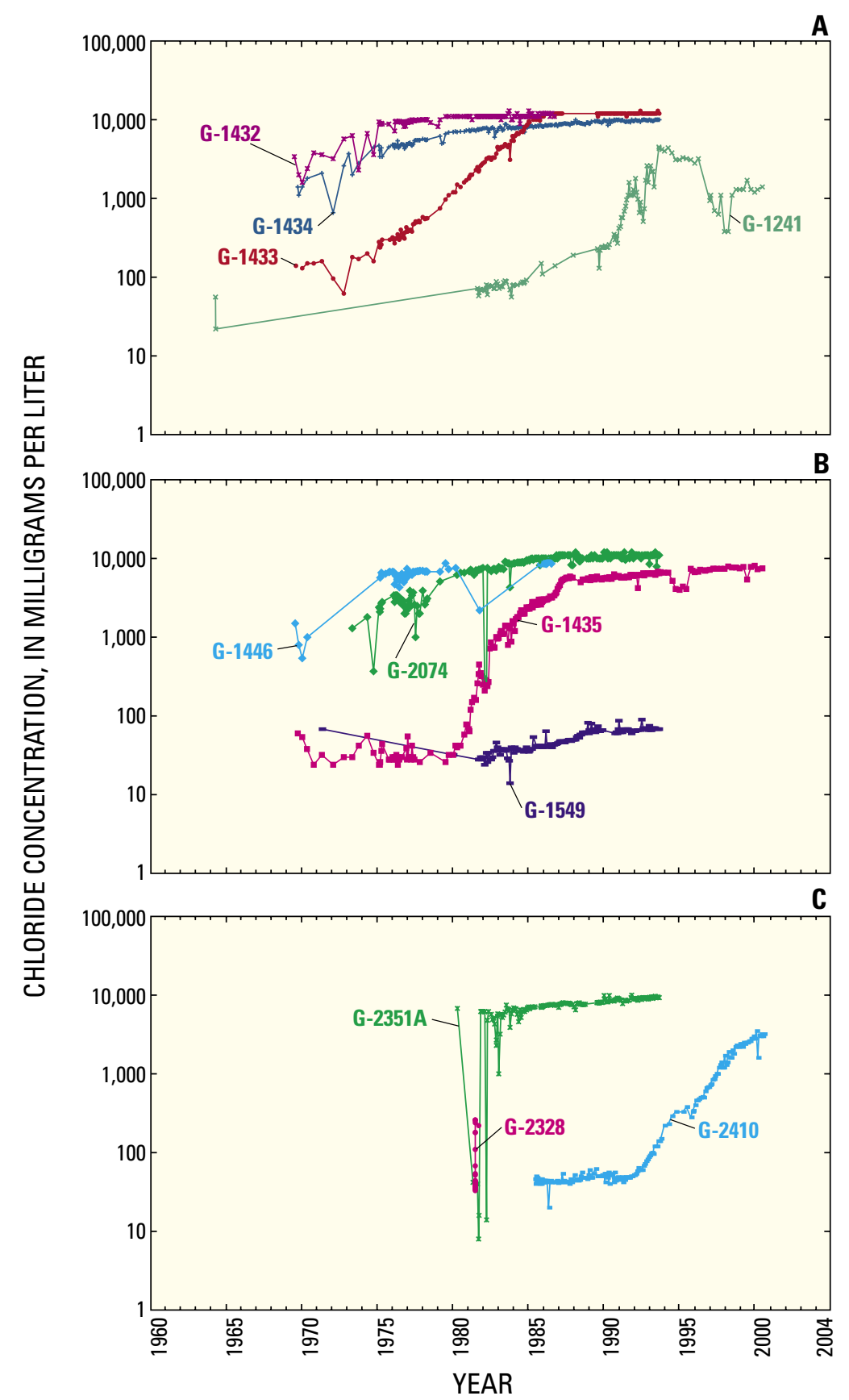

Figure 13. Ground-water chloride concentrations in southern Broward County, 1964-2000. Well locations are shown in figure 11.

The 12 remaining wells also were pumped to check recovery time. Three to five well volumes were pumped from each well, and the length of time for the well to recover was measured. Short recovery time indicated good connectivity between the well and aquifer and that the well was open in a permeable zone of the Biscayne aquifer. For example, if a well recovered within $0.3 \mathrm{~m}$ of the original water level in less than 5 minutes, the connection was considered good between the well and the aquifer. If a well recovered between 5 and 30 minutes after pumping, the connection was considered moder- ately good. If recovery time was greater than 30 minutes, the connection was considered poor (or the well was open in a low-permeability zone) and the well was not considered for monitoring.

On the basis of the three-step selection process, six wells at five sites were selected for continuous monitoring in eastern Broward County (fig. 10 and table 1). Two probes were used to collect continuous 15-minute specific conductance and water-level data in the wells. A YSI-600R probe was used to collect the specific conductance data in the middle of the 
Table 1. Wells used for continuous monitoring in eastern Broward County and their distance from the nearest canal, nearest control structure, and the coast.

$[<$, less than $]$

\begin{tabular}{|ccccc}
\hline $\begin{array}{c}\text { Well } \\
\text { number }\end{array}$ & $\begin{array}{c}\text { Depth } \\
\text { (meters) }\end{array}$ & $\begin{array}{c}\text { Distance } \\
\text { from nearest } \\
\text { canal } \\
\text { (kilometers) }\end{array}$ & $\begin{array}{c}\text { Distance } \\
\text { from nearest } \\
\text { structure } \\
\text { (kilometers) }\end{array}$ & $\begin{array}{c}\text { Distance } \\
\text { from } \\
\text { coast } \\
\text { (kilometers) }\end{array}$ \\
\hline G-2270 & 54.86 & 1.5 & 1.5 & 9 \\
\hline G-2784 & 29.26 & .9 & 3 & 7.75 \\
\hline G-2785 & 59.74 & .9 & 3 & 7.75 \\
\hline G-2897 & 41.15 & .95 & 3.5 & 4.5 \\
\hline G-2898 & 36.27 & $<.1$ & 2.9 & 5.7 \\
\hline G-2900 & 35.05 & 1.1 & 1.9 & 8.1 \\
\hline
\end{tabular}

screened interval or open hole. An H-310-15 pressure transducer was used to collect water-level data and was placed a few meters below the water surface in the well. Both probes were connected to a Sutron 8400 data logger. Data were downloaded once a month, and probes were recalibrated at that time according to USGS quality assurance/quality control procedures (Lietz, 2003).

The density and total dissolved-solids concentration of the water at the base of the well were calculated from the specific conductance data to perform statistical analysis and permit comparisons to model output. The chloride concentration value in ground water from the well was calculated from the specific conductance value. Langevin (2001) developed the following equation, which was used in the present study, from specific conductance data and chloride samples collected in the Biscayne aquifer in Miami-Dade County:

$$
C l^{-}=1.10^{-6}(S C)^{2}+0.3224 \cdot(S C)-177.7,
$$

where $\left[\mathrm{Cl}^{-}\right]$is the chloride concentration, in milligrams per liter; and $S C$ is specific conductance, in microsiemens per centimeter.

Chloride concentrations were linearly converted to total dissolved-solids concentrations by assuming that seawater has a chloride concentration of $19,800 \mathrm{mg} / \mathrm{L}$ and a total dissolvedsolids concentration value of $35,000 \mathrm{mg} / \mathrm{L}$ (Parker and others, 1955). The following conversion from the total dissolvedsolids concentration to density was developed by Baxter and Wallace (1916):

$$
\rho=\rho_{f}+\mathrm{E} \cdot \mathrm{C},
$$

where $\rho$ is the density of the native aquifer water $\left[\mathrm{ML}^{-3}\right] ; \rho_{f}$ is the density of freshwater $\left[\mathrm{ML}^{-3}\right] ; E$ is a dimensionless constant having an approximate value of 0.7143 for salinity concentrations ranging from zero to that of seawater in grams per liter; and $C$ is the salinity equivalent to total dissolved-solids concentration $\left[\mathrm{ML}^{-3}\right]$. This report uses the terms "salinity" and "total dissolved solids" interchangeably because the difference between the two is considered numerically minimal.

\section{Influences on the Saltwater Interface}

This section examines the factors that affect ground-water levels and salinity in six continuously monitored wells in eastern Broward County (fig. 10 and table 1). Of the six wells, G-2270 is not included in some of the following interpretive results because well sampling procedures seemed to affect the specific conductance results. Overall, specific conductance increased about $800 \mu \mathrm{S} / \mathrm{cm}$ at well G-2270 from May 2001 to June 2002 (fig. 14). Sharp increases in specific conductance during this period coincided with monthly site visits. Based on data collected from well G-2270, pumping about three well volumes of water during site visits apparently induced saltwater intrusion around the well. Chloride concentrations did not return to concentrations recorded prior to each site visit; therefore, well G-2270 is only included in interpretations of short-term fluctuations that are less than 1 month in duration because site visits did not affect the data collection for periods of this length.

Daily averages of the continuous monitoring data were statistically analyzed to determine long-term changes in the position of the saltwater interface. In addition to the statistics, geophysical logs of three continuous monitoring wells were analyzed to determine the saltwater interface movement over time.

Well-field withdrawal data are available only as daily averages; therefore, well-field withdrawal is not considered in the discussion of the short-term effects on saltwater intrusion shown in the continuously monitored wells. Well-field withdrawal data, however, were used in the statistical analyses of daily average data from the continuously monitored wells.

Data from the continuous monitoring wells indicate complex interactions between water levels, rainfall, upstream canal stage, and control structure openings depending on the depth of the well and geographic location of the well in relation to the canal and control structure. These complex interactions are discussed in the following sections, and a hypothesis is presented for some of the interactions based on time-series graphs.

\section{Tides}

Data from the six continuous monitoring wells in eastern Broward County (fig. 15A-E) indicated that tides (fig. 15F) affect the movement of the saltwater interface and, consequently, salinity concentrations. Tide-related specific conductance fluctuations were consistently observed at wells G-2897, G-2898, and G-2900 (fig. 15A-C). Specific conductance fluctuations over a tidal cycle can range from $25 \mu \mathrm{S} / \mathrm{cm}$ (well G-2898) to almost $300 \mu \mathrm{S} / \mathrm{cm}$ (well G-2897). Specific conductance at 


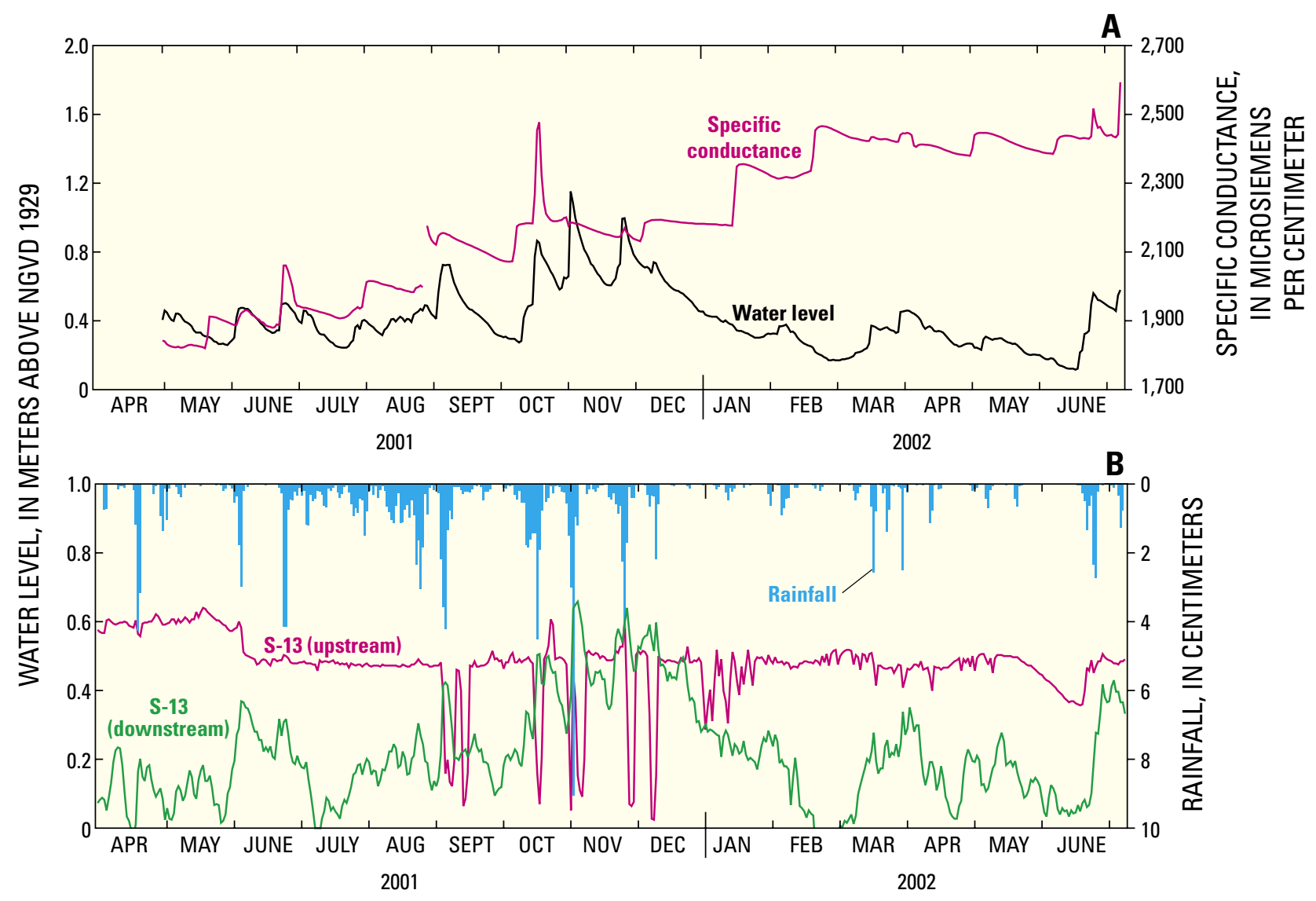

Figure 14. (A) Water level and specific conductance for well G-2270, and (B) upstream and downstream canal stage at structure S-13, and average rainfall in Broward County, April 2001 to July 2002. Record gaps are missing data due to instrumentation problems.

well G-2785 appears to be flat at the scale shown in figure $15 \mathrm{D}$ for the entire period of record. Specific conductance at well G-2270 appears to be flat at the scale shown in figure 15E for part of the record; however, after a large rainfall event (fig. $15 \mathrm{~F})$, tidally induced specific conductance fluctuations became evident at this well for more than 15 days. The increased specific conductance variation in response to increased water levels for well G-2270 was common throughout the entire period of record. The specific conductance typically decreased over time at well G-2270 between rainfall events.

Because tidal canals reflect sea-level fluctuations, waterlevel and specific conductance fluctuations in the canals can be seen in some of the continuously monitored wells. For shallow wells G-2897, G-2898, and G-2900, canal proximity seems to affect the amplitude of water-level fluctuations, but not specific conductance fluctuations. Water-level fluctuations were greater in well G-2898 (located within $100 \mathrm{~m}$ of a canal) than in wells G-2897 and G-2900 (figs. 10 and 15A-C). The amplitude of the specific conductance fluctuations at well G-2898 were smaller, however, than those for wells G-2897 and G-2900. Although G-2900 is located much farther south than wells G-2897 and G-2898 (fig. 10), the geographical position does not explain the specific conductance differences between all three wells. Wells G-2897 and G-2898 (the two closest wells geographically) showed the least similarity in terms of specific conductance fluctuations among the three wells. Differences in the amplitude of specific conductance fluctuations could result from: (1) small local variations in the Biscayne aquifer in the areas surrounding these sites, or (2) higher concentrations in the aquifer recorded at the bottom of the well, which could result in increased tidal fluctuations. For example, wells G-2900 and G-2897 have a much higher overall conductance than well G-2898, and this could be responsible for the greater amplitude in specific conductance fluctuations at these wells.

The conclusion that concentrations or hydrogeology affect amplitude of specific conductance fluctuations also is supported by comparisons of specific conductance fluctuations with depth for wells G-2897, G-2898, and G-2900. Specific conductance fluctuations do not appear to vary as a function of depth for these shallow wells. The depth of well G-2897 is greater than that of wells G-2898 and G-2900 (table 1); 


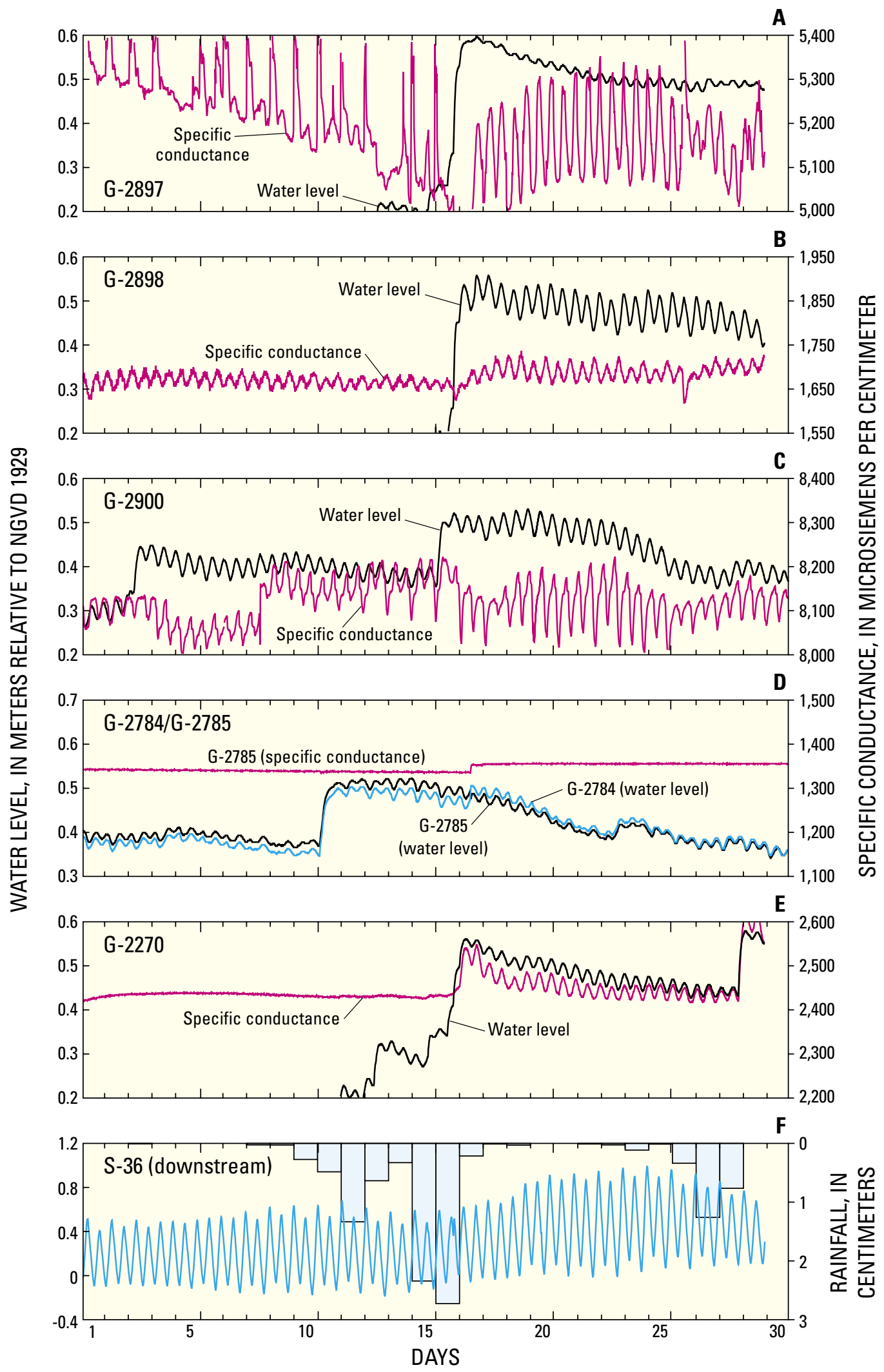

Figure 15. (A-E) Continuous 15-minute record of water-level and specific conductance data for selected monitoring wells, and (F) downstream stage and rainfall at structure $S$-36. The continuous 15 -minute stage data for S-36 is shown to illustrate tidal effects. 
however, well G-2897 has the greatest specific conductance fluctuations (fig. 15A-C). Wells G-2898 and G-2900 have similar depths, but specific conductance fluctuations are smaller in well G-2898 than in well G-2900. A marked difference in specific conductance fluctuations caused by tidal fluctuations exists between shallow and deep wells, which could be attributed to the hydrogeology in the area. Wells G-2270 and G-2785 are more than $13 \mathrm{~m}$ deeper (table 1) than shallow wells G-2897, G-2898, and G-2900.

As previously discussed, the trends in specific conductance fluctuations for the deeper wells (fig. 15D-E) are almost flat compared to that for the shallow wells (fig. 15A-C). Fish (1988) reported that the depth to the base of the Biscayne aquifer is about $60 \mathrm{~m}$ in the area surrounding wells G-2900, G-2270, and G-2785 (fig. 10). Wells G-2270 (54.86 m deep) and G-2785 (59.74 m deep) are near the base of the Biscayne aquifer where permeability is substantially lower. This lower permeability and other changes in aquifer properties at a depth of about $60 \mathrm{~m}$ could be responsible for the reduced amplitude of specific conductance fluctuations observed in the deeper wells.

The frequency and amplitude of water-level fluctuations caused by tidal fluctuations are almost identical in a shallow well and a deep well (about $1 \mathrm{~m}$ apart)—specifically, well G-2784 at a depth of $29.26 \mathrm{~m}$ and well G-2785 at a depth of $59.74 \mathrm{~m}$ (fig. 15D). One of several mechanisms could be a contributing factor. First, if the Biscayne aquifer has a high vertical hydraulic conductivity, the aquifer could be extremely well connected in the vertical direction, and tidal fluctuations could propagate downward from the tidal canals. Second, some component of the water-level fluctuation at the wells may be occurring in response to tidal pulses that propagate laterally inland from the coast. In this case, the two wells would be equally influenced by the tides because wells G-2784 and G-2785 are the same distance from the ocean. Finally, loading could cause similar water-level fluctuations for wells G-2784 and G-2785. In this case, the weight of the water moving inland near land surface during high tide propagates pressure downward through the aquifer, which creates a tidal effect at depth and compresses the aquifer matrix. When the tide recedes, the pressure is reduced, and the water levels decrease.

Fluctuations in specific conductance resulting from tidal fluctuations were observed in the saltwater interface of all wells open in the upper part of the Biscayne aquifer; however, in a well open at the base of the Biscayne aquifer and close to the lower part of the surficial aquifer system, effects of tidal fluctuations were observed in the saltwater interface after large rainfall events. The varying amplitudes of the specific conductance and water-level fluctuations in the wells are independent from the proximity to the canal and depth of the well if open in the Biscayne aquifer. These tidal fluctuations (evident from the data) could mean that the saltwater interface is moving up and down or back and forth as a result of the tides, which could have implications on future data-collection efforts. These wells are located over $4.5 \mathrm{~km}$ from the coast and show a tidal signature in their specific conductance data. Therefore, shallow wells in close proximity to the ocean will likely have a substantially greater specific conductance variation than those that are more inland. The results of monthly chloride samples collected from the bottom of a well near the ocean could differ depending on the time of day or period within the tidal cycle that the sample is collected.

\section{Rainfall and Control Structure Openings}

The saltwater interface is thought to respond to rainfall and the opening of control structures. The six wells selected for continuous monitoring are located in two different parts of Broward County (fig. 10), Oakland Park and southern Broward County. Data from each well were analyzed by graphing specific conductance and upstream and downstream canal stages for the nearest control structure. Rainfall data also are depicted in the graphs because canal stage and control structure openings typically change during hydrologic events. In southern Broward, the $\mathrm{C}-10$ is a tidal canal containing a control structure that is rarely used; therefore, S-13 structure openings are used for comparison to wells G-2784 and G-2785. The distance to the $\mathrm{C}-10$ canal is used as a reference for measurement, however, because it is closer to wells G-2784 and G-2785.

Structures S-36 in Oakland Park and S-13 in southern Broward County are managed differently. Upstream stage on the Middle River Canal is controlled by opening or closing the S-36 gate and usually is kept higher than the downstream stage. The S-36 gate can be opened during periods of high rainfall to prevent flooding upstream by allowing water to drain into the downstream part of the canal, which discharges to the ocean.

Structure S-13 on the South New River Canal is equipped with a gate and pump. The $\mathrm{S}-13$ gate operates in a manner similar to the S-36 gate; however, the pump included on S-13 is sometimes used instead of the gate, which cannot be used effectively under certain conditions. When rainfall is heavy and excessive runoff flows into the South New River Canal, the upstream side of the canal has to be drained to avoid flooding. If the ocean is at high tide, however, water levels east of structure S-13 may be higher than those west of the structure because water levels in this area are only a few meters in altitude and upstream flooding occurs easily. When upstream flooding occurs during high tide, the pump is used to move the water from the upstream side of S-13 to the downstream side, and the gate is kept closed to prevent saltwater from flowing inland along the canal, increasing saltwater intrusion and preventing flooding upstream.

\section{Response to Water-Level Changes Near Structure S-36}

This section describes the response of water level and specific conductance at wells G-2897 and G-2898 near structure S-36 to rainfall and structure openings. During a 2 -week period (September 6-19, 2001), less than $2 \mathrm{~cm} / \mathrm{d}$ of rain fell during the first week, followed by $4.5 \mathrm{~cm}$ on September 12 (fig. 16C), $2 \mathrm{~cm}$ on September 13, and trace amounts during 


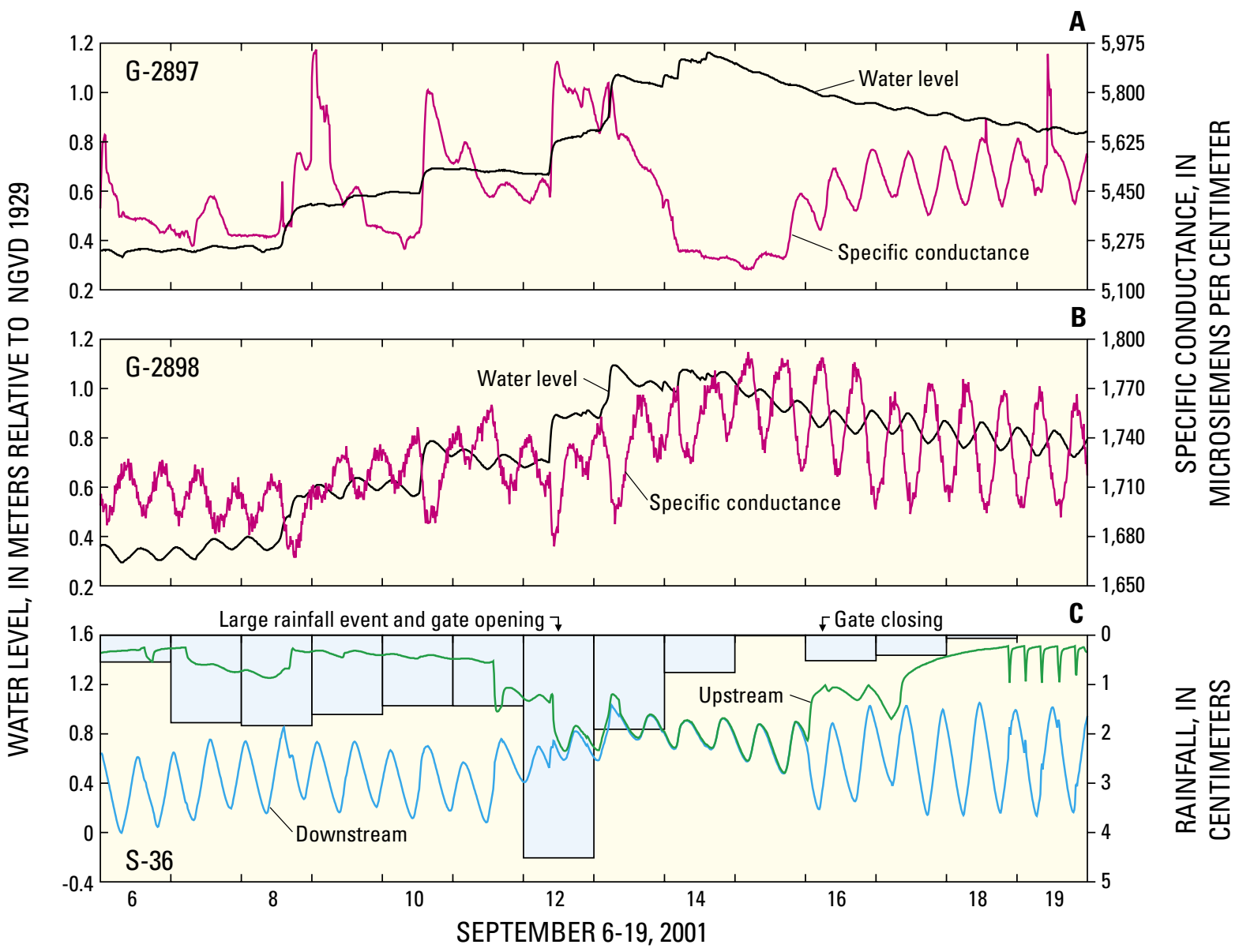

Figure 16. Specific conductance and water-level fluctuations for wells (A) G-2897 and (B) G-2898, and (C) countywide average rainfall and upstream and downstream stage at structure S-36 during September 6-19, 2001.

the rest of the second week. During the large rainfall event, the S-36 gate was opened, allowing the expected increase in water to drain downstream toward the ocean. The structure then remained open for about 3 days (September 12-15, 2001).

Water-level and specific conductance data for well G-2897 responded to the rainfall and control structure opening at structure S-36. Water levels in well G-2897 (fig. 16A) had small punctuated increases as a result of rainfall that occurred during September 6-14, 2001. After each punctuated increase in water levels, the specific conductance at the bottom of the well increased for about a day, and then gradually decreased until the next rainfall event. These increases in specific conductance with rainfall could represent loading effects resulting from the rainfall.

Water levels in well G-2897 began to decrease gradually after the rainfall decreased and the structure gate was opened. The specific conductance fluctuated widely at the bottom of well G-2897 during September 6-14, 2001. During the rainfall on September 12, the specific conductance in well G-2897 increased sharply by $500 \mu \mathrm{S} / \mathrm{cm}$. This increase in specific conductance coincided with the S-36 gate opening. After the sharp increase, specific conductance gradually decreased by about $700 \mu \mathrm{S} / \mathrm{cm}$ over the next few days, in apparent response to the rainfall.

The specific conductance and water-level fluctuations in well G-2898 are affected greatly by tides (fig. 16B-C); response to rainfall and structure openings is more difficult to discern for well G-2898 than for well G-2897. Well G-2898 is located much closer to the Middle River Canal and slightly closer to structure S-36 than well G-2897 (fig. 10). The water level in well G-2898 seemed to respond to the rainfall during September 6-14, 2001, with increases in water levels (fig. 16B). Water levels in well G-2898 gradually decreased after rainfall began to diminish on about September 14. Specific conductance in well G-2898 increased in response to the September 12 rainfall, and tidal fluctuations were more pronounced. The large rainfall event (September 12) apparently had a greater effect on specific conductance in well G-2898 than the previous smaller rain events; however, rainfall overall had less effect on specific conductance than tides. 
As a result, the stage change resulting from the gate opening probably affected the overall average salinity in well G-2898 after this date.

Specific conductance response to rainfall and gate openings for well G-2897 is different than for well G-2898, which could be related to the geographic location of both wells. Rainfall seems to have a greater effect on the specific conductance in well G-2897 than canal stage or gate openings, perhaps because the distances from the canal (almost $1 \mathrm{~km}$ ) and structure S-36 (more than $3 \mathrm{~km}$ ) dampen their effect. Conversely, well G-2898 is also about $3 \mathrm{~km}$ downstream from structure $\mathrm{S}-36$, but is less than $0.1 \mathrm{~km}$ from the canal. The difference in canal proximity between wells G-2897 and
G-2898 probably explains the greater effect that tides in the downstream canal have on well G-2898. Rainfall and structure openings also seem to affect specific conductance in well G-2898, but these influences are relatively small compared to tidal effects.

\section{Response to Water-Level Changes Near Structure S-13}

Structure S-13 on the South New River Canal near wells G-2270, G-2784, G-2785, and G-2900 (fig. 10) was operated differently than structure S-36 during September 6-19, 2001. When sporadic rainfall occurred during September 6-11 (fig. 17D), structure S-13 was opened and closed repeatedly to

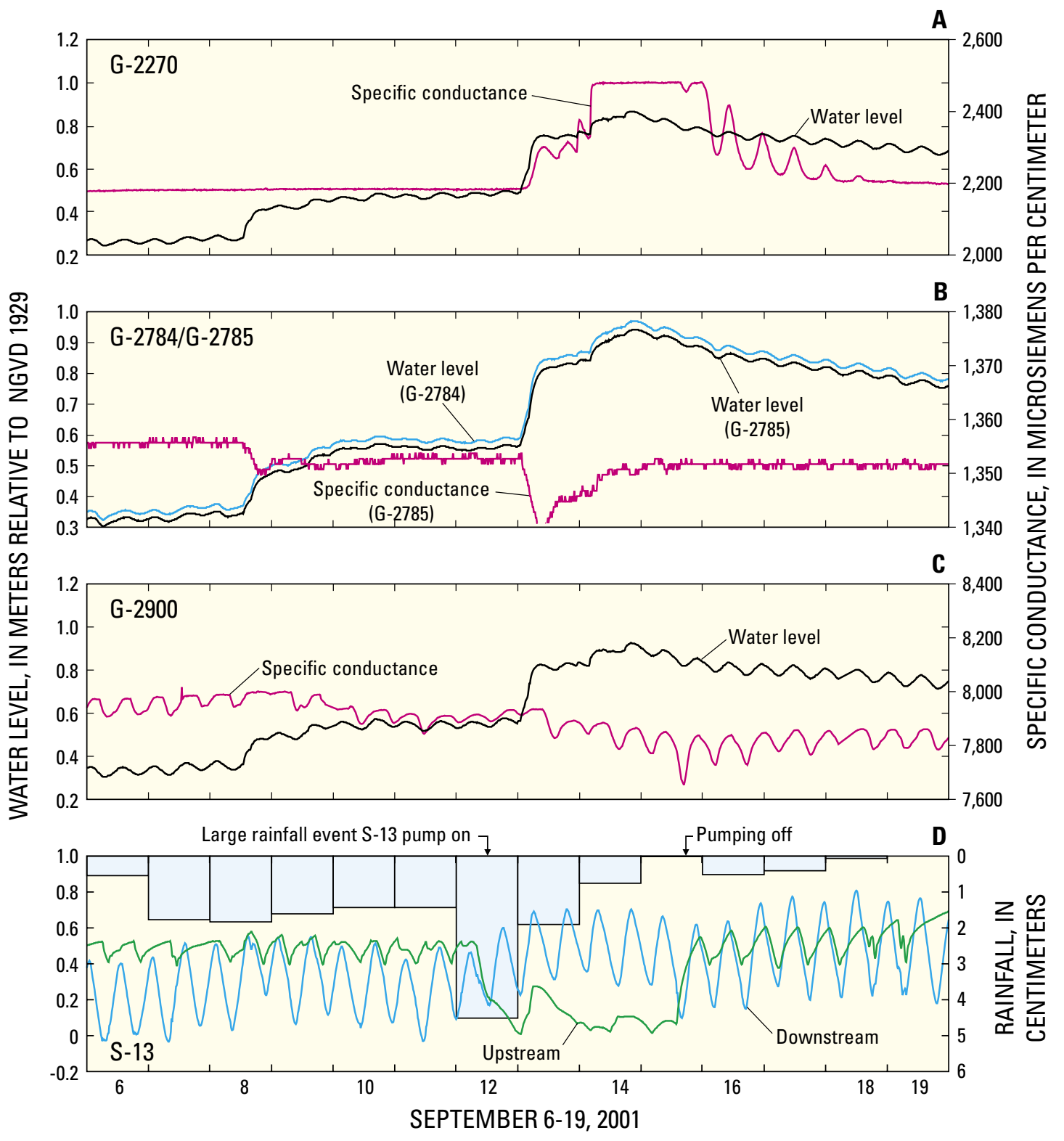

Figure 17. Specific conductance and water-level fluctuations for wells (A) G-2270, (B) G-2784 and G-2785, (C) G-2900, and (D) rainfall and upstream and downstream stage at structure S-13 during September 6-19, 2001. 
keep upstream canal stage fairly constant. After the large rainfall event on September 12, the gate was closed and the pump was operated. Consequently, canal stage was lower upstream than downstream during September 12-15 (fig. 17D).

Data collected from wells G-2784, G-2785, and G-2900 (fig. 17B-C) indicated that they seem to react similarly to rainfall events. Water levels in all three wells increased in response to the rainfall event on September 12, 2001. Specific conductance in wells G-2785 and G-2900 decreased on September 12 , probably in response to increased water levels. (Specific conductance was not collected from well G-2784.) The data also indicated that pump operation at structure S-13 during September 12-15, 2001, have little to no effect on specific conductance in either well G-2785 or G-2900.

Water-level response to rainfall was similar between wells G-2270, G-2784, G-2785, and G-2900 (fig. 17A-C). Specific conductance reacted differently, however, in well G-2270 compared to the other three wells, remaining flat during September 6-12, 2001, and increasing on September 13, 2001, after the large rainfall event. When water levels in well G-2270 rapidly increased on September 13, and then increased further at a slower rate, specific conductance also increased and remained at a constant value for about 2 days. The specific conductance in well G-2270 then decreased back to its original level. The period of elevated specific conductance may have been a time-lagged response to the pumping operation at structure $\mathrm{S}-13$. The specific conductance in well G-2270 increased about 1 day after the upstream water level dropped at structure S-13 on September 13. About 2 days after pumping ceased at structure $\mathrm{S}-13$ and upstream canal stage returned to levels observed during September 6-12, specific conductance in well G-2270 appeared to respond by returning to levels observed during September 6-13.

It appears that decreased water levels on the upstream side of structure S-13 (from pumping) cause the saltwater interface to rise. The water-level response to rainfall for the two nested wells (G-2784 and G-2785) combined with the specific conductance response in well G-2785 permit calculation of the vertical flow direction in the Biscayne aquifer. The vertical flow can be calculated by determining the equivalent freshwater head, $h_{\mathrm{f}}$, for well G-2785 using the following equation from Hubbert (1940):

$$
h_{f}=\frac{\rho}{\rho_{f}} h-\frac{\rho-\rho_{f}}{\rho_{f}} Z,
$$

where $h$ is the height of freshwater head above sea level, and $Z$ is the elevation at the measurement point [L]. The following equation is used to calculate flow in the $z$ direction (Guo and Langevin, 2002):

$$
q_{z}=-K_{f z} \frac{\mu_{f}}{\mu}\left[\frac{\partial h_{f}}{\partial z}+\left(\frac{\rho-\rho_{f}}{\rho}\right)\right]
$$

where $q_{z}$ is specific discharge, which is flow in the vertical direction, $K_{f z}$ is the hydraulic conductivity in the vertical direction, $\mu_{f}$ and $\mu$ are the viscosity of freshwater and saltwater, respectively, and $z$ is the interface depth. For many practical applications, the term $\mu_{f} / \mu$ can be considered to equal 1 because the viscosity difference between freshwater and saltwater is insignificant.

The measured water levels, calculated equivalent freshwater head, rainfall, and calculated vertical flow direction in the Biscayne aquifer from April 18 to May 1, 2002 (fig. 18A-B), indicated that ground-water flow generally is upward at wells G-2784 and G-2785. Very little rainfall occurred during this time period. Conversely, ground-water flow in the Biscayne aquifer reversed from upward to downward in response to rainfall that occurred on March 30, 2001 (fig. 18C-D). If the vertical flow direction in the aquifer changes as a result of rainfall, this downward flow could also cause seaward movement of the saltwater interface.

\section{Data Exploration with Artificial Neural Networks and Regression}

Artificial Neural Networks (ANN) models were used to analyze the effect of water levels, well-field pumpage, and canal stage on the saltwater interface using the continuous time-series data. ANN algorithms are derived from the field of machine learning called artificial intelligence. The ANN model automatically fits data from example cases developed from large data sets. A case represents one row of a table of time-series data. With time-series data, such as the monitoring well data collected for this study, cases can be composed of time-lagged data or derivatives of the data. The ANN then does pattern matching with the cases to develop a model to estimate, for example, water level or salinity concentration. The ANN method seems similar to multivariate regression and uses similar measures of goodness of fit between observed data and the ANN estimated values. Cause-and-effect relations are learned similar to multivariate regression analysis by determination of the types of data used for the ANN model, time lags of the data, and derivatives of the data that result in the best fitting ANN (P.A. Conrads and E.L. Kuniansky, U.S. Geological Survey, written commun., 2003). More information about the ANN and data mining can be found in Ripley (1994; 1996), Weiss and Indurkhya (1998), and Bishop (1995).

Paul Conrads from the USGS-WRD South Carolina District was consulted on the ANN method for this study to predict specific conductance values for four wells from differing input parameters such as water levels in the wells, pumping near the wells, and upstream canal stage. The predicted specific conductance values and observed specific conductance values were compared resulting in a measured $\mathrm{R}^{2}$ value (coefficient of determination). Sensitivities also were run to observe which parameter had the greatest effect on saltwater interface movement at each well. 

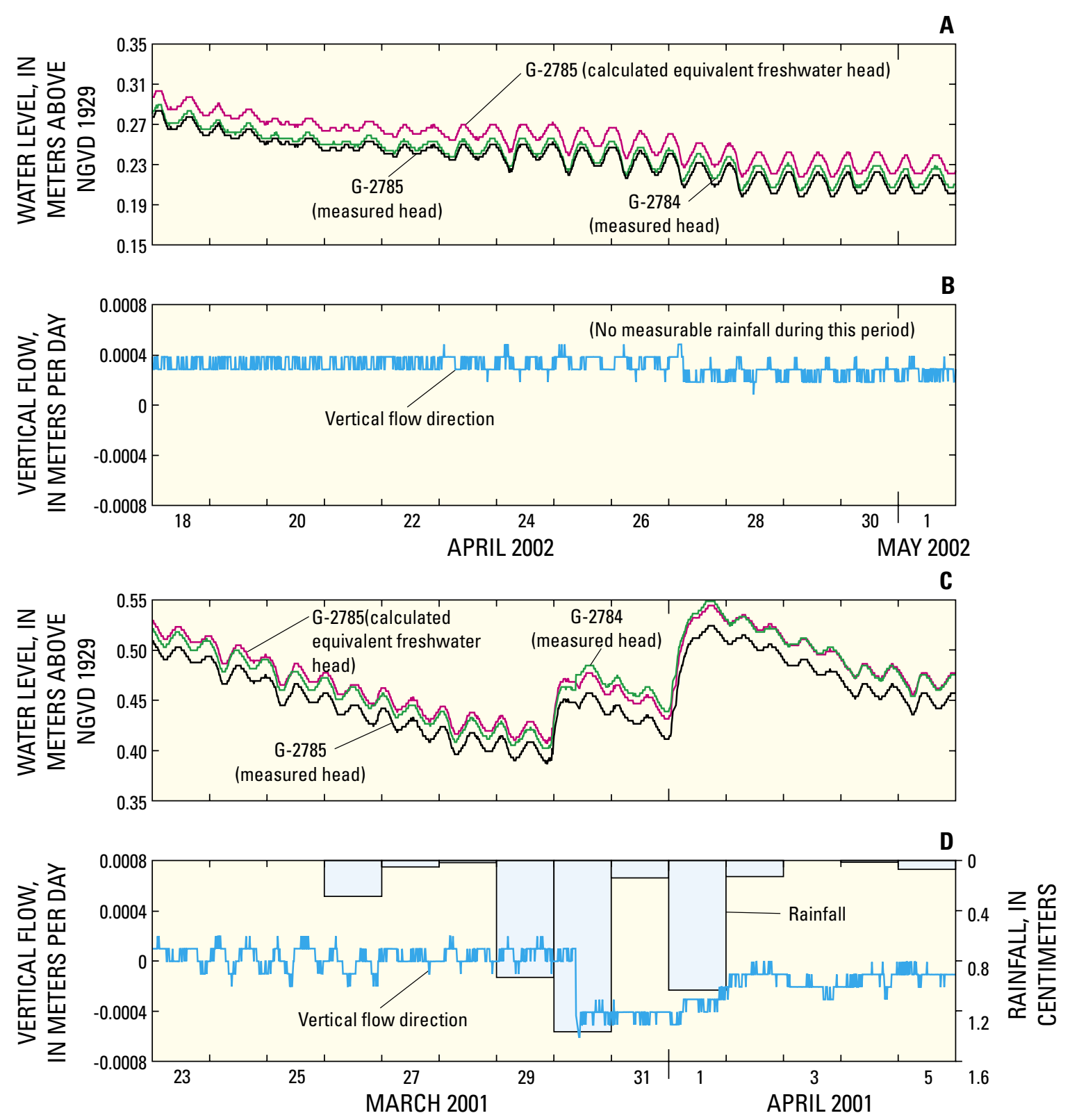

Figure 18. Water-level data for wells G-2784 and G-2785, and rainfall and vertical flow direction in the Biscayne aquifer calculated using the data from both wells during (A, B) April 18 to May 1, 2002, and (C,D) March 23 to April 5, 2001. Negative flow indicates flow into the aquifer.

Prior to the ANN analysis, water-level data were plotted in comparison with rainfall and well-field pumpage. Water levels in the six continuous monitoring wells seemed to react similarly to rainfall (fig. 19). The water levels in the wells are inversely correlated to pumping. Plots showing pumpage from the Five Ash/Prospect Well Field and water levels in well G-2898 during March 2001 to May 2002 are shown in figure 20A. A linear regression of the pumpage relative to water levels in well G-2898 (fig. 20B) has an $\mathrm{R}^{2}$ value of 0.6143 , confirming the inverse correlation between water levels and pumpage. Results indicate that ground-water levels are correlated with ground-water withdrawals and/or rainfall.

In the Oakland Park area, several parameters initially were used in the ANN model to predict the specific conductance in wells G-2897 and G-2898. These parameters are 7-day: 


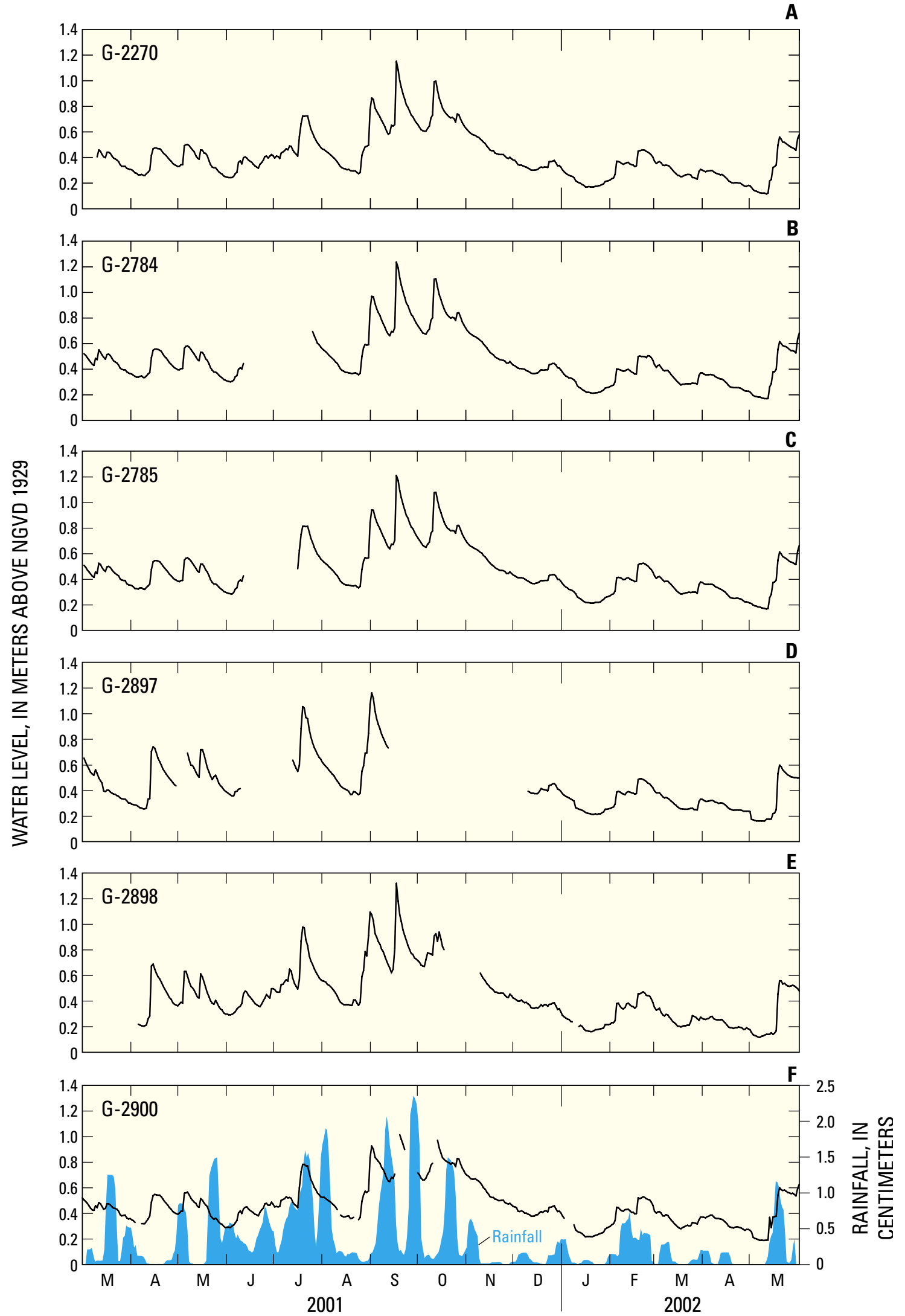

Figure 19. Daily ground-water level averages and rainfall data in Broward County, March 2001 to May 2002. Record gaps are missing data due to instrumentation problems. 


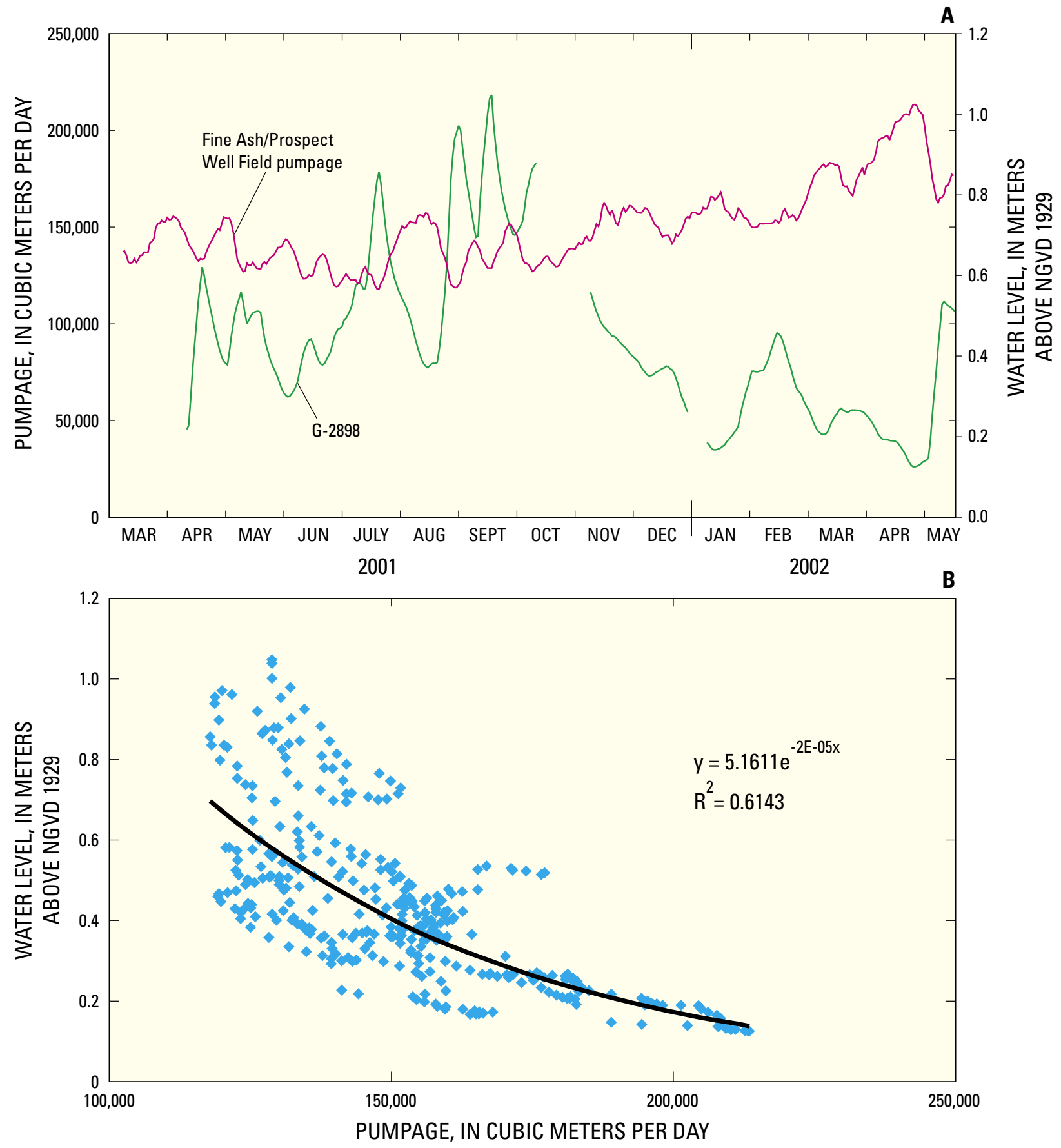

Figure 20. (A) Pumpage from the Five Ash/Prospect Well Field and average daily water levels in well G-2898, March 2001 to May 2002, and (B) linear regression of Five Ash/Prospect pumpage and well G-2898 water levels. $R^{2}$ is the coefficient of determination. Record gaps are missing data due to instrumentation problems. 
1. Moving window average of upstream stage in structure S-36,

2. Time derivative of parameter 1 (the 7-day time derivative is the upstream stage value from 7 days prior subtracted from the current upstream stage value),

3. Time lag for parameter 2 ,

4. Moving window average of the water level at the well,

5. Time derivative of parameter 4,

6. Time lag for parameter 5 ,

7. Moving window average of the pumping at the Five Ash/Prospect Well Field,

8. Time derivative of parameter 7 ,

9. Time lag for parameter 8 ,

10. Moving window average of rainfall in Broward County,

11. Time derivative of parameter 10 , and

12. Time lag for parameter 11.

After the ANN model was run, 7 of the 12 parameters were retained in the model that gave the most accurate specific conductance prediction. The ANN model predicts the specific conductance in wells G-2897 and G-2898 relatively well (fig. 21) with $\mathrm{R}^{2}$ values of 0.85 and 0.92 , respectively.

Predicting specific conductance in a well requires using a combination of parameters. The ANN model for well G-2897 seems to be most sensitive to input parameter 9, which is a lagged time derivative of the moving window average (MWA) for pumping at the Five Ash/Prospect Well Field. The next two most influential input parameters are the MWAs for upstream stage at structure S-36 and rainfall (numbers 1 and 10, respectively). In contrast, well G-2898 is most sensitive to input parameter 2, which is the 7-day time derivative of the MWA of upstream stage at structure S-36. The next two most influential input parameters for well G-2898 are the MWA of upstream stage at structure S-36 and the 7-day time lag for the time derivative of the MWA of upstream stage at structure S-36 (numbers 1 and 3), indicating that the upstream canal stage has the greatest effect on well G-2898.

The difference in results between wells G-2897 and G-2898 probably is due to the geographic locations. Well G-2898 is located beside a canal, which has the greatest effect on specific conductance in the well. Well G-2897 is farther from the canal and much closer to the Five Ash/Prospect Well Field (fig. 10); therefore, the specific conductance in well G-2897 is most sensitive to well-field withdrawal. Rainfall and canal stage also have an effect, however.

In southern Broward County, a similar set of parameters was originally used in the ANN model to make specific conductance predictions at wells G-2785 and G-2900. These parameters are 7-day:

1. Moving window average of upstream stage in structure S-13,

2. Time derivative of parameter 1 ,
3. Time lag for parameter 2 ,

4. Moving window average of the water level at the well,

5. Time derivative of parameter 4,

6. Time lag for parameter 5 ,

7. Moving window average of rainfall in Broward County,

8. Time derivative of parameter 7 , and

9. Time lag for parameter 8 .

Of these nine parameters, only four were retained in the model for well G-2785 and three for well G-2900. Well-field withdrawal parameters were not included because data from the closest well field, 3A, were incomplete. Prediction results were likely not improved because the $3 \mathrm{~A}$ Well Field is very small compared to the Prospect/Five Ash Well Field, and the cone of depression surrounding $3 \mathrm{~A}$ is minimal (fig. 2). Prediction of specific conductance for well G-2785 is poor with an $\mathrm{R}^{2}$ value of 0.25 ; however, prediction for well G-2900 is relatively good with an $\mathrm{R}^{2}$ value of 0.63 (fig. 21 ). Of the three parameters used for prediction in well G-2900, specific conductance seems most sensitive to water levels in the well, followed by the MWA of upstream stage at structure S-13 (numbers 1, 2 and 4), and finally the 7-day time derivative of the MWA of upstream stage at structure S-13.

The specific conductance was easier to predict for well G-2900, which is shallower than well G-2785 (table 1). As previously mentioned, well G-2785 is near the base of the Biscayne aquifer. Wells G-2900 and G-2897 are similar in depth and distance from the nearest canal. Well G-2900, however, is closer to structure S-13 than well G-2897 is to structure S-36 (fig. 10), and well G-2900 is not located beside a large well field. Therefore, specific conductance is sensitive to different parameters in wells G-2900 and G-2897.

Results indicated that withdrawal from a large well field, such as the Five Ash/Prospect Well Field, has the greatest effect on saltwater interface movement in the surrounding area. In order of decreasing influence, this is followed by upstream canal stage and water levels in the well and/or rainfall (water levels in the well and rainfall are closely related).

\section{Geophysical Logging}

Wells G-2897, G-2898, and G-2900 were logged multiple times during 2000-03 by the USGS, as part of the salinity monitoring network cooperative program with the SFWMD. Bulk conductivities increased at the bottom of wells G-2897 and G-2900 (figs. 22) during 2000-03, which suggests that saltwater intrusion may be increasing over time in these areas. The spike in bulk conductivity at a depth of about $23 \mathrm{~m}$ in well G-2897 could be the result of a clay layer or a high permeable zone where saltwater has intruded; however, the specific cause of the spike is unknown. 


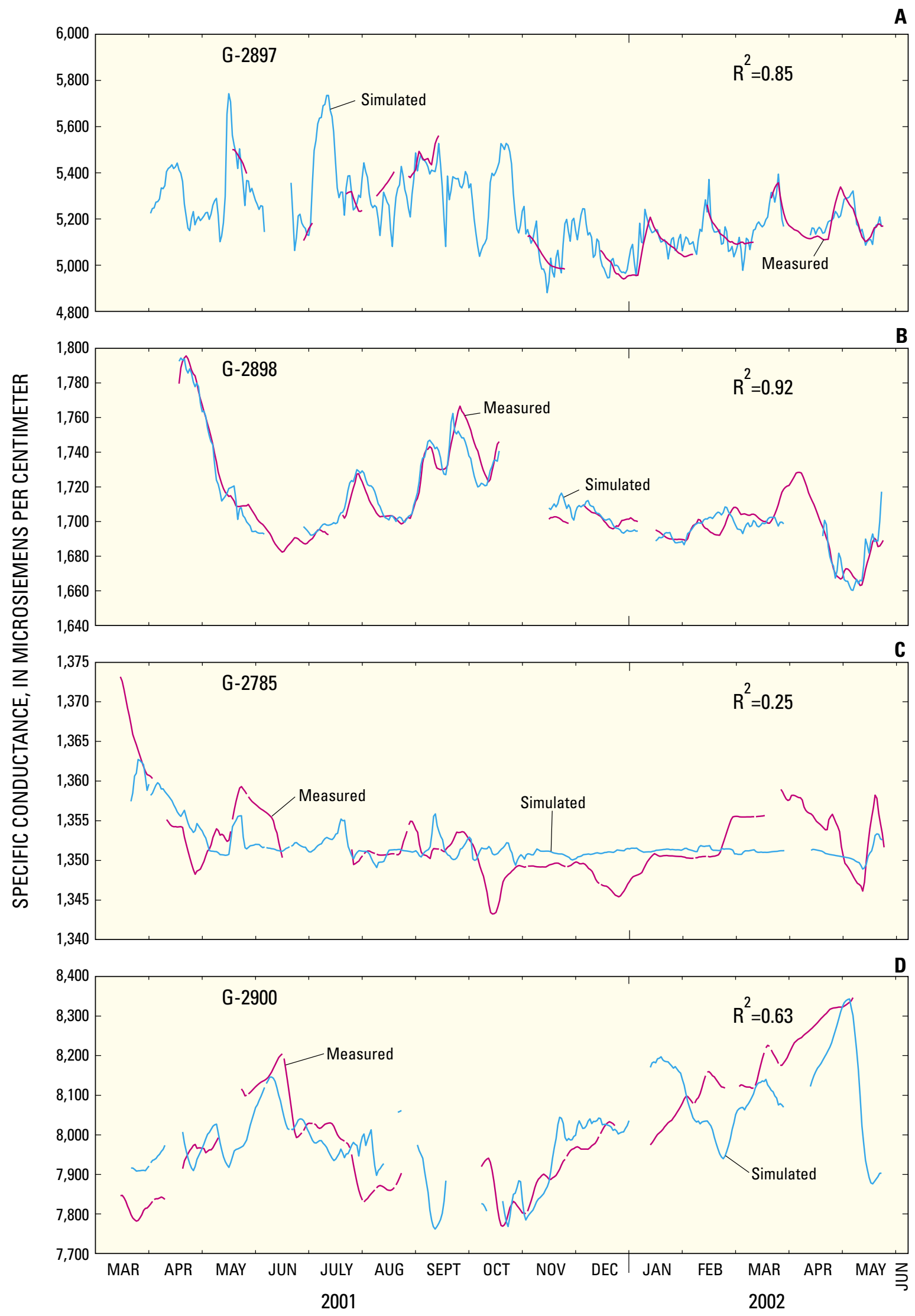

Figure 21. Measured and simulated specific conductance in wells G-2897, G-2898, G-2785, and G-2900 based on the Artificial Neural Networks (ANN) model, March 2001 to June 2002. Record gaps are missing data due to instrumentation problems. 
A

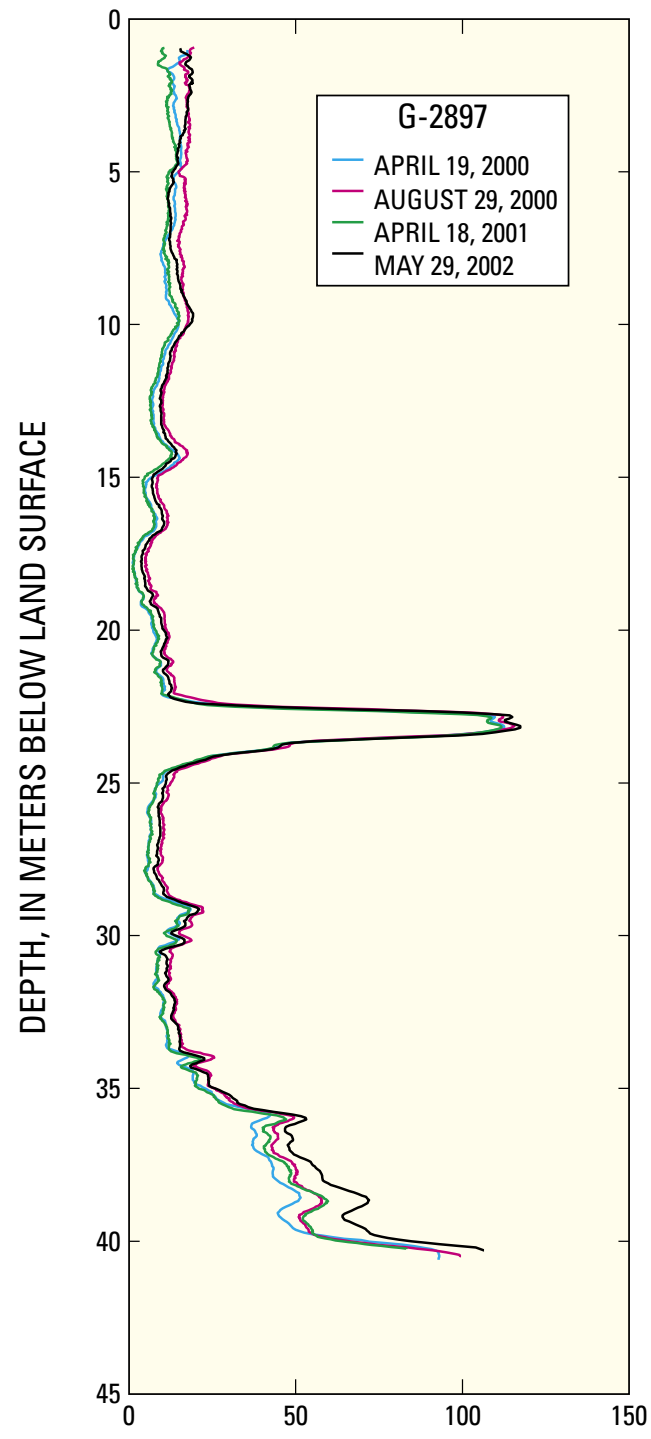

B

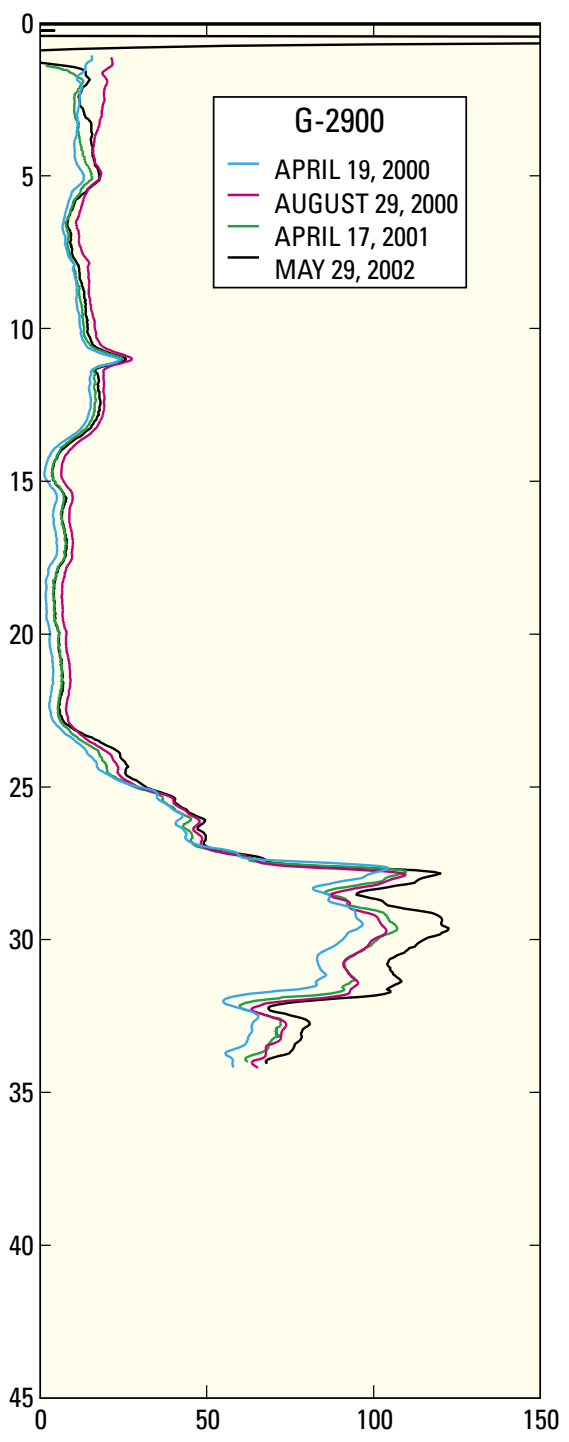

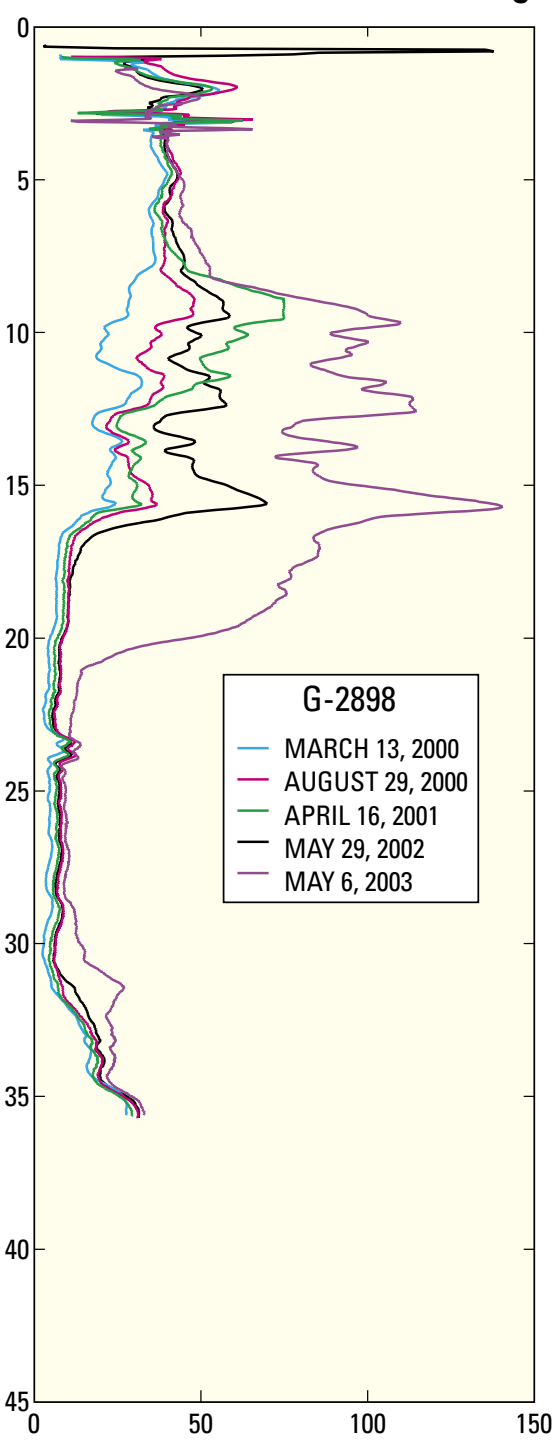

BULK CONDUCTIVITY, IN MILLISIEMENS PER METER

Figure 22. Geophysical logs of wells G-2897, G-2900, and G-2898 showing bulk conductivity with depth, 2000-03.

Well G-2898, which is directly beside a canal, had different results than the other two monitoring wells (fig. 22). Although salinity generally increased over time, the area of increased salinity was not at the bottom of the well $(36.27$ $\mathrm{m})$, but instead between 8 and $17 \mathrm{~m}$ deep. A layer of more saline ground water seems to overlie less saline ground water. This could be the result of a highly permeable zone, pumping from the Five Ash/Prospect Well Field, or leakage from the canal adjacent to well G-2898. Additionally, the upper layer of saline ground water in well G-2898 in the interval between 8 and $12 \mathrm{~m}$ in 2001 appeared to move downward in the interval between 12 and $17 \mathrm{~m}$ in 2002. This movement likely resulted from downward vertical flow of higher density saline water.

\section{Numerical Simulation of Saltwater Interface Movement in Response to Water-Level Fluctuations}

A ground-water flow and solute-transport model, developed in conjunction with a properly designed field study, can be used to effectively evaluate the relations between fluctuations in ground- and surface-water levels and movement of the saltwater interface. In this study, the numerical model was designed to represent areas in Broward County that contain a canal, a control structure, a well field, the Intracoastal Waterway, and the Atlantic Ocean. Although not calibrated 
to any specific location, the model was patterned after the coastal area near the Five Ash/Prospect Well Field and uses the normal range of existing values for the aquifer parameters. The representative model uses the variable-density flow and transport code SEAWAT to evaluate the three-dimensional relation between ground- and surface-water levels and movement of the saltwater interface in Broward County.

Because MODFLOW is such a widely used flow model, a procedure for converting a constant-density MODFLOW model into a variable-density SEAWAT model was developed. The Broward County MODFLOW model (South Florida Water Management District, 2000a) is used to illustrate the procedure, which is documented in the appendix but not discussed in this report. Although the resultant Broward County SEAWAT model is not calibrated to chloride (or salinity) concentrations, the model simulates the location of the saltwater interface at equilibrium based on the Broward County MODFLOW model water levels.

\section{SEAWAT Simulation Code}

According to Kohout (1960a), ground-water flow in coastal environments is affected by the density difference between freshwater and seawater. To simulate coastal environments and analyze tidal effects on hydrodynamic dispersion, a code is required that solves the variable-density groundwater flow and solute-transport equations. The SEAWAT code (Guo and Langevin, 2002), which is a combined version of MODFLOW (McDonald and Harbaugh, 1988) and MT3DMS (Zheng and Wang, 1998), is used to simulate the variabledensity flow patterns. The SEAWAT code utilizes MODFLOW routines to solve the following equation for variable-density flow in terms of equivalent freshwater head:

$$
\begin{gathered}
\frac{\partial}{\partial x}\left(\rho K f_{x} \frac{\partial h_{f}}{\partial x}\right)+\frac{\partial}{\partial y}\left(\rho K f_{y} \frac{\partial h_{f}}{\partial y}\right)+\frac{\partial}{\partial z}\left(\rho K f_{z}\left[\frac{\partial h_{f}}{\partial_{z}}+\frac{\rho-\rho_{f}}{\rho_{f}} \frac{\partial Z}{\partial z}\right]\right) \\
=p S_{f} \frac{\partial h_{f}}{\partial t}+\theta \frac{\partial p}{\partial C} \frac{\partial C}{\partial t}-\bar{\rho} q_{s}
\end{gathered}
$$

where $K_{f x}, K_{f y}, K_{f z}$ are the freshwater hydraulic conductivities in the three coordinate directions $\left[\mathrm{LT}^{-1}\right] ; S_{\mathrm{f}}$ is the specific storage in terms of an equivalent freshwater value $\left[\mathrm{L}^{-1}\right] ; t$ is time [T]; $\theta$ is porosity [dimensionless]; $\rho$ is the density of water entering from a source or leaving through a sink $\left[\mathrm{ML}^{-3}\right] ; C$ is the salinity equivalent to total dissolved-solids concentration $\left[\mathrm{ML}^{-3}\right]$, and $q_{s}$ is the volumetric flow rate per unit volume of aquifer representing sources and sinks $\left[\mathrm{T}^{-1}\right]$.

As flow can redistribute the solute mass, SEAWAT solves the following form of the solute-transport equation:

$$
\frac{\partial C}{\partial t}=\bar{V} \cdot(D \cdot \bar{V} C)-\bar{V} \cdot(\bar{v} C)-\frac{q_{s}}{\theta} C_{s},
$$

where $D$ is the hydrodynamic dispersion coefficient $\left[\mathrm{L}^{2} \mathrm{~T}^{-1}\right]$, $v$ is the fluid velocity $\left[\mathrm{LT}_{-1}\right]$; and $C_{s}$ is the solute concentration of water entering from sources or sinks $\left[\mathrm{ML}^{-3}\right]$.

Solute concentration is converted to fluid density with the equation of state (eq. 2). SEAWAT has options for iteratively coupling the flow and transport equations or coupling with the one time-step lag approach used in this study.

\section{Model Design}

The surface-water hydrology of eastern Broward County consists primarily of east-west canals that connect inland parts of the county with the Intracoastal Waterway. As previously mentioned, coastal control structures within the canals are often closed, restricting the flow of freshwater into the Atlantic Ocean. In many parts of Broward County, municipal well fields are located west of the saltwater interface in the areas between canals. The numerical models developed as part of this study were designed to utilize this commonly occurring hydrologic pattern. Rather than developing numerical models for each area, a representative model was developed to capture the generalized flow patterns and saltwater intrusion rates that occur in a typical area in Broward County.

Although the model is a generalized representation, field data were used to set boundary conditions and other physical characteristics of the system, and to compare with simulation results to ensure that the model is indeed representative of Broward County. In many cases, field data from the area near the Five Ash/Prospect Well Field were used in model development.

Two different temporal scales were simulated with the model. Because field data show diurnal fluctuations in water levels and specific conductance, a 1-month simulation was performed using 15-minute stress periods. This 1-month simulation, which includes tidal fluctuations at the ocean boundary, was used primarily to estimate representative values for aquifer parameters. A 10-year simulation with monthly stress periods also was performed to evaluate the long-term effects of water-level fluctuations on saltwater intrusion. The 1-month and 10-year simulations both used the same model grid, aquifer properties, and boundary types.

\section{Initial Water Levels and Salinity Concentrations}

The water levels and salinity concentrations in the model must be at dynamic equilibrium at the beginning of each simulation to evaluate changes in the model heads and salinities in response to changes from environmental stresses. If the model does not start at dynamic equilibrium, then the heads and concentrations potentially could be changing as a result of numerical stabilization as opposed to environmental stresses. A model reaches dynamic equilibrium when water levels and salinity concentrations do not change during subsequent simulations. For this study, the model was run until it reached 
dynamic equilibrium. The equilibrium heads and salinity concentrations were then used as the initial conditions in all subsequent model simulations to evaluate different environmental stresses on saltwater intrusion.

\section{Spatial Discretization}

Design of a finite-difference model grid involves a compromise between the length of computer run times and the accuracy of simulation results; finer resolution leads to less numerical dispersion, but increased run times. To increase the level of resolution for the representative model and maintain relatively short computer run times, only half of a hydrologically symmetric area was simulated (fig. 23A). A well field located midway between two canals results in a symmetric ground-water flow system. Accordingly, the model grid was designed only for the southern half.

The three-dimensional finite-difference grid (fig. 23B-C) used for the representative model consists of 15 layers; the top layer is $10.5 \mathrm{~m}$ thick, and each underlying layer is $7.5 \mathrm{~m}$ thick. The lower layers of the model grid correspond with the lower part of the surficial aquifer system. Maps showing the base of the Biscayne aquifer and the lower part of the surficial aquifer system (Fish, 1988) were used to determine these hydrogeologic features in the model. Cells in the model grid each represent a $150 \times 150 \mathrm{~m}$ horizontal area and are set as inactive below the base of the surficial aquifer system. The entire model grid encompasses $3.45 \times 22.8 \mathrm{~km}$ and contains 23 rows and 152 columns. The east-west dimension of the model $(22.8 \mathrm{~km})$ represents the approximate distance from Levee 36 (which borders the wetlands in northern Broward County) to the approximate seaward edge of the Biscayne aquifer beneath the ocean. The north-south dimension of the model $(3.45 \mathrm{~km})$ represents about half the distance between the Pompano and Middle River Canals (fig. 2).

\section{Boundary Conditions}

The boundary conditions represented by the threedimensional model consist of constant head, general head, well-field withdrawals, no flow, recharge, and evapotranspiration. Constant-head cells represent the canal and Intracoastal Waterway (on layer 1), and Atlantic Ocean (fig. 23B). The constant-head cells simulating the canal are considered a hydrologic divide. Two different constant-head values in the canal were used to represent stage above and below a saltwater control structure (fig. 23B). The constant-head cells were also assigned constant concentration values. Salinity concentrations were set at $0 \mathrm{~g} / \mathrm{L}$ for the upstream canal, 12 $\mathrm{g} / \mathrm{L}$ for the downstream canal, and $23 \mathrm{~g} / \mathrm{L}$ for the Intracoastal Waterway. These concentration values were estimated from total dissolved-solids samples collected from the canals and Intracoastal Waterway by the Broward County Environmental Monitoring Division (site numbers 5, 6, 10, 11, 36, 37, http://205.166.161.20/dpep/wqi/map/mi20102.html) and data for these sites retrieved from the U.S. Environmental Protection Agency STORET website (http://www.epa.gov/storet/) for1980-2000. Data were retrieved on August 22, 2001.

The Atlantic Ocean is represented by constant-head cells with a salinity value of $35 \mathrm{~g} / \mathrm{L}$. The head value is set equal to the downstream stage value for the canal along the southern boundary. Constant-head cells represented the ocean bottom, which was determined by using a bathymetric map (U.S. Geological Survey, 1986). Cells within the open ocean were inactive for the simulation because these ocean cells do not affect model results. About $1 \mathrm{~km}$ inland from the coast, constant-head cells were used to represent the Intracoastal Waterway in layer 1 (fig. 23B-C). The lateral boundaries on the northern and southern ends of the barrier island are simulated as no-flow boundaries because flow through the island is assumed to be in an east-west direction. No-flow cells were used for the bottom layers to represent the base of the surficial aquifer system (Fish, 1988). The general-head boundary (GHB) cells represent the hydraulic connection in the model to the Everglades wetlands. All the GHB cells have a specified total dissolved-solids concentration value of $0 \mathrm{~g} / \mathrm{L}$. The GHB cells are simulated in all active layers on the western model boundary, and head values were set equal to the upstream canal stage. Specific conductance values were set at 8,625 $\mathrm{m}^{2} / \mathrm{d}$ in the Biscayne aquifer and at $1,125 \mathrm{~m}^{2} / \mathrm{d}$ in the lower part of the surficial aquifer system. These specific conductance values were calculated using the hydraulic conductivity values and the cell dimensions.

Input values for recharge, evapotranspiration, and wellfield withdrawals also were based on field data. Recharge is estimated through model simulation by subtracting evapotranspiration from precipitation. Monthly precipitation rates are assigned to active surface cells using the Recharge package. The model calculates evapotranspiration using a maximum evapotranspiration rate and extinction depth assigned to each active surface cell using the Evapotranspiration package.

\section{Estimation of Representative Aquifer Parameters}

A 1-month tidal simulation with a tidally varying ocean boundary was performed to determine representative model values for selected aquifer parameters. The underlying concept behind this approach is that the diurnal fluctuations in water level and specific conductance, as measured in five of the six continuous monitoring wells (fig. 10), are caused by ocean tides. Representative values can be determined by adjusting parameters until simulated amplitudes from the model match the observed amplitudes. The parameters estimated as part of this procedure include horizontal and vertical hydraulic conductivities, porosity, specific yield, and transverse and longitudinal dispersivities.

Although the monitoring wells for this study are located in different parts of Broward County (fig. 10), data from all these wells were used to determine the representative aquifer 

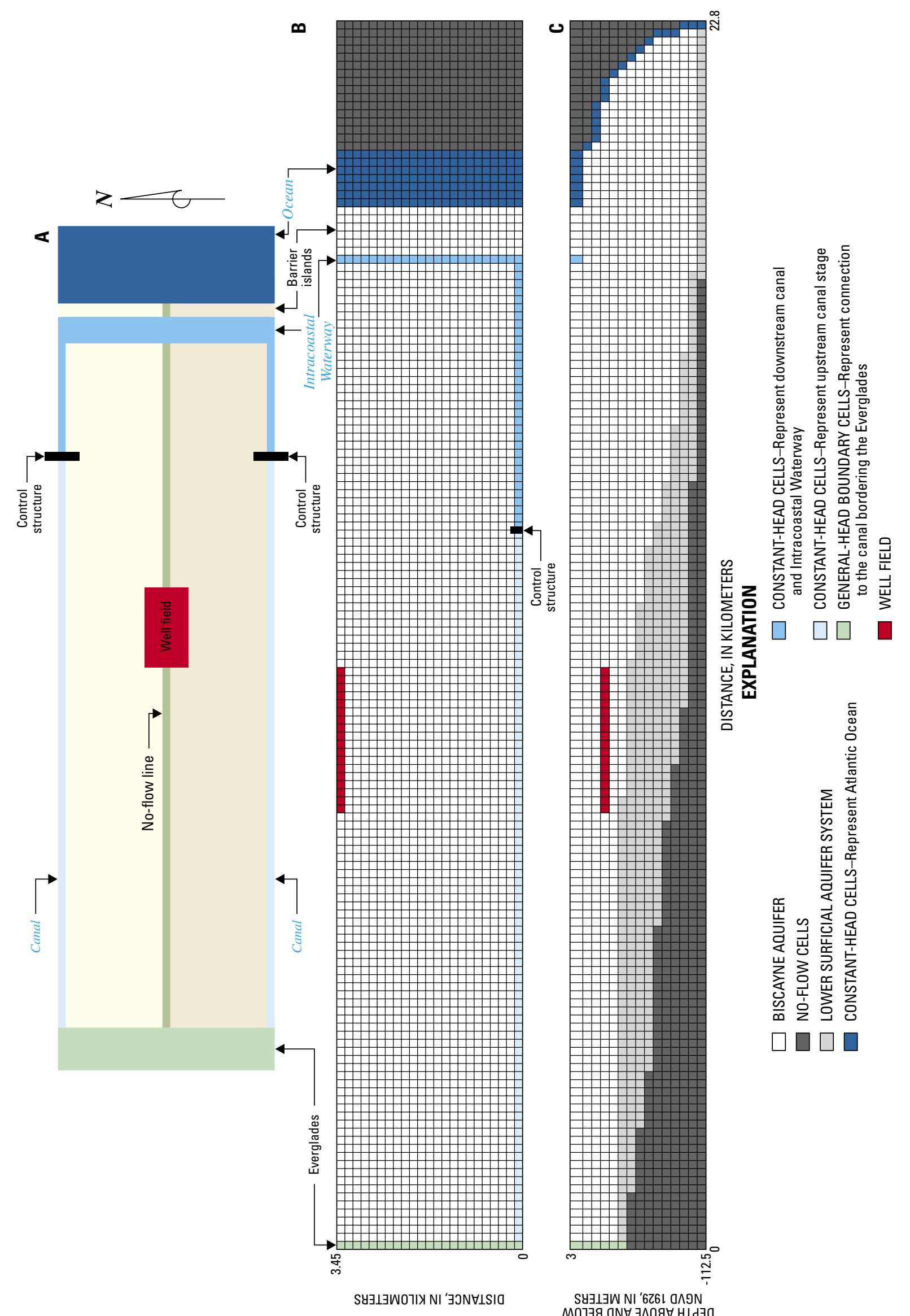

岸它号

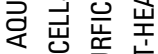

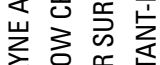

足

出 完高总

$\square \square \square \square$ 
parameters. Consequently, the estimated values for the aquifer parameters are more representative for all of Broward County than for one specific area. Simulated observation wells, henceforth referred to as simulated wells, are located in the model not by geographic location but instead by distance and direction from a control structure and by the depth of the open hole. For example, well G-2900 is about $1 \mathrm{~km}$ from the nearest canal, almost $2 \mathrm{~km}$ east of structure S-13, and is about $35 \mathrm{~m}$ deep. In the model, these distances and depth correspond with the cell at row 16, column 103, and layer 5. The model cells that correspond with the five other wells are determined in the same manner.

The constant-head cells used to represent the upstream and downstream parts of the canals were based on the stages and geometries of the canals within the area surrounding the Five Ash/Prospect Well Field (fig. 10). The constant-head cells representing the upstream canal and the GHB cells representing the connection to the Everglades were assigned a head value of $2.06 \mathrm{~m}$. This head value is equal to the average upstream stage for the 1990-99 period at structure S-37B on the Pompano Canal (fig. 10). The constant-head cells that represent the downstream part of the canal, Intracoastal Waterway, and Atlantic Ocean were assigned head values calculated from a sine function. The sine function was designed to provide stage fluctuations with an amplitude and frequency similar to the measured stage recorded at the downstream side of structure S-36 (fig. 24). (Ocean tidal data were not available for this area.) The constant-head cells that represent the downstream part of the canal extend about $4 \mathrm{~km}$ inland from the coast. This distance represents the average distance to the coast from structures S-36 and S-37A.

Average monthly values of precipitation (or rainfall) were assigned a monthly constant value of $14.02 \mathrm{~cm}$, which represents the average rainfall based on the average monthly rainfall during 1990-99 in the Five Ash/Prospect Well Field area (fig. 8A). Evapotranspiration is calculated by the model

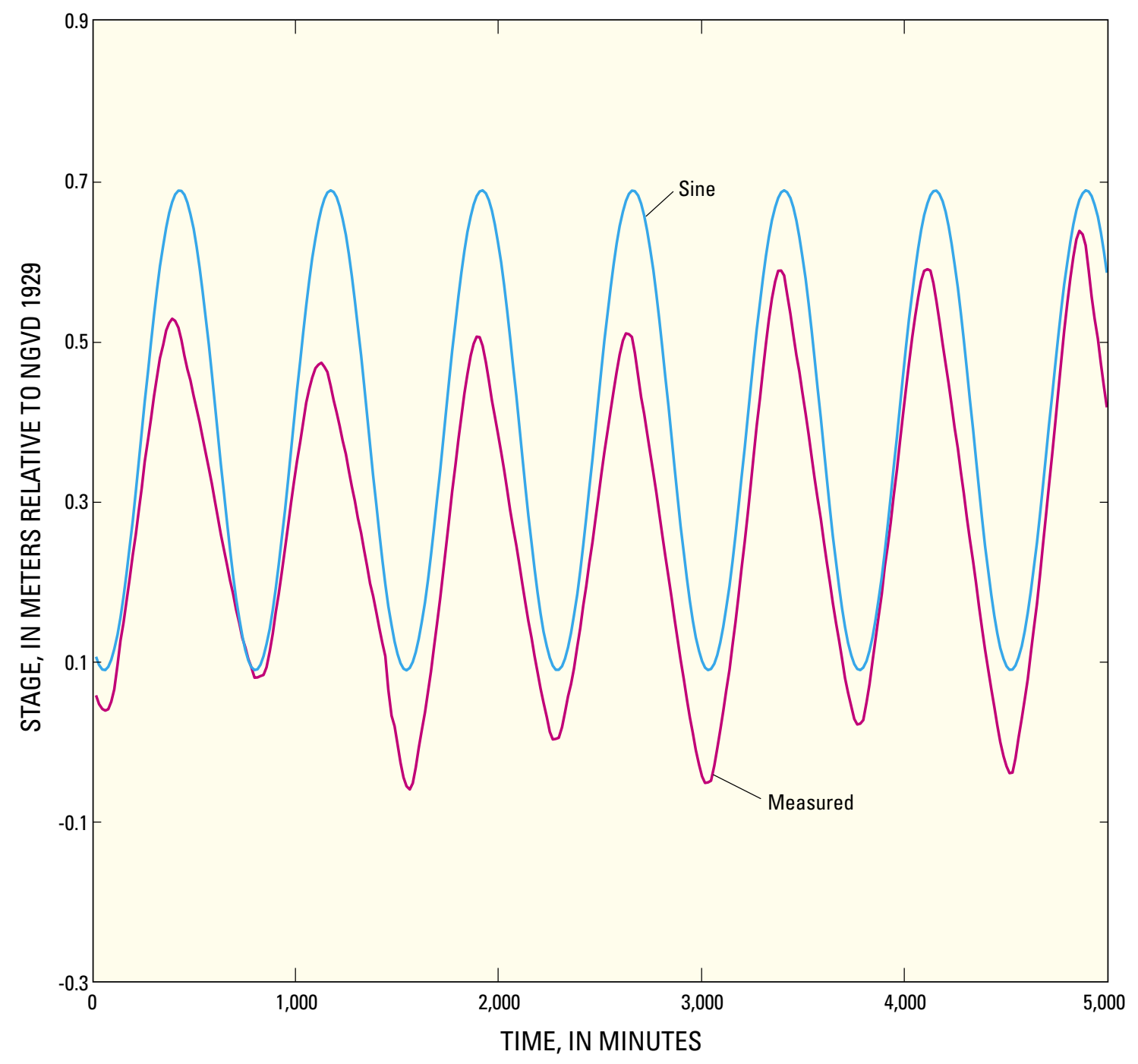

Figure 24. Stage measured at structure S-36 (downstream) compared to stage modeled using the sine function. 
based on the depth to the water table, an extinction depth of about $1.5 \mathrm{~m}$ (5 ft) (Langevin, 2001), and an average maximum evapotranspiration rate based on the values presented by Merritt (1996, p. 8). An average land surface value of $3.5 \mathrm{~m}$ was used to calculate depth to water for the entire model.

The model uses withdrawals from pumping wells at a constant rate of $79,406 \mathrm{~m}^{3} / \mathrm{d}$. This rate equals half the average daily rate at the Five Ash/Prospect Well Field during 1990-99 (fig. 8B), and was divided equally between 18 cells that withdraw water in the model.

Numerous 1-month simulations were done to estimate representative values for horizontal and vertical hydraulic conductivities, porosity, specific yield, and dispersivity. When the closest agreement was obtained between field and simulated data, the aquifer parameters were noted and used for the 10-year (1990-99) simulation. Horizontal and vertical hydraulic conductivities were set at 1,150 and $150 \mathrm{~m} / \mathrm{d}$, respectively, for the Biscayne aquifer and at 150 and $1.5 \mathrm{~m} / \mathrm{d}$, respectively, for the lower part of the surficial aquifer system. All hydraulic conductivity values were within ranges reported by Fish (1988) and Camp, Dresser, and McKee, Inc. (1980). Porosity and specific yield for the surficial aquifer system were each set at 0.1 , within the range of estimated porosity in the Biscayne aquifer at 0 to 0.5 (K.J. Cunningham, U.S. Geological Survey, oral commun., 2003). Model-derived longitudinal and transverse dispersivities were set at $2 \mathrm{~m}$ and $0.2 \mathrm{~m}$, respectively.

The approximate amplitude of measured water-level and salinity fluctuations in each well were compared to output from corresponding simulated wells in the 1-month model with constant amplitude fluctuations (table 2). The values from table 2 appear to be good matches between the simulated and measured data, considering that the model does not account for lithologic variations in the field because of model cell size and lack of lithologic data in the area. Other model runs with different parameters do not reveal as close a match as the final model run developed to simulate the effects of tides. For example, in well G-2900, tidal field and simulated water- level fluctuations differ by about $0.01 \mathrm{~m}$, whereas salinity (total dissolved-solid concentration) fluctuations in the model are smaller than those measured in the field. As previously mentioned, however, this difference likely results from the lack of lithologic variation in the model.

\section{Ten-Year Simulation}

A 10-year simulation model was developed to make predictions for movement of the saltwater interface over a longer time period than 1 month. The 10-year simulation consists of 120 monthly stress periods from 1990 to 1999. Stage input for the constant-head cells representing the canal, Intracoastal Waterway, and ocean cells is allowed to vary monthly during the simulation and is based on monthly averaged mean daily value data for structure S-36 (downstream) (fig. 25) stored in the USGS National Water Inventory System (NWIS) data base. The initial salinity concentrations assigned to each constant-head cell are specified recharge from the canal and do not change with each stress period; however, they are not constant-concentration cells and will vary with concentration fluxes into and out of each cell.

The constant-head cells representing the upstream canal and the GHB cells representing the connection to the Everglades were assigned stage values from control structure S-37B (upstream stage). These daily values from the DBHYDRO data base of the SFWMD were averaged monthly from 1990 to 1999. The stage values above structure S-37B are the highest in the area and recharge much of the Five Ash/Prospect Well Field area represented in the model. The downstream stage values from S-37B, however, are not used to represent the ocean stage values because there is a structure (S-37A) between S-37B and the ocean. Therefore, the downstream stage from structure S-36, a similar distance from the ocean as structure S-37B, is used to reflect stage values associated with the ocean.

Table 2. Measured and simulated salinity and water-level data from selected continuous monitoring wells in Broward County.

\begin{tabular}{|lcccc} 
Well & $\begin{array}{c}\text { Salinity amplitude based on } \\
\text { dissolved-solids concentration } \\
\text { (grams per liter) }\end{array}$ & \multicolumn{2}{c}{$\begin{array}{c}\text { Water-level } \\
\text { amplitude } \\
\text { (meters) }\end{array}$} \\
\hline & $\begin{array}{c}\text { Measured } \\
\text { field data } \\
\text { (estimated) }\end{array}$ & $\begin{array}{c}\text { Simulated } \\
\text { representation }\end{array}$ & $\begin{array}{c}\text { Measured } \\
\text { field data } \\
\text { (estimated) }\end{array}$ & $\begin{array}{c}\text { Simulated } \\
\text { representation }\end{array}$ \\
\hline G-2270 & 0.002 & 0.00068 & 0.02 & 0.011 \\
\hline G-2784 & None (fresh) & None (fresh) & .03 & .05 \\
\hline G-2785 & .001 & .001 & .03 & .05 \\
\hline G-2897 & .04 & .006 & .02 & .043 \\
\hline G-2898 & .03 & .058 & .08 & .32 \\
\hline G-2900 & .03 & .007 & .04 & .031 \\
\hline
\end{tabular}




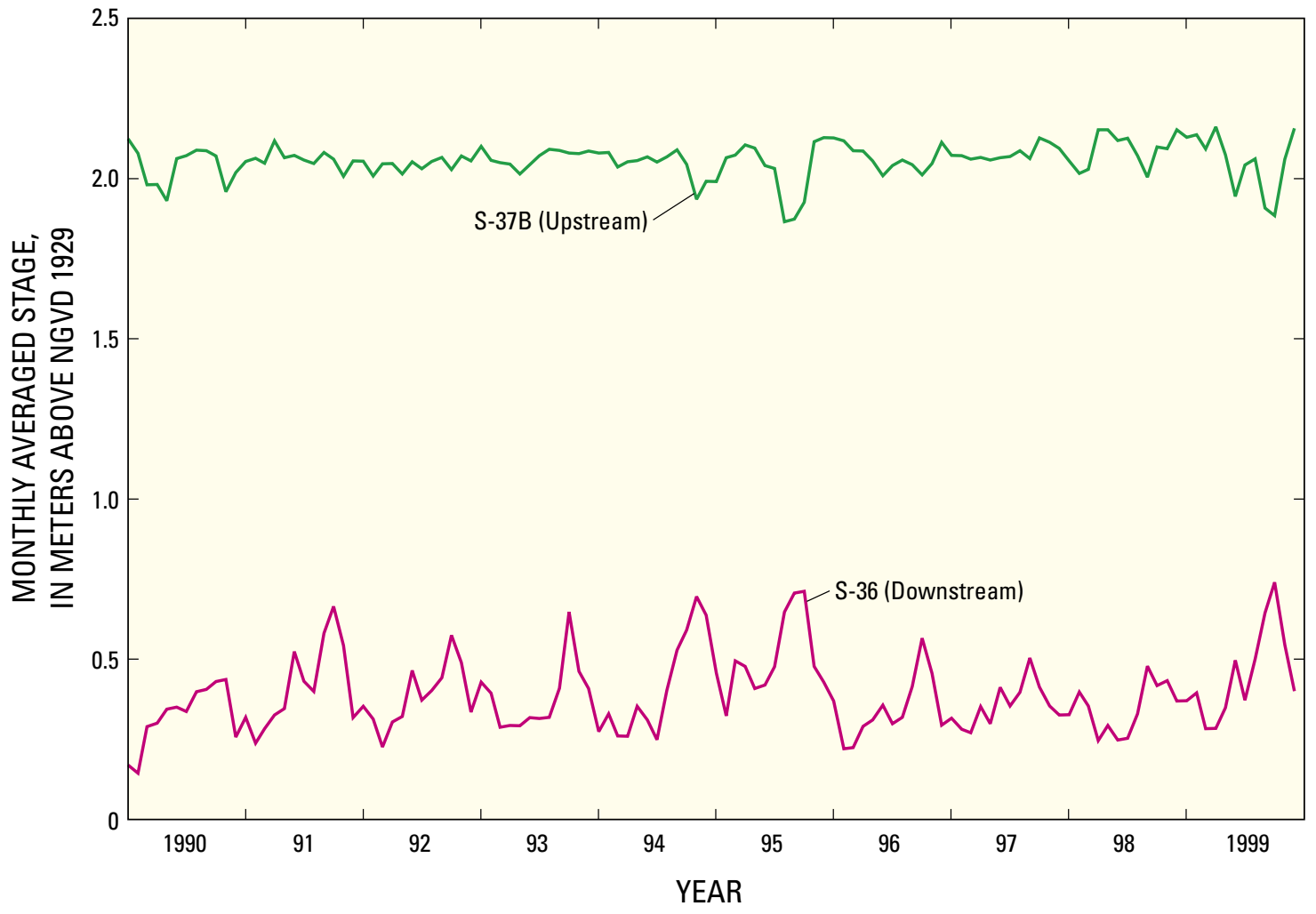

Figure 25. Upstream and downstream canal stage input for the 10-year (1990-99) simulation.

The well-field pumpage used for the simulation is half of the actual withdrawal from the Five Ash/Prospect Well Field during 1990-99 (fig. 8B). One-half of the well-field pumpage each month was input into the model, with the assumption that a municipal well field is located halfway between two east-west canals (as previously mentioned). Therefore, the contributing area is cut in half, which justifies cutting the pumpage in half.

Simulated recharge also is allowed to vary monthly over the 10-year period. Rainfall data from stations in the Five Ash/Prospect Well Field area are averaged each month during the period of simulation (fig. 8A). Direct runoff into the canals is not simulated in the model; however, applying recharge to the system assumes shallow ground-water flow to the canal instead of direct runoff into the canal. Additionally, Broward County contains many French drains that are designed to recharge the Biscayne aquifer and collect runoff from rainfall.

Maximum evapotranspiration rates from Merritt (1996, p. 8) were used each month and repeated annually. The use of constant rates is based on the assumption that for each year during 1990-99, about the same amount of evapotranspiration would occur if ground-water levels were consistent from year to year. With the constant fixed extinction depth but varying ground-water levels over time, the simulated evapotranspiration rates change from year to year during the 10-year simulation.
For the 10-year simulation, longitudinal dispersivity was set at $3 \mathrm{~m}$, and the transverse and vertical dispersivities were each set at $0.3 \mathrm{~m}$. The difference in dispersivity between the 10-year model and 1-month tidal model $(2 \mathrm{~m}$ and $0.2 \mathrm{~m}$, respectively) was necessary because of the difference in temporal variation between the two models. Dispersion increases with an increase in temporal variations in water level, such as tides. Tides were averaged monthly in the 10year simulation; therefore, dispersivity values were increased to compensate for the dampened tidal variation.

\section{Ground-Water Flow Patterns and Water Budget}

In the 10-year model, most ground water discharges into the ocean, Intracoastal Waterway, well field, and downstream canal (fig. 26A-B). During the wet period, (fig. 26A), a slight westward gradient indicates flow to the Everglades. Additionally, the mound of water in the western part of the model (created by recharge) discharges water to the upstream canal. During the dry period (fig. 26B), the predominant groundwater-flow direction is from west to east, with the highest water levels in the model occurring at the upstream canal. During both wet and dry periods, head contours are lower near 

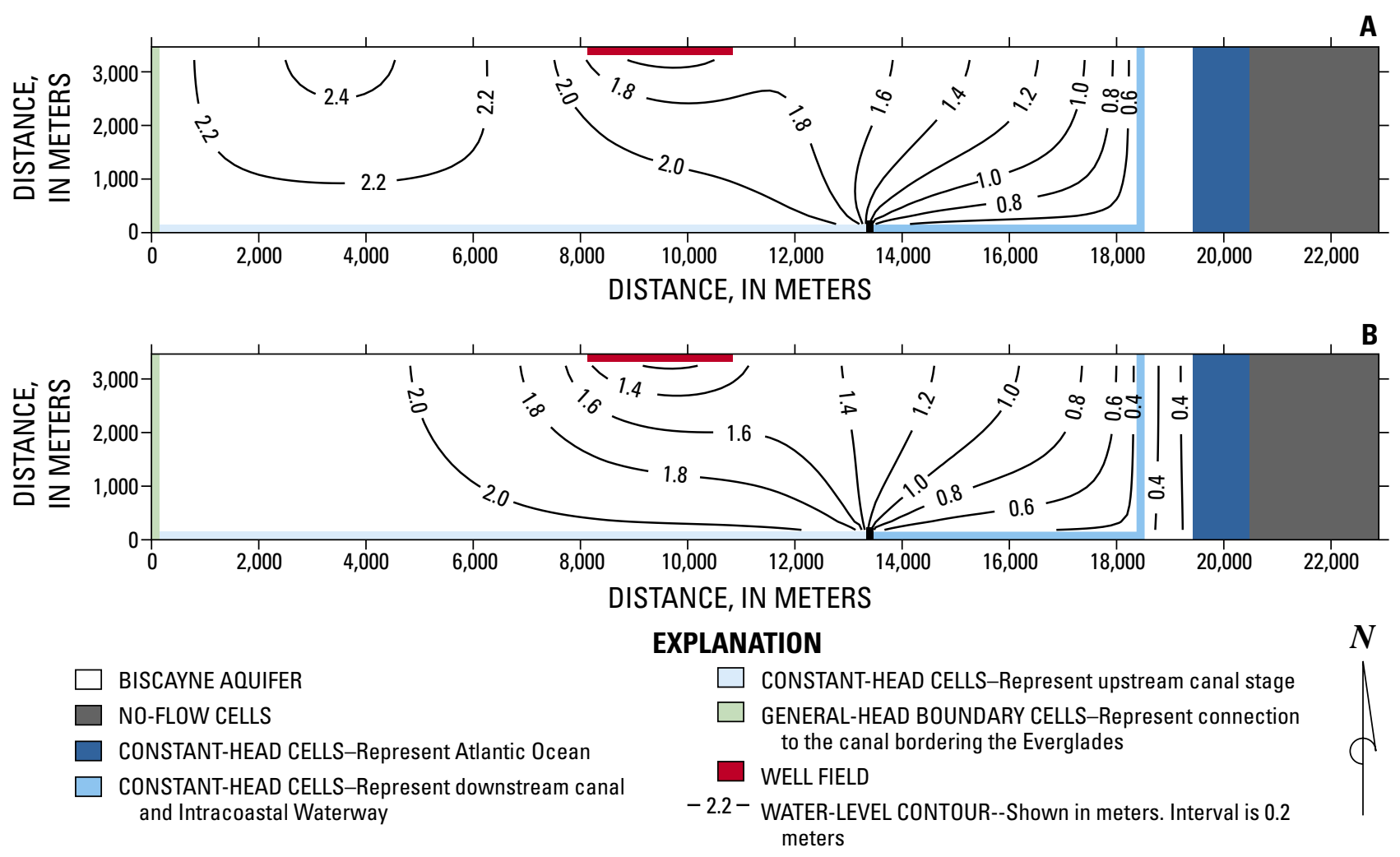

Figure 26. Map view of water-level contours from model results during a (A) wet period (stress period 8) in August and (B) dry period (stress period 12) in December.

the well field because of ground-water withdrawals. Head contours indicate that ground water flows toward the canal and around the control structure. The high gradient around the control structure indicates that the structure and canal have a major effect on the ground-water flow system. The gradient in the model is comparable to the effect that control structures and canals have on water levels throughout Broward County as shown by the altitude of the water table (fig. 2).

A water budget was prepared from the model results to demonstrate the relative importance of different hydrologic boundaries (fig. 27), and it represents an average for the entire 10-year period. The simulated upstream canal contributes a large amount of water into the system, second only to recharge. The upstream canal and rainfall are the main freshwater sources for the aquifer, and the ocean is the only boundary that contributes saltwater to the system. Although evapotranspiration, the Intracoastal Waterway, and well-field withdrawals remove much of the water from the system, the downstream canal constitutes a large part (about 50 percent) of the discharge from the aquifer. The water budget and waterlevel contours (fig. 26A-B) indicate that canals substantially affect overall ground-water flow patterns in Broward County. Based on the model results, a canal may add or remove water from the system depending on the surface- and ground-water stage and proximity to a control structure.

\section{Comparison of Model Results with Field Data}

Although the numerical model is more representative of average conditions in Broward County than of one particular area, results from the model were compared with field data to ensure that the 10-year simulation adequately represents the system. The hydrologic boundaries in the 10-year simulation use 1990-99 data, primarily from the Five Ash/Prospect Well Field area, as input. In the field, the southern half of this area is hydrologically and lithologically similar, but not identical, to the northern half. Therefore, the modeling approach, which assumes that the northern and southern parts are hydrologically identical (fig. 23A), precludes the ability to calibrate the model with certainty using field data from the area surrounding the Five Ash/Prospect Well Field. Because of the similarities between the model and the well-field area, simulated water levels were compared with field data collected in this area during 1990-99.

Water-level data were collected from monitoring wells G-820A, G-2033, G-2443, and G-2444 in the Five Ash/Prospect Well Field area during 1990-99 (fig. 28). A GIS coverage was used to measure the distance of each well from the nearest canal and the distance between the well and the nearest control structure. The monitoring wells were then simulated in the model grid based on well depth and well distance from canals and control structures. The time-series plots shown in 


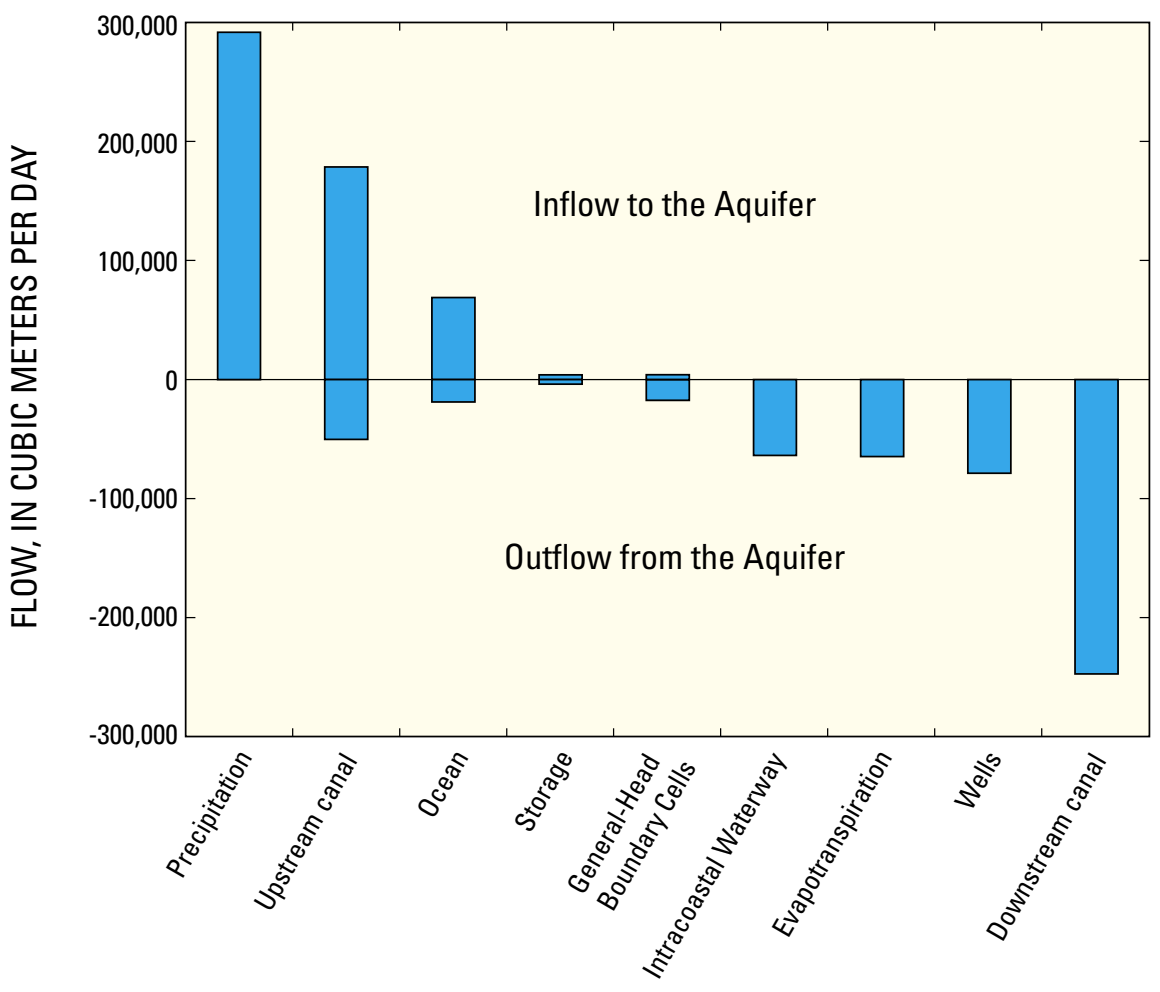

WATER-BUDGET COMPONENTS
Figure 27. Water budget for the 10 -year (1990-99) simulation. The flow ranges are of monthly averages for the entire 10-year simulation.

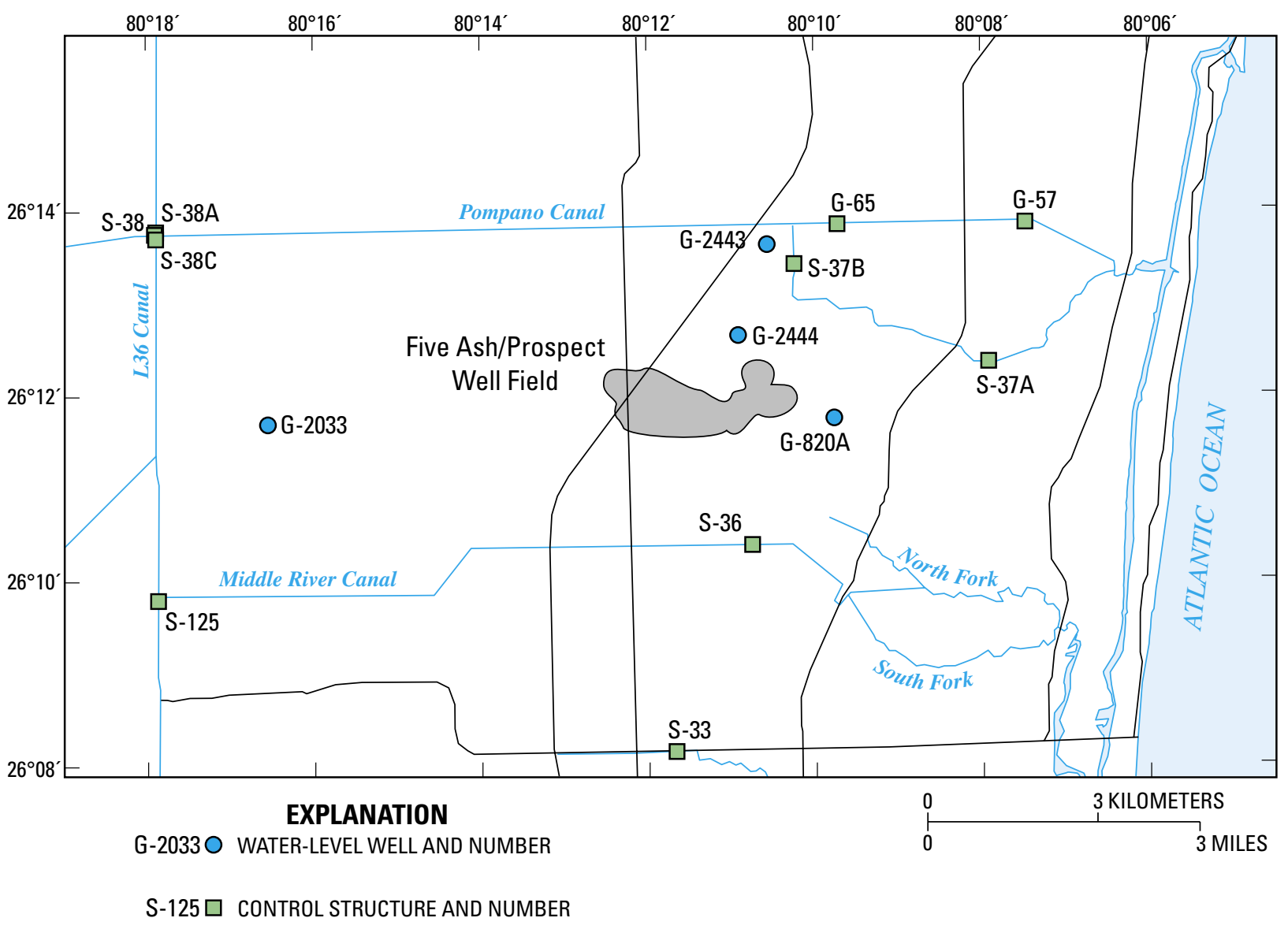

Figure 28. Location of selected wells used for water-level data collection in the Five Ash/Prospect Well Field area. 
figure 29 compare the simulated water levels from the model results with the measured water levels from the field. Even though wells G-820A, G-2443, and G-2444 have measured water levels for only the first 5 years, the match between measured and simulated water levels is very close for wells G-820A and G-2443. Simulated water levels are somewhat higher than measured water levels for well G-2444; however, the match is relatively good considering that measured field data are being matched to output from a representative model.

A
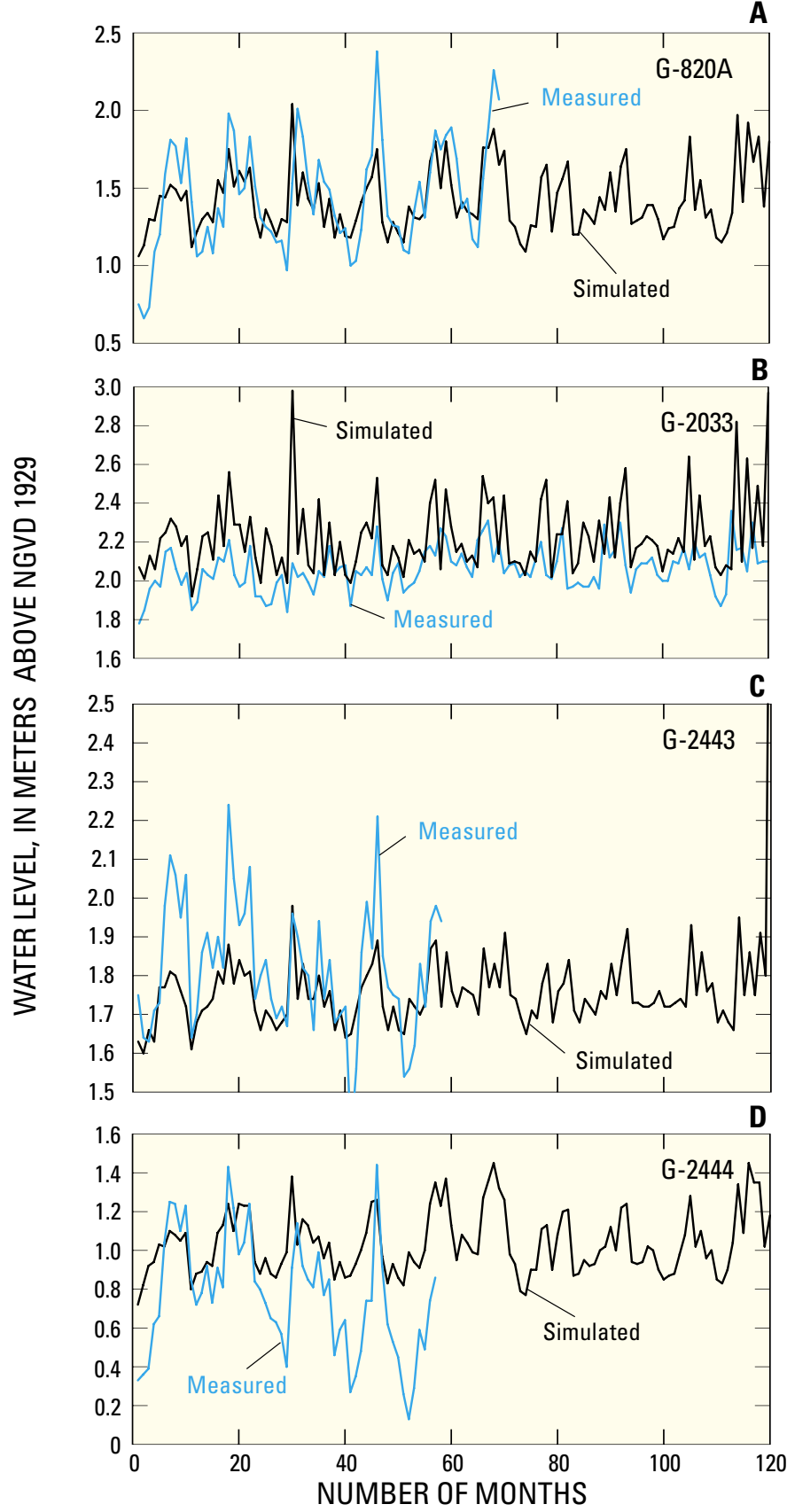

Figure 29. Comparison of measured and simulated water-level data from wells G-820A, G-2033, G-2443, and G-2444 in the Five Ash/Prospect Well Field area during 1990-99.
For well G-2033, the simulated water levels are slightly higher than the measured water levels, but the match is still close. Water-level results from these four simulated wells indicated that the model reasonably simulates water levels in the field.

The model calculates net flow from the constant heads (representing the upstream canal) to the aquifer as 128,163 $\mathrm{m}^{3} / \mathrm{d}$. A dye tracer test was conducted in the Five Ash/ Prospect Well Field area, and test results indicated that the Pompano Canal above structure 37B (fig. 2) recharges the well-field area at a rate of about $113,546 \mathrm{~m}^{3} / \mathrm{d}$ or greater (Dave Markward and Fran Henderson, Broward County Office of Environmental Services, written commun., 2002). Considering that the 10-year model is only representative and uses data from the Five Ash/Prospect Well Field area, the numbers representing the flow into the system are comparable.

In this report, the toe of the saltwater interface is considered to be the inland extent of the $250-\mathrm{mg} / \mathrm{L}$ chloride concentration line at the base of the aquifer and/or rock formation. The model was used to evaluate saltwater intrusion at the base of the Biscayne aquifer and the lower part of the surficial aquifer system. A comparison of the simulated and measured saltwater toe location at the base of the Biscayne aquifer revealed that the model simulates the location of the saltwater interface relatively well (fig. 30). The simulated toe location in the lower part of the surficial aquifer system also is shown in figure 30. No data were available from the Five Ash/Prospect Well Field to infer the actual toe location at the base of the surficial aquifer system for comparison with the simulated toe location. The comparison of simulated and actual toe location at the base of the Biscayne aquifer, in conjunction with the net flow comparisons and time-series plots (fig. 29) indicates that the model can reasonably simulate hydrologic conditions for the Biscayne aquifer in Broward County.

\section{Evaluation of Saltwater Intrusion}

Salinity concentration graphs were generated from selected cells in the model to evaluate the potential movement of the saltwater interface. Model cells near the canal (E, F, and G) show a much larger response to hydrologic stresses than model cells located farther from the canal such as A, B, and D (fig. 31A-C). The large salinity concentration changes in cells beneath the canal indicate movement of the saltwater interface. These changes are caused primarily by the change in head difference between the upstream and downstream canal stages (fig. 32). Model cells near the well field (fig. 31A-C, cells $\mathrm{A}$ and $\mathrm{B}$ ) show no salinity concentration fluctuations resulting from well-field withdrawal, recharge, or canal stage changes.

Although the observation cells are placed in both the Biscayne aquifer and lower part of the surficial aquifer system, the distance of the cells from the top of the model does not seem to affect the amplitude of salinity concentration fluctuations. For example, cell $\mathrm{G}$ in the lower part of the surficial aquifer system beneath the canal and cell $\mathrm{F}$ in the Biscayne aquifer both have similar salinity concentration fluctuations that are larger than those of the other wells. 


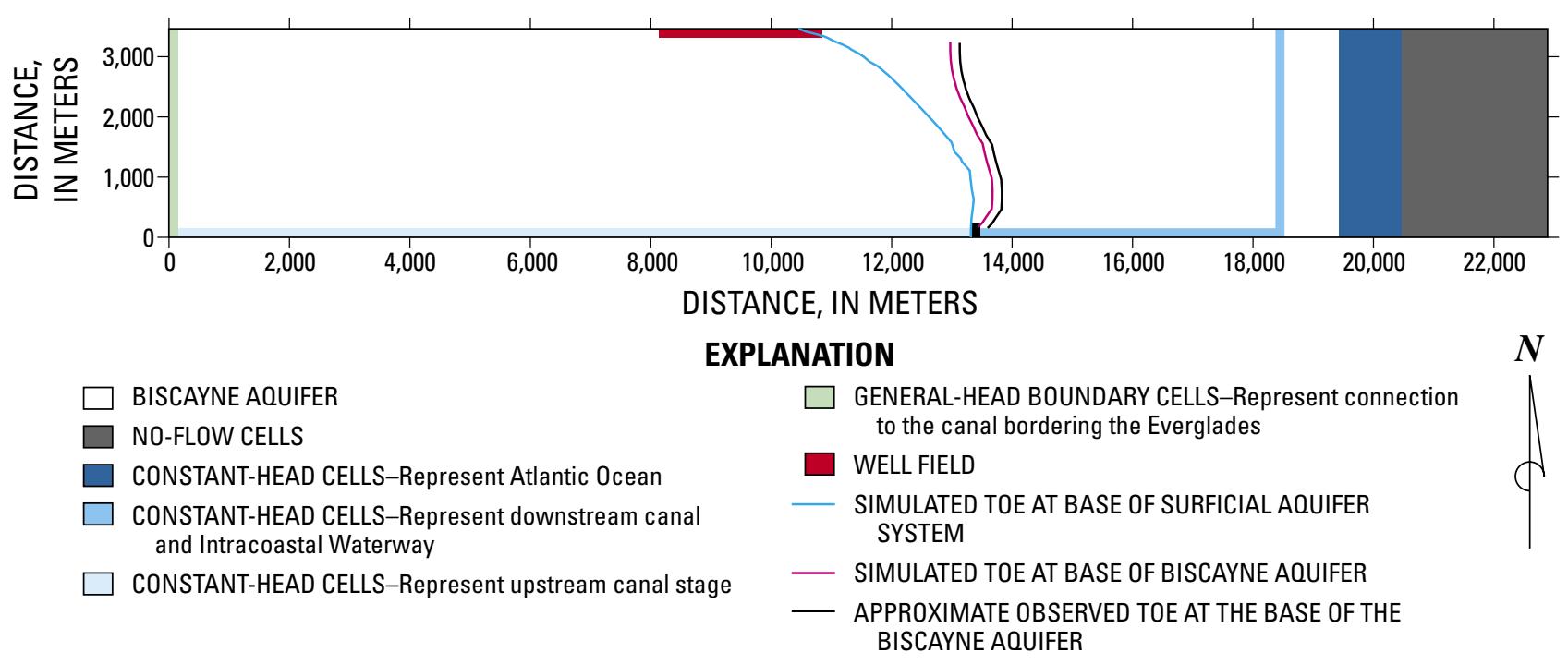

Figure 30. Comparison of the measured and simulated saltwater toe locations at the base of the Biscayne aquifer and the simulated toe location at the base of the surficial aquifer system at the end of the 10-year simulation.

\section{Upconing}

Upconing is defined as the upward movement of the saltwater interface beneath a well field in response to lowered heads caused by well-field withdrawals. Upconing is one process (as opposed to lateral movement of the saltwater interface) that can affect municipal well fields by causing increased chloride concentrations in the production zone.

At the end of the 10-year (1990-99) simulation, the position of the saltwater interface toe in the surficial aquifer system (fig. 30) indicates that upconing may be occurring beneath the well field (fig. 33). An upward deflection of the $250-\mathrm{mg} / \mathrm{L}$ chloride concentration contour occurs within the surficial aquifer system beneath the well field. During the 10-year simulation period, however, chloride concentrations in the pumping wells never exceeded the potable limit (250 mg/L). Simulation results (figs. 30 and 33) indicated that the saltwater interface would probably move much closer to pumping wells in the lower part of the surficial aquifer system than in the Biscayne aquifer. Monitoring wells tapping only the Biscayne aquifer would not reflect the saltwater intrusion from the lower part of the surficial aquifer system.

\section{One-Foot Rule}

To prevent saltwater intrusion, the SFMWD established the $1-\mathrm{ft}(0.3048-\mathrm{m})$ rule, which is used in the permitting process for coastal well fields. This rule is based on the assumption that saltwater intrusion will not occur if the highest point of ground-water head between the well field and the saltwater interface is at least $1 \mathrm{ft}(0.3048 \mathrm{~m})$ higher than the ground-water head at any location along the front of the saltwater interface-defined as the location of the $250-\mathrm{mg} / \mathrm{L}(0.46$ total dissolved solids) chloride concentration contour (South
Florida Water Management District, 2002). Results from the 10 -year simulation were used to evaluate the effectiveness of the $1-\mathrm{ft}(0.3048-\mathrm{m})$ rule as a method for preventing saltwater intrusion.

To evaluate the $1-\mathrm{ft}(0.3048-\mathrm{m})$ rule, the different model results were plotted for two simulated observation wells ( $\mathrm{X}$ and $\mathrm{Y}$ ) between the well field and the saltwater interface in the Biscayne aquifer (fig. 33). The simulated observation well $(\mathrm{X})$ near the well field corresponds with the location of the highest head between the well field and the saltwater interface. The other simulated observation well (Y) is located at the position of the saltwater interface. Both simulated wells are located at the depths of the production zone for pumping wells. The difference in head between these two simulated wells and the simulated salinity concentration at the saltwater interface well is plotted as a function of time (fig. 34). During certain times of the simulation period, the $1-\mathrm{ft}(0.3048-\mathrm{m})$ rule is met when the head difference exceeds this value; however, the $1-\mathrm{ft}(0.3048-\mathrm{m})$ rule is not met for more than half of the 10-year simulation period. Despite this difference, there does not seem to be a substantial inward movement of saltwater.

To further evaluate the $1-\mathrm{ft}(0.3048-\mathrm{m})$ rule using model results, the monthly change in salinity concentration at simulated observation well Y on the saltwater interface was calculated by subtracting the concentration at the beginning of the month from the concentration at the end of the month. Thus, a positive value indicates that the salinity concentration increased during the month, which implies inland movement of the saltwater interface. A negative value indicates that the salinity concentration decreased during the month, which implies seaward movement of the saltwater interface. These salinity concentration changes are plotted relative to the simulated head difference between simulated observation wells 

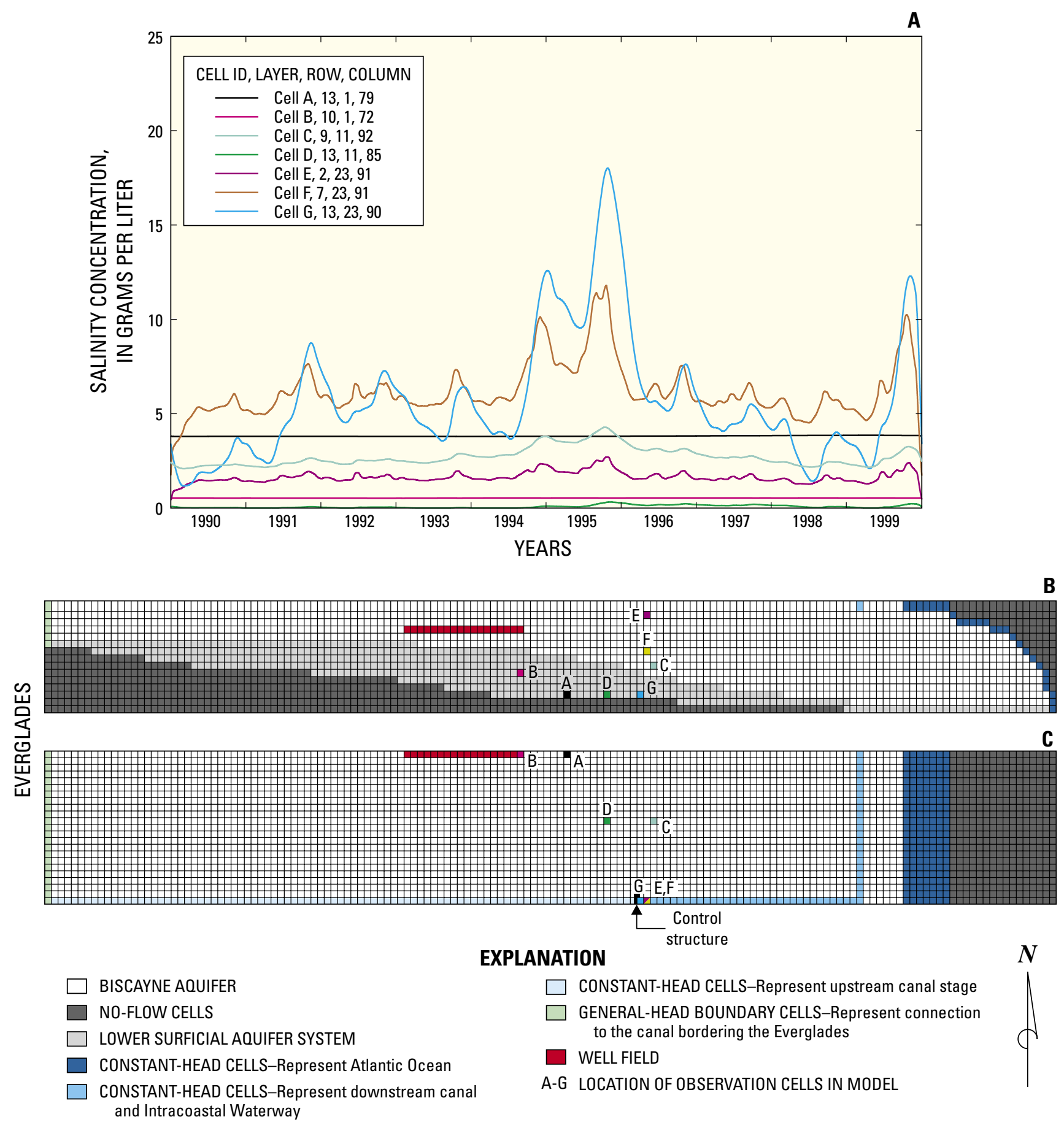

Figure 31. (A) Relation between salinity concentration and time at selected cells in the 10 -year model, (B) cross-sectional view of the model depicting the depth of each observation cell, and (C) map view of the model depicting the areal location of each observation cell. The color used for each observation cell is identical in the graph and grids. 


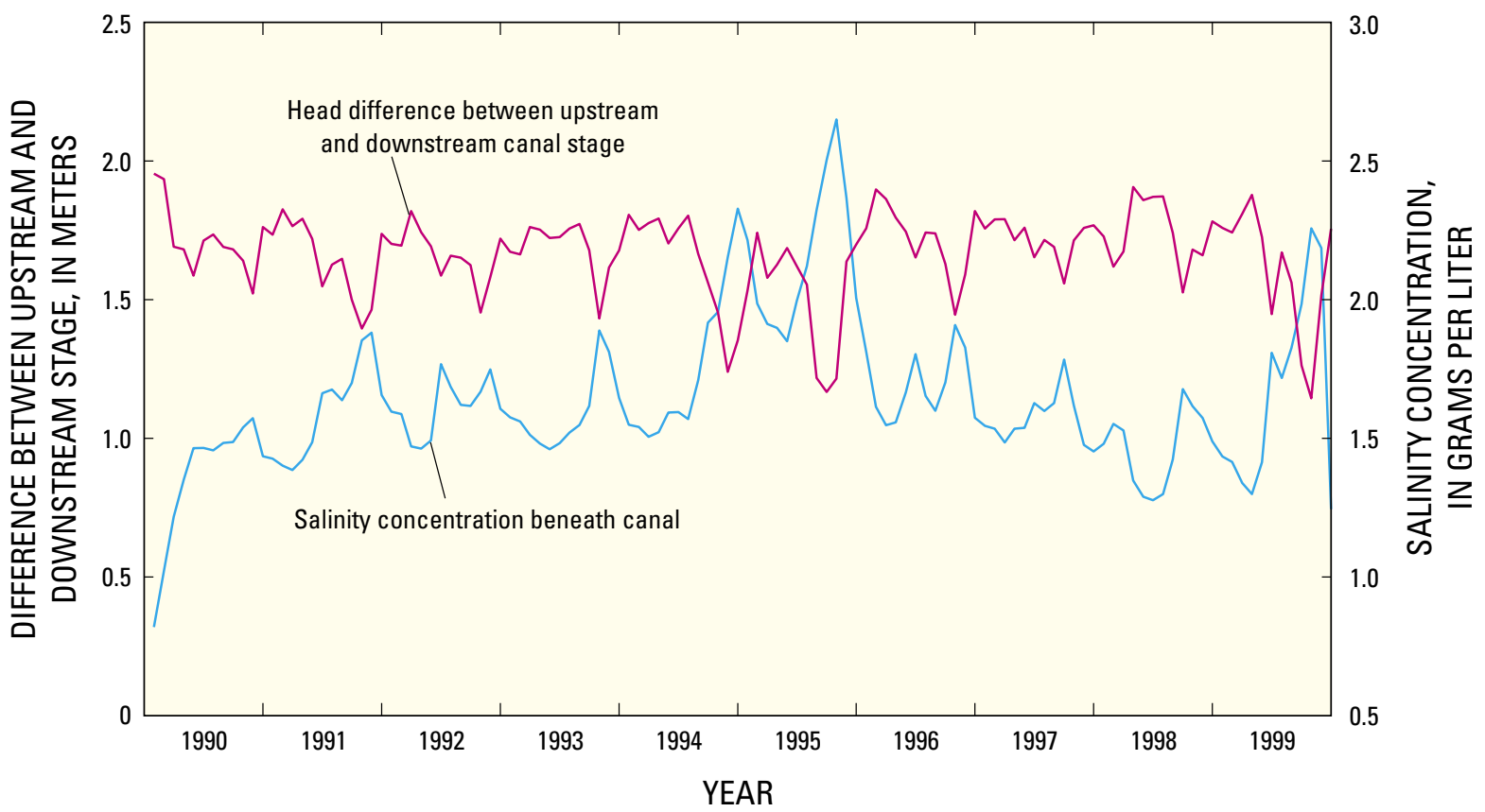

Figure 32. Head difference between upstream and downstream canal stage in the model and total dissolved-solids concentration beneath the canal.

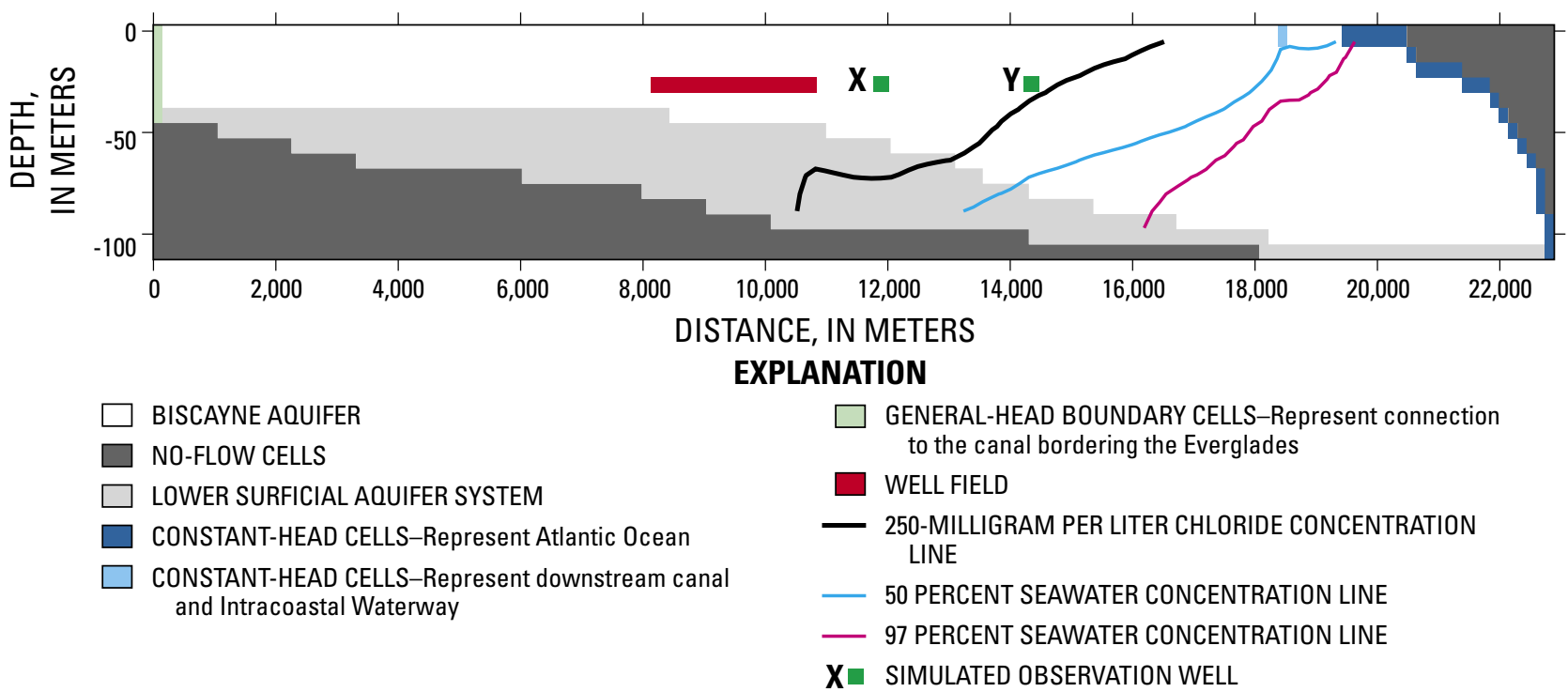

Figure 33. Cross-sectional view of model grid depicting upconing beneath the well field for the end of the 10-year simulation. Well $\mathrm{X}$ measures the highest head point between the well field and the observation well $(\mathrm{Y})$ at the saltwater intrusion front. 


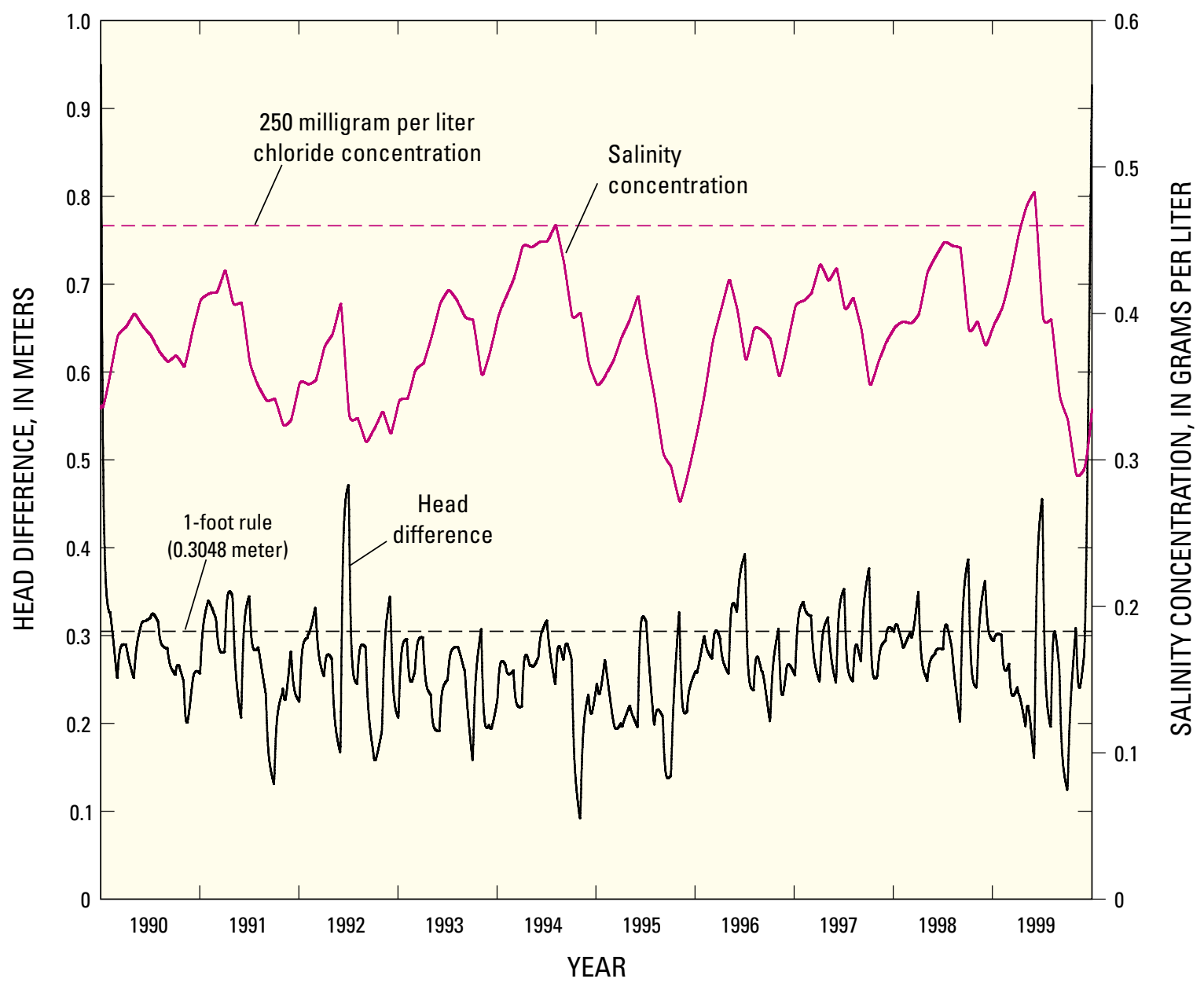

Figure 34. Head difference between two observation wells ( $X$ and $Y$ ) used to establish the 1-foot (0.3048-meter) rule compared to the total dissolved-solids concentration at the saltwater interface measured at observation well $Y$.

$\mathrm{X}$ and $\mathrm{Y}$ for that month in figure 35 . As would be expected, when the head difference between the two simulated observation wells increases and the saltwater interface moves seaward, salinity concentrations decrease. There is no strong correlation, however, with change in salinity concentration at the saltwater interface and the head difference between the two simulated observation wells (the $\mathrm{R}^{2}$ value for a linear regression is 0.0192).

The 1-ft $(0.3048-\mathrm{m})$ rule was established to prevent well-field induced saltwater intrusion. Based on the hydrologic conditions tested by the model, however, no strong correlation seems to exist between movement of the saltwater interface and the head difference between the interface and inland areas. Therefore, the $1-\mathrm{ft}(0.3048-\mathrm{m})$ rule does not appear to be a valid criterion for preventing saltwater intrusion. Other statistical analyses were performed to determine if another parameter might be better related to saltwater interface movement than the head difference at two simulated observation wells. Rainfall, well-field withdrawals, and changes in canal stage were all evaluated by linear regression techniques to determine the effects on saltwater intrusion. Results from the regression analyses indicated that salinity changes are related to different parameters for areas near the well field than for areas near the canal within the system. Near the well field and away from the canal, salinity changes (and thus saltwater interface movement) seem to be highly related to rainfall. Monthly averaged total dissolved-solids concentration changes (at the saltwater interface near the well field) are more closely related to the monthly rainfall total (fig. 36) than to the head difference between two simulated wells. If monthly rainfall is less than about $14 \mathrm{~cm}$, salinity concentrations increase, suggesting that the saltwater interface moves inland. If monthly rainfall is about $14 \mathrm{~cm}$ or greater, salinity concentrations decrease, suggesting that the saltwater interface moves seaward. Near the canal, however, saltwater interface movement is better related to the difference between the upstream and downstream canal stage (fig. 37). The saltwater interface moves downward (fig. 32) and seaward as the difference between upstream and downstream canal stage increases.

The head difference between the two simulated observation wells (fig. 34) is affected by rainfall, pumpage, and canal stage change - the head difference between the upstream and downstream canal stage. Figure 38 shows the relation between 


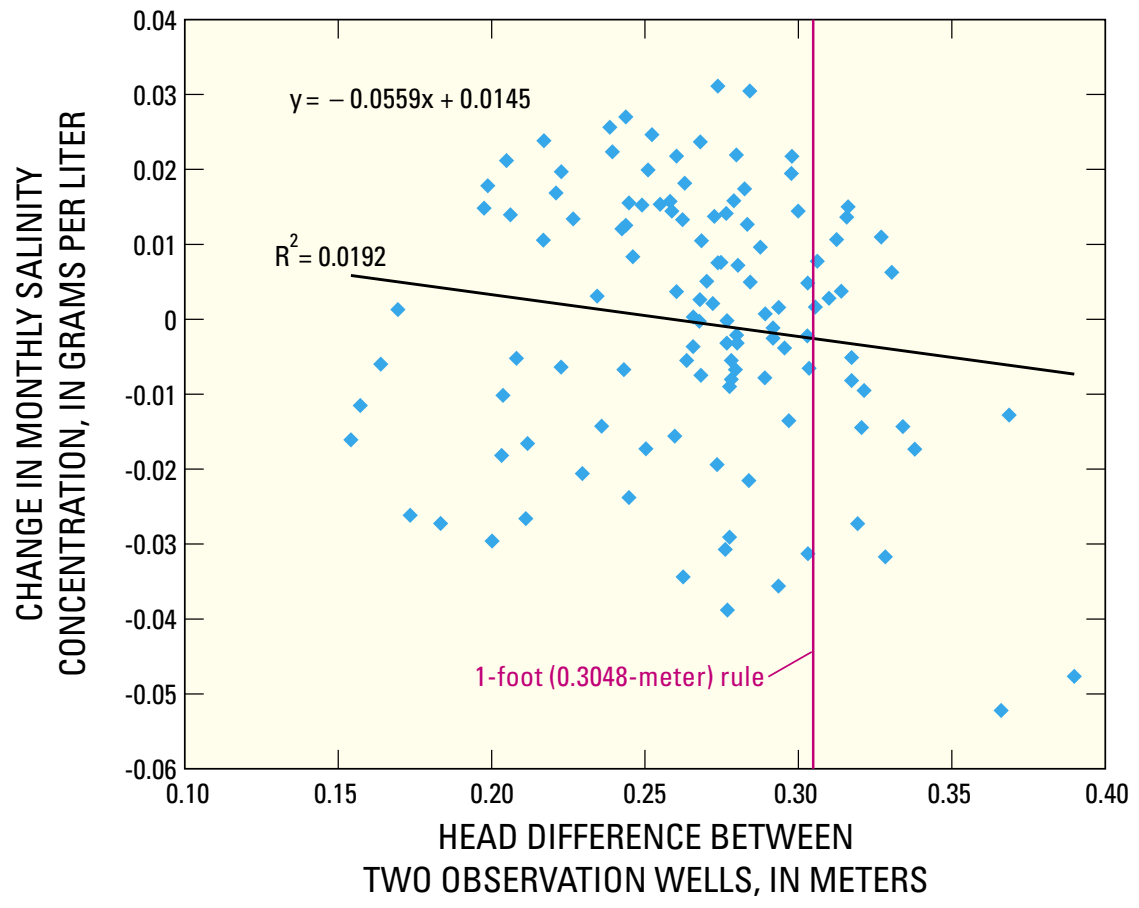

Figure 35. Linear regression of the head difference between two observation wells and the change in total dissolved-solids concentration of the observation well at the saltwater interface. $R^{2}$ is the coefficient of determination.

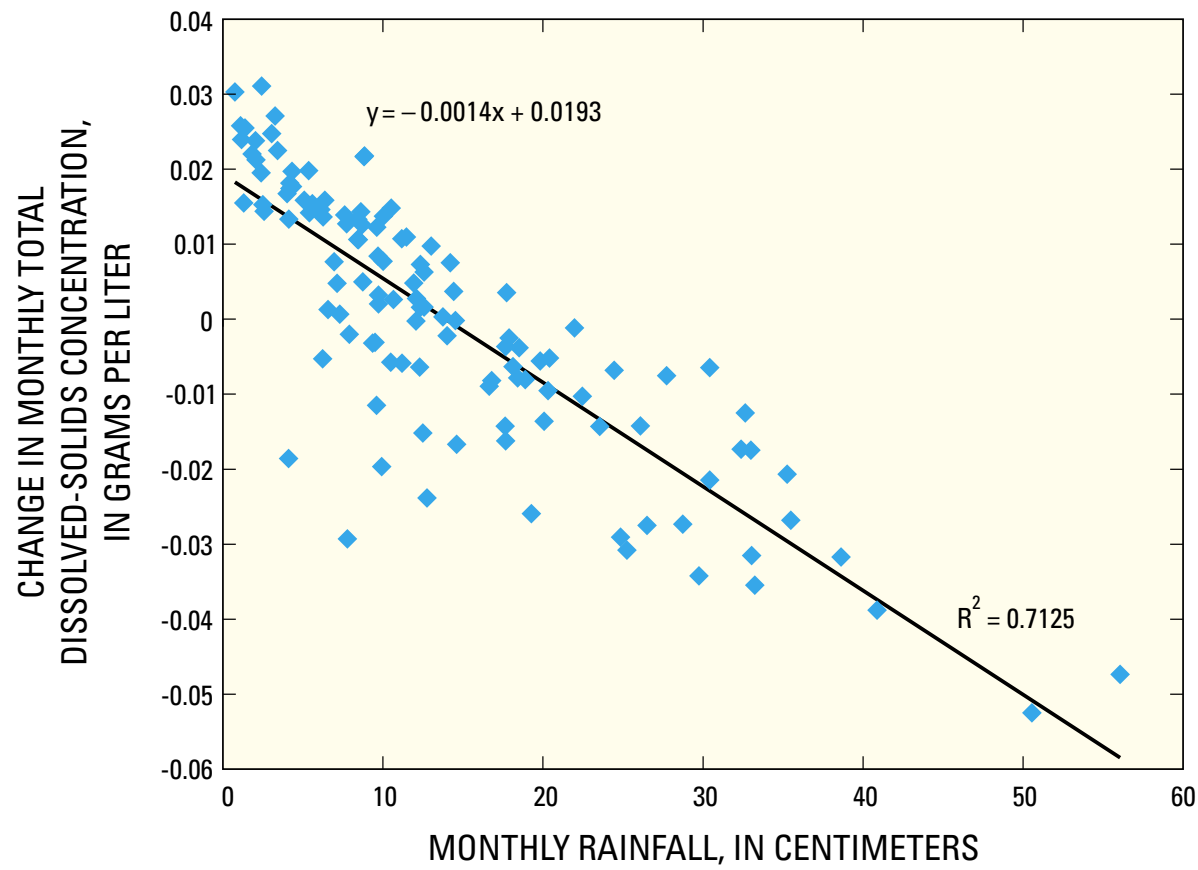

Figure 36. Linear regression of the rainfall in the model and the change in total dissolvedsolids concentration (from one month to the next) of observation well $\mathrm{Y}$ at the saltwater interface. $R^{2}$ is the coefficient of determination. 


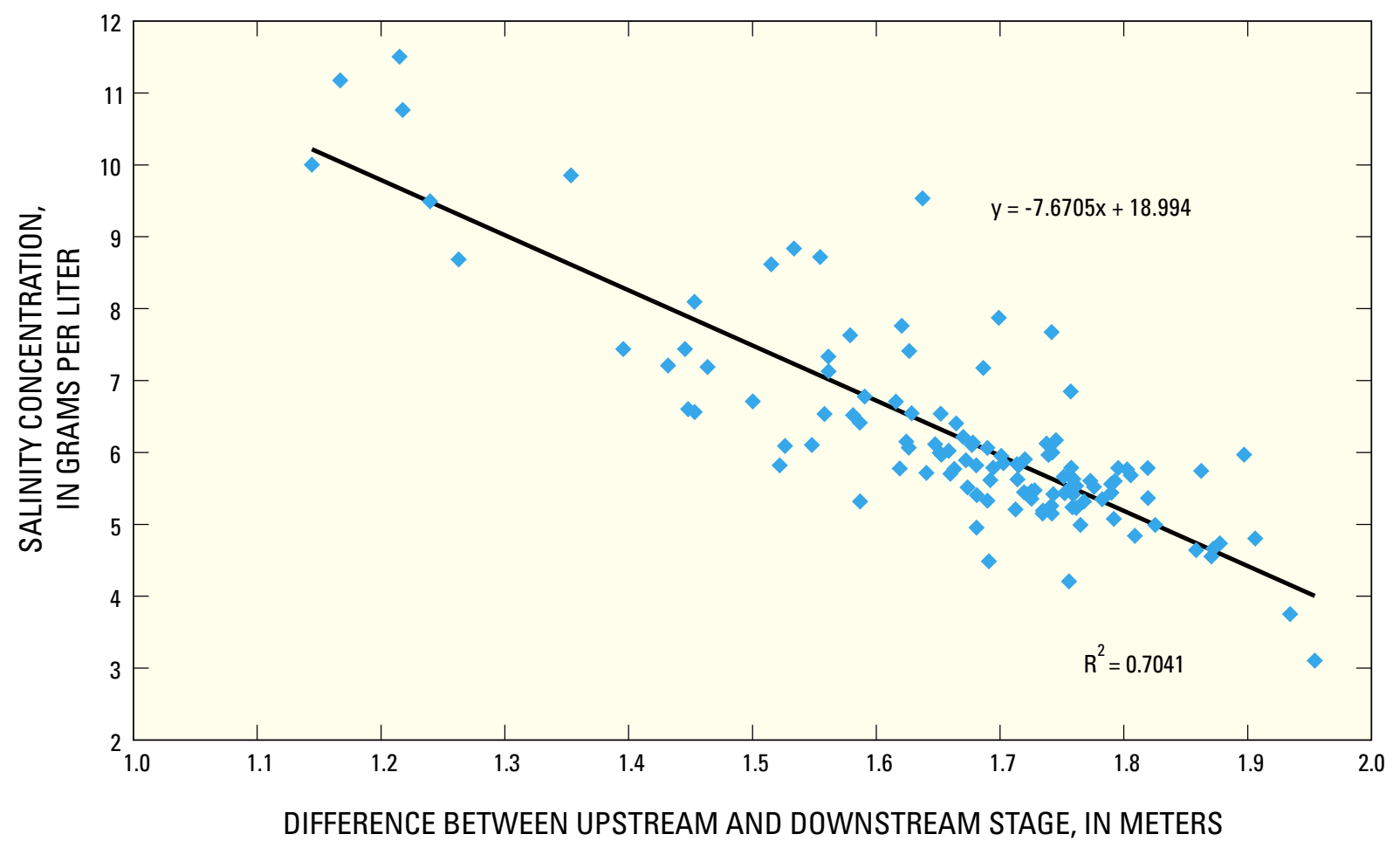

Figure 37. Linear regression of the difference between the upstream and downstream canal stage and total dissolved-solids concentration at an observation well beneath the downstream canal. $R^{2}$ is the coefficient of determination.

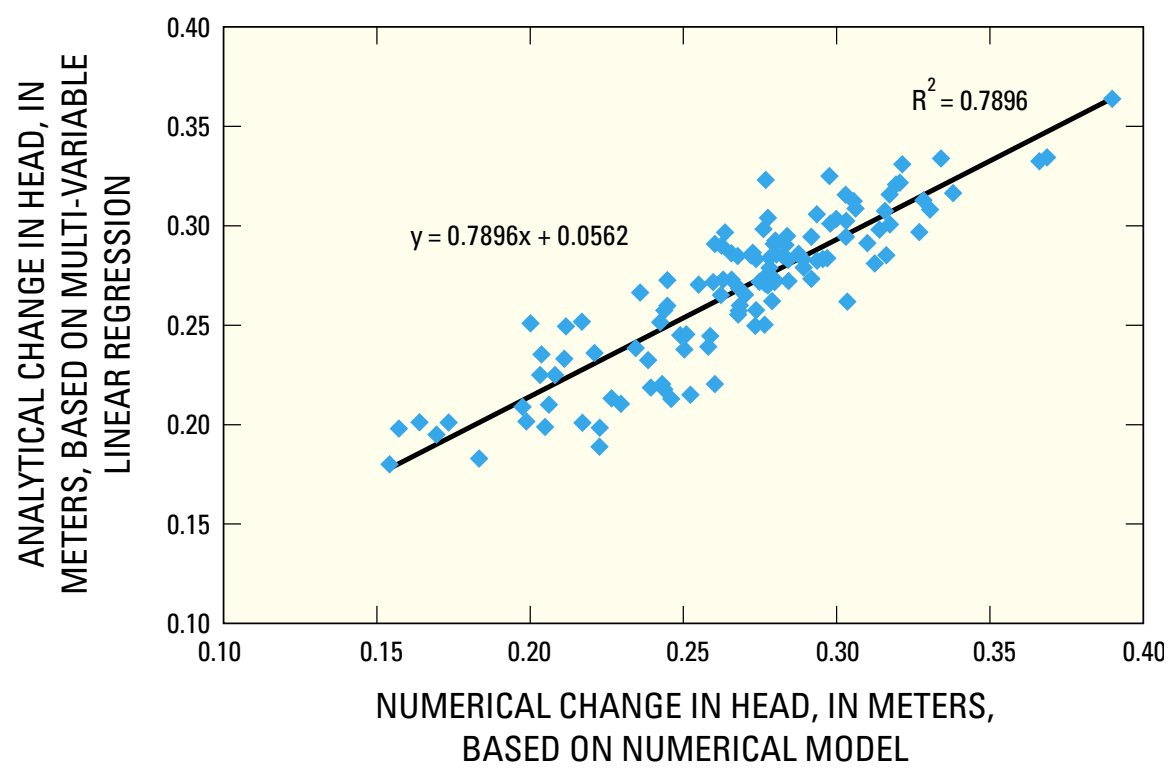

Figure 38. Observed and simulated difference in heads between observation wells using rainfall, pumpage, and change in upstream and downstream canal stage in a multivariate regression. $R^{2}$ is the coefficient of determination. 
change in predicted head (using these parameters) based on numerical and analytical model results. An $\mathrm{R}^{2}$ value of 0.7896 is a relatively good fit, indicating that the simulated change in head near the well field is affected by all three parameters. The $\mathrm{R}^{2}$ values decrease substantially when rainfall, pumpage, or canal stage change is removed from the multivariate regression.

The 1-ft $(0.3048-\mathrm{m})$ rule may not be useful in evaluating movement of the saltwater interface in a 10 -year period because a definitive relation could not be found when comparing the water-level differences between two simulated observation wells near the well field and saltwater interface movement at the front. Specifically, the primary factors affecting ground-water heads are somewhat different from those affecting saltwater interface movement. Head differences between simulated observation wells near the well field are affected by pumpage, the change in head between the upstream and downstream canal, and rainfall. In contrast, regression analyses indicated that rainfall has the greatest effect on saltwater interface movement near the well field. Near the canal, linear regression analyses indicated that the difference between the upstream and downstream canal stage has the greatest effect on saltwater interface movement.

The regression analyses indicated that saltwater interface movement near the well field and far from the canal in the 10-year scenario is affected mostly by rainfall. Rainfall would likely cause increased or decreased flow in the vertical direction. Canal stage change affects saltwater interface movement near the canal, also causing increased or decreased flow in the vertical direction. A change in head between two separate simulated observation wells would cause increased or decreased flow in the horizontal direction, and this does not appear to affect short-term saltwater interface movement. Based on these results, vertical rather than horizontal flow seems to have a greater effect on short-term (less than 10 years) movement of the saltwater interface.

\section{SEAWAT Model Evaluation Scenarios}

After completion of the 10-year (1990-99) model simulation, evaluation scenarios were run to test the effects of environmental changes such as canal stage, drought, and sea-level rise. These scenarios aid in evaluating the timing and response of the saltwater interface to changes in hydrologic stresses.

\section{Canal Stage}

To evaluate the effect of a change in canal stage on saltwater intrusion, the constant-head cells representing the upstream canal stage and the GHB cells representing the Everglades were decreased $1 \mathrm{ft}(0.3048 \mathrm{~m})$ in the model. All other model parameters remained unchanged from the 10-year simulation. The simulation began with the ending salinity concentrations from the original 10 -year simulation. After five runs (or 50 years) with initial salinity concentrations for each run set as the ending salinity concentrations from the previous run, the model reached dynamic equilibrium with respect to salinity concentration (fig. 39A). The boundary heads were then returned to the original values, increased $1 \mathrm{ft}(0.3048 \mathrm{~m})$, and the model was run again to dynamic equilibrium, which took about 90 years (fig. 39B).

When the upstream canal stage is increased or decreased by $1 \mathrm{ft}(0.3048 \mathrm{~m})$, the saltwater interface immediately responds in cells G, E, and F closest to the canal (fig. 40A). Closer to the well field, however, the saltwater interface response is much slower. Cells A and B show no short-term response because the cell distances are relatively far from the canal and any tidal stress, and the vertical positions of the cells are in the lower part of the surficial aquifer system, which is less permeable than the Biscayne aquifer. Salinity concentrations in cells A and B take 50 and 90 years, respectively, to reach equilibrium after lowering and raising the stage (fig. 40A). Upconing is evident in row 1 (fig. 41) after 50 years. The $250-\mathrm{mg} / \mathrm{L}$ chloride concentration contour has not reached the well field, but the contour is much closer to the pumping wells than in the original 10-year simulation.

Based on results of the 140-year canal stage simulation, an analysis was performed on the effectiveness of the 1 -ft $(0.3048-\mathrm{m})$ rule. The two simulated observation wells in the 10-year simulation (fig. 33) are used to evaluate the 1 -ft $(0.3048-\mathrm{m})$ rule. To filter the short-term fluctuations and highlight the long-term effects, a moving average of the previous 10 years was calculated for the simulated head difference between the simulated observation wells and the simulated salinity concentration at the toe. Although the 10 -year moving average of the head difference in the model never exceeds $1 \mathrm{ft}$ or $0.3048 \mathrm{~m}$ (fig. 42), a relation between saltwater interface movement near the well field and the canal stage change after 50 years is apparent in this simulation. The head difference between simulated observation wells increases immediately after the increase in canal stage. About 5 years pass, however, before the salinity concentration at the seaward simulated observation well begins to decrease as a result of the increase in canal stage. A possible explanation is that the increase in head difference between the two simulated observation wells affects horizontal pressure on the saltwater interface near the well field. The horizontal influence on the saltwater interface may require a longer response time than the short-term vertical effects, such as rainfall. More than 60 years pass before salinity concentrations at the toe reach dynamic equilibrium after the change in upstream canal stage. Therefore, an evaluation of head differences between simulated observation wells can predict saltwater interface movement over long periods of time (greater than 10 years), but model results revealed that meeting the $1-\mathrm{ft}(0.3048-\mathrm{m})$ rule is unlikely. 

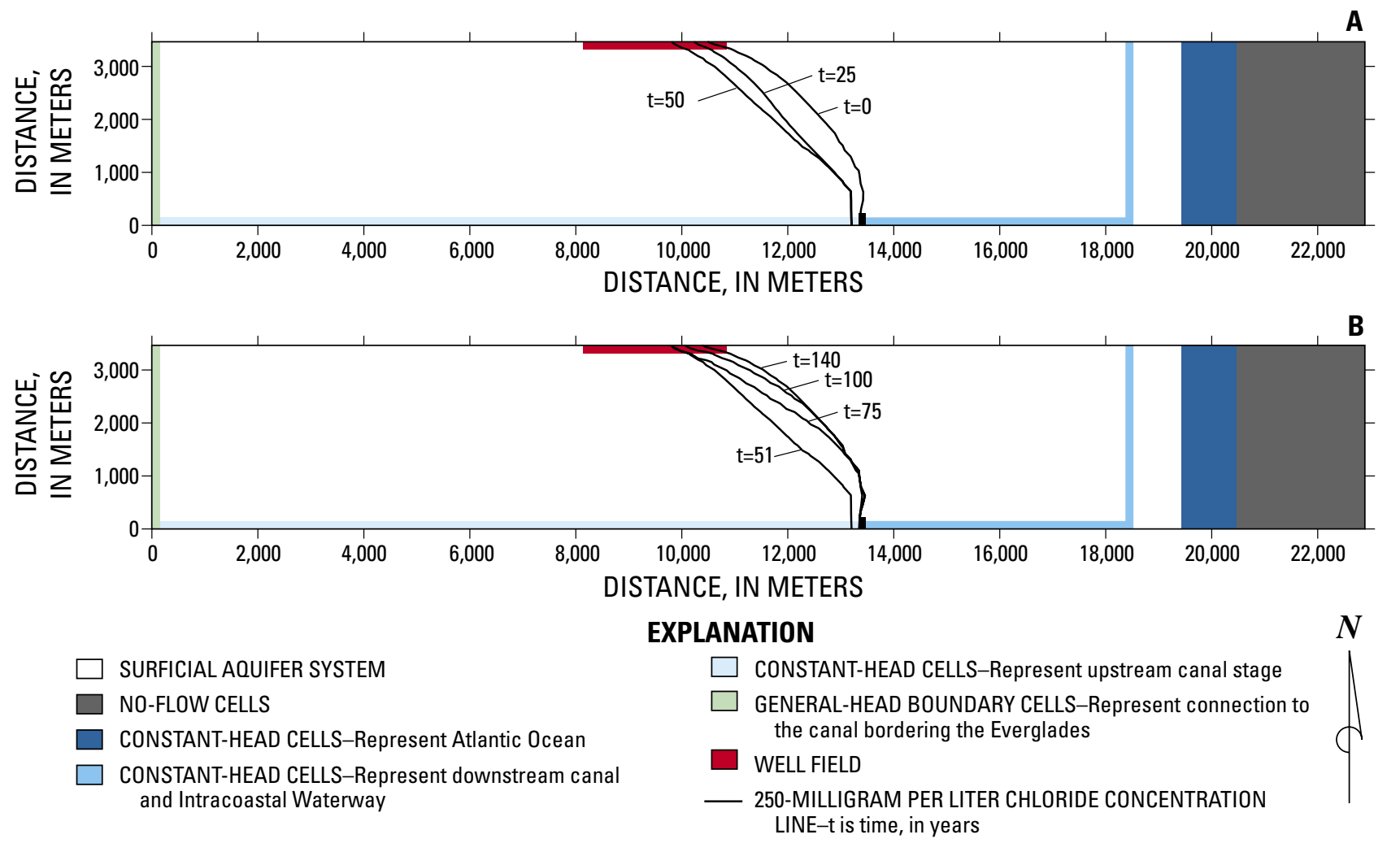

Figure 39. Map views showing toe movement at the base of the surficial aquifer system in the model over time for the simulation representing canal stage change. View A shows inland movement of the 250-milligram per liter chloride concentration contour after the upstream canal is lowered 1 foot (0.3048) meter. View B shows seawater movement of the 250-milligram per liter chloride concentration contour after upstream canal stage is returned to its original level.

\section{Drought with Increased Ground-Water Withdrawals}

The 10-year model was modified to include the effects of a hypothetical 3-year drought and an associated increase in ground-water withdrawals at the well field. Rainfall data collected in the Five Ash/Prospect Well Field area from January to December 1988 (drought period) were used for the first 3 years (1990-92) of the 10-year simulation (fig. 43A) to represent a hypothetical drought in southeastern Florida. From May 1993 to April 1994, the pumping rate was the highest at the well field (fig. 43B); one half of this rate was used for the first 3 years of the simulation. The selected time periods represent the "worst drought" conditions, with the least amount of rainfall and highest amount of pumpage in the last 20 years.

Initial results from the model indicated that a 3-year drought with increased pumpage appears to have little effect on the overall horizontal movement of the saltwater interface after 10 years (fig. 44). There is an overall increase in salinity concentration in the simulated Biscayne aquifer during the first 7 years of the simulation (fig. 45A-C). Salt concentrations in most observation cells (for example, C, E, and F) in the simulated Biscayne aquifer return to their initial values during the last 3 years, and are similar to salinity concentrations observed at the end of the original 10-year model (fig. 46). The salt concentration increases in the lower part of the surficial aquifer system seem to be a lagged result (fig. 45A-C, cells A and D) from the increased pumpage and drought. The saltwater interface in the lower part of the surficial aquifer system does not return to initial concentrations at the end of the 10 years, suggesting a long-term effect on the interface due to the drought and increased well-field withdrawals. Cell $\mathrm{G}$ at the base of the surficial aquifer system does not behave like cells $\mathrm{A}$ and $\mathrm{D}$, probably because cell $\mathrm{G}$ is located farthest from the well field and beneath the control structure. Therefore, cell $\mathrm{G}$ is probably affected by changes in canal stage rather than increased pumpage.

Model results indicated that saltwater is located beneath a small part of the well field (fig. 46). Upconing is evident in row 1 near the well field at the end of 10 years, but is not 


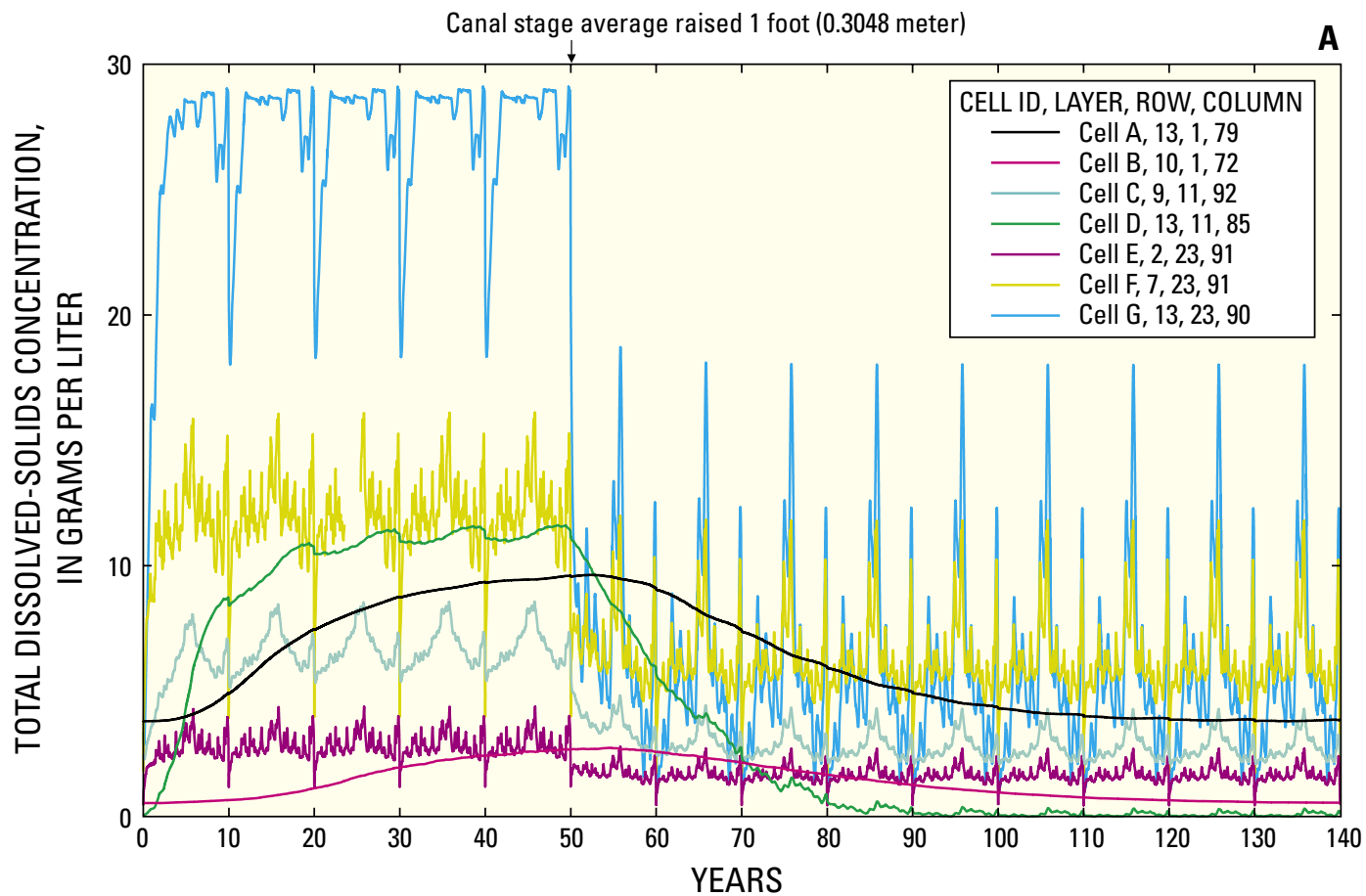

B

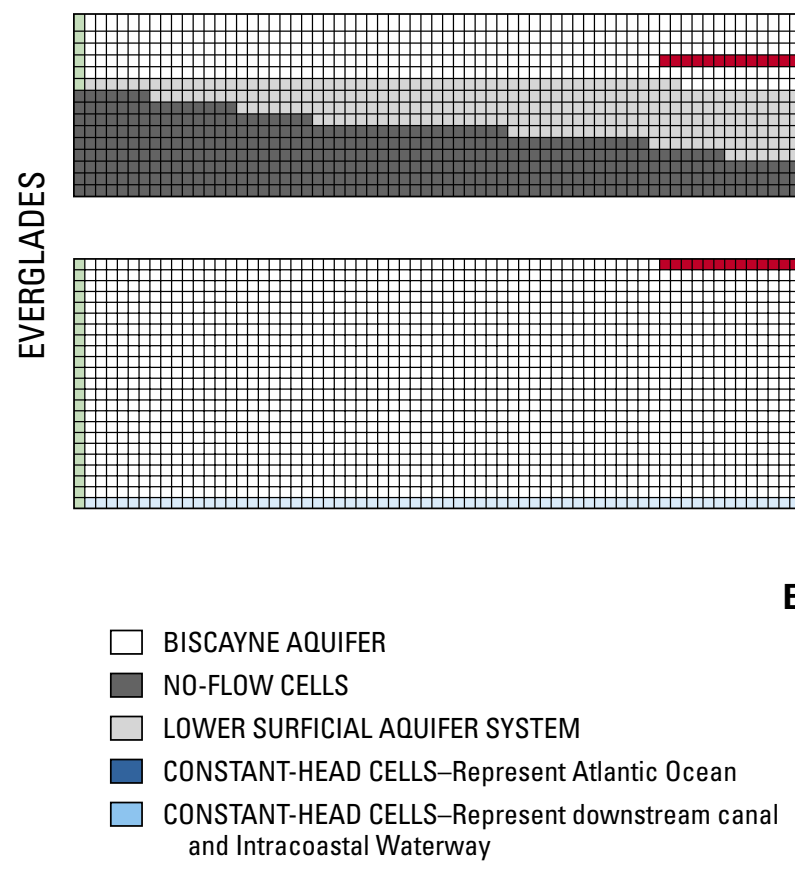

EXPLANATION

$N$

Figure 40. (A) Total dissolved-solids concentrations (at observation cells) for the canal stage change scenario, (B) cross-sectional vie observation cell. The color used for each observation cell is identical in the graph and grids. 


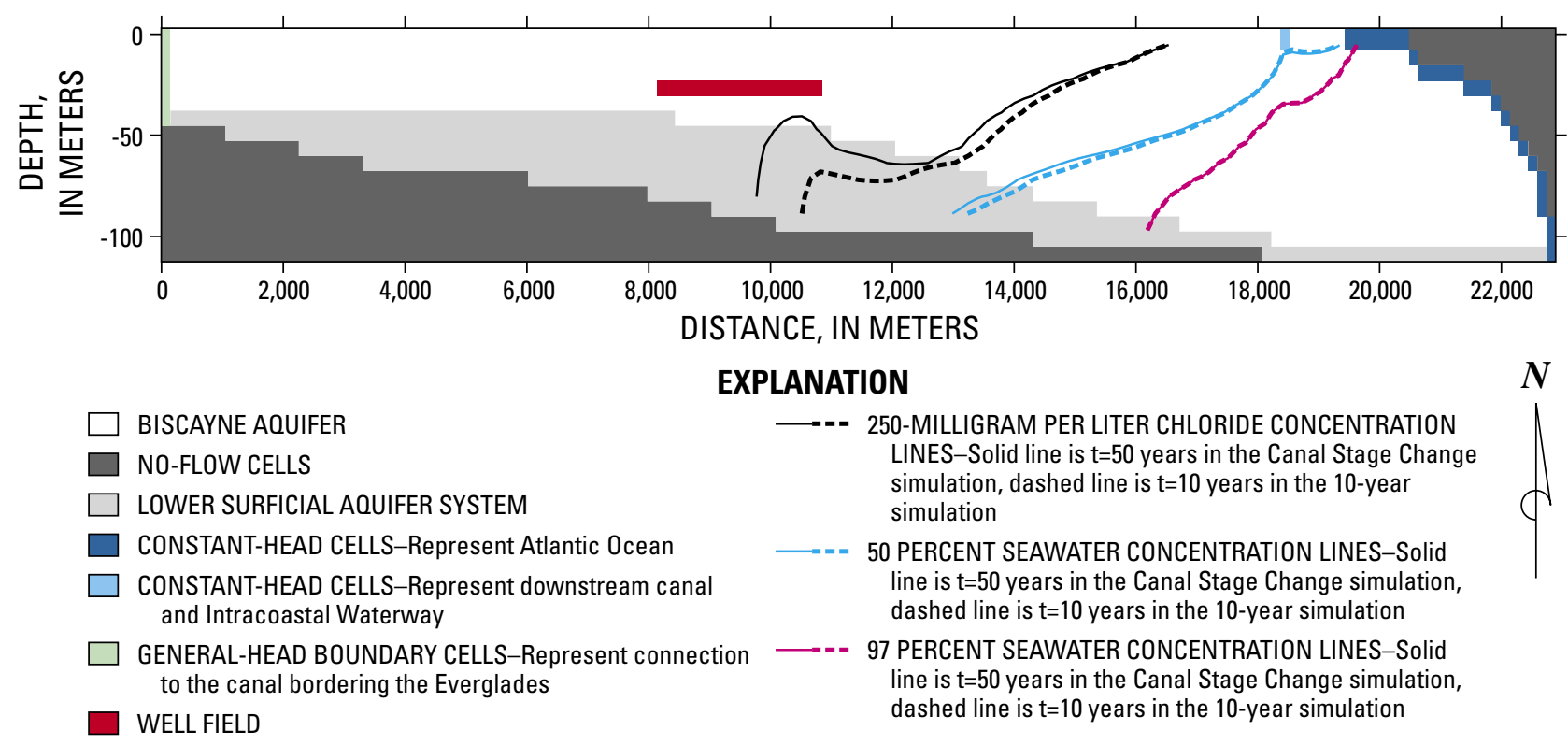

Figure 41. Cross-sectional view through row 1 (close to the well field) depicting the 250-milligram per lither chloride concentration contour and the 50- and 97-percent seawater contours 50 years after the canal stage is lowered 1 foot (0.3048 meter).

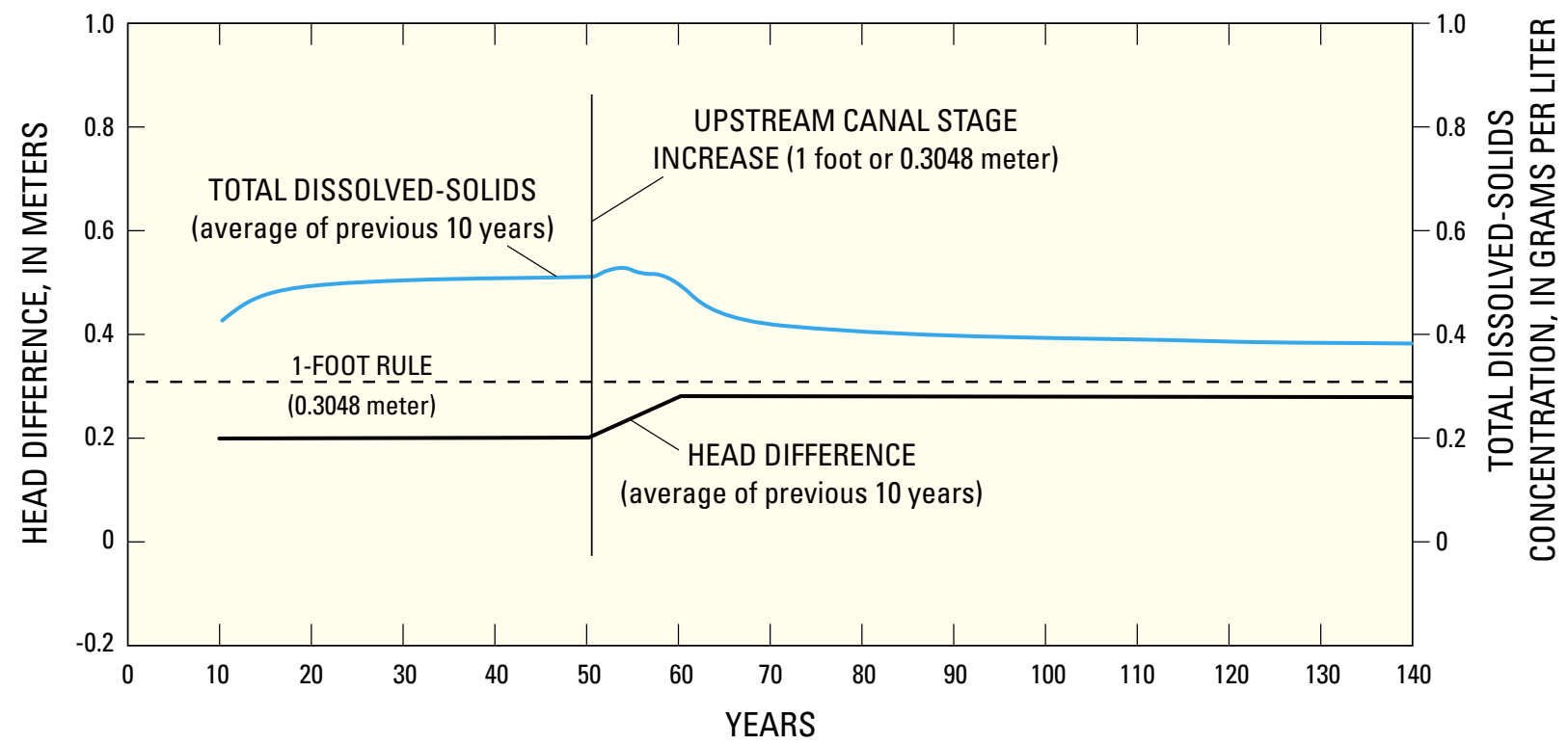

Figure 42. Evaluation of the 1 -foot (0.3048-meter) rule for the canal stage change scenario. 

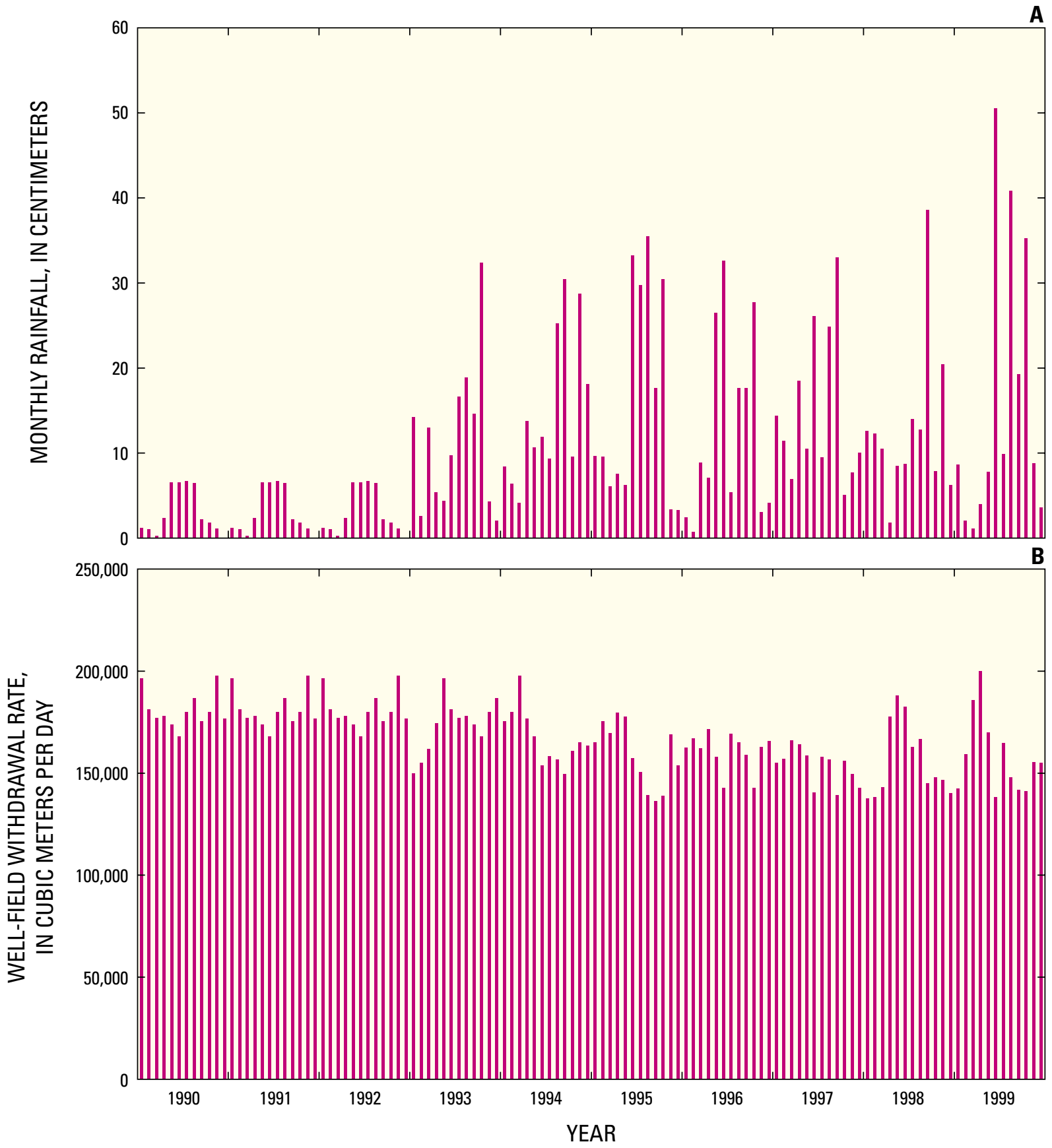

Figure 43. (A) Rainfall and (B) half the pumpage for the 10-year (1990-99) simulation modified with 3 years of drought and 3 years of increased pumpage at the beginning of the simulation. Pumpage data for the 1990-92 simulated drought is for the Five Ash/Prospect Well Field from May 1993 to April 1994; data for 1993-99 is half of the actual pumpage for the Five Ash/Prospect Well Field. 


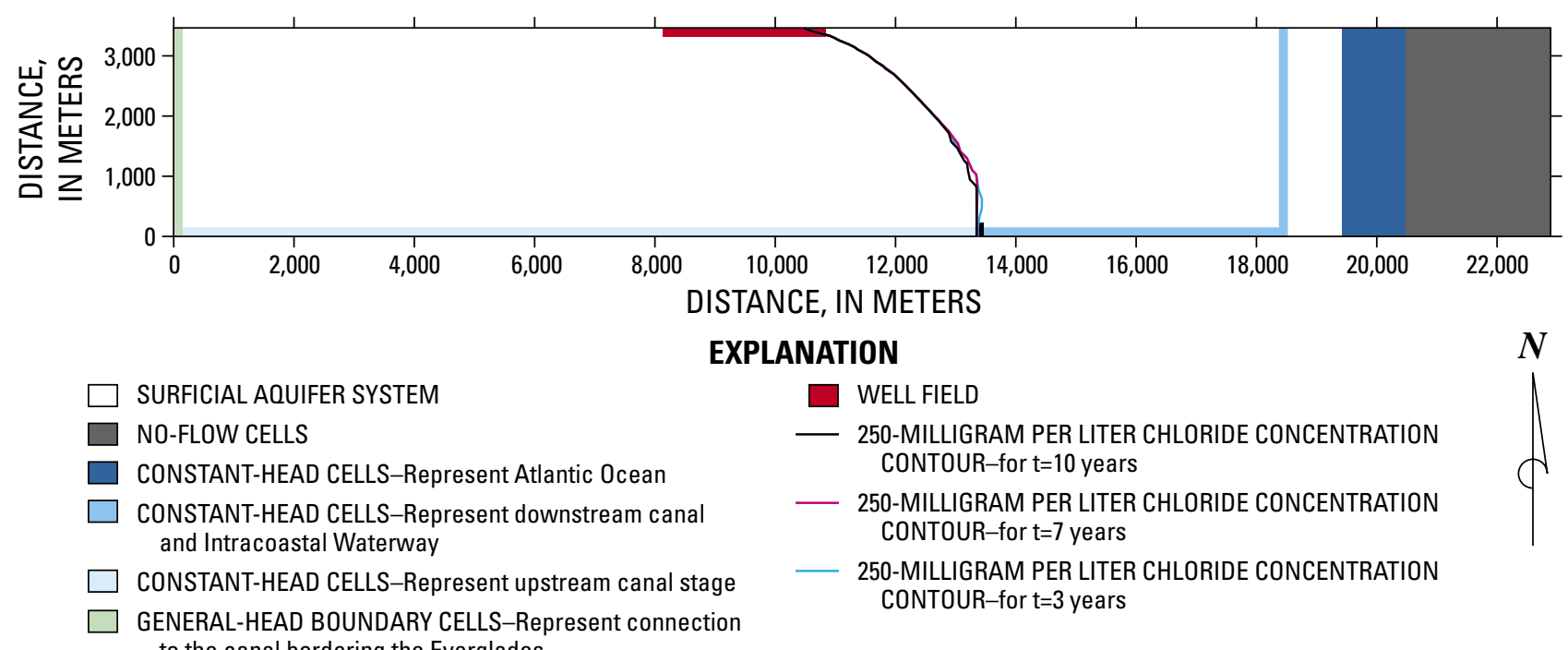

Figure 44. Map view showing toe movement at the base of the surficial aquifer system in the model over time for the simulation representing decreased rainfall and increased pumpage.

much different from the results of the 10-year simulation. The 250-mg/L chloride concentration contour has not reached the pumping wells in the well field. Results from the drought simulation are similar to the original 10-year simulation, with only minimal increase in upconing during the drought simulation.

The two simulated observation wells in the original 10-year model (fig. 33) are used in this scenario to evaluate the $1-\mathrm{ft}(0.3048-\mathrm{m})$ rule. Results from this scenario rarely meet this rule during the first 5 years of the 10-year simulation (fig. 47). During the last 5 years of the simulation, the $1-\mathrm{ft}(0.3048-\mathrm{m})$ rule is met more often. The head difference between the two simulated observation wells is always positive. (The simulated observation well farther inland, well $\mathrm{X}$, is always higher.) The overall head difference between the two simulated observation wells during the first 3 or 4 years (fig. 47) is less than that for the original 10-year model (fig. 34). The salinity concentrations in the drought simulation are higher during the first 6 years than during the first 6 years of the 10-year simulation (figs. 34 and 47). By the end of the drought simulation, salinity concentrations at the simulated observation well on the saltwater interface are about the same as those for the 10-year simulation. The two runs having similar concentrations at the end indicated that a 3-year drought will not have long-term effects on the location of the saltwater interface.

The previous linear regression analysis of rainfall and change in total dissolved-solids concentration (fig. 36) indicated that the salinity concentration increases during the drought simulation are directly related to the lack of rainfall. The decrease in head difference probably results from the increase in pumpage, and to a lesser degree, the decrease in rainfall.

\section{Sea-Level Rise}

Sea level is predicted to rise between 9 and $88 \mathrm{~cm}$ by the year 2100 (Intergovernmental Panel on Climate Change, 2001). To test the effect of sea-level rise, water levels downstream in the canal, Intracoastal Waterway, and ocean were increased slightly $(0.402 \mathrm{~cm})$ each month for 10 consecutive 10 -year simulations. The total sea-level rise simulated in the model is $48.26 \mathrm{~cm}$, over 100 years (fig. 48). After 100 years, the increase in water levels in the downstream canal, Intracoastal Waterway, and ocean was halted, and the simulation was repeated another 6 times (60 years) until salinity concentrations reached equilibrium. All other parameter values in this simulation were the same as for the 10-year simulation.

Results from the model indicated that the saltwater interface moves inland about $1.5 \mathrm{~km}$ at the base of the surficial aquifer system after 160 years with a $48.26-\mathrm{cm}$ increase in sea level (fig. 49). All of the observation cells show the effects of sea-level rise. The saltwater interface response to the sea-level rise is almost immediate at observation cells $\mathrm{F}$ and $\mathrm{G}$ near the canal (fig. 50A-C). The response is much slower, however, in observation cells A and B near the well field. The salinity concentrations at observation cells A and B take about 60 years to reach equilibrium after the end of the sea-level rise. 

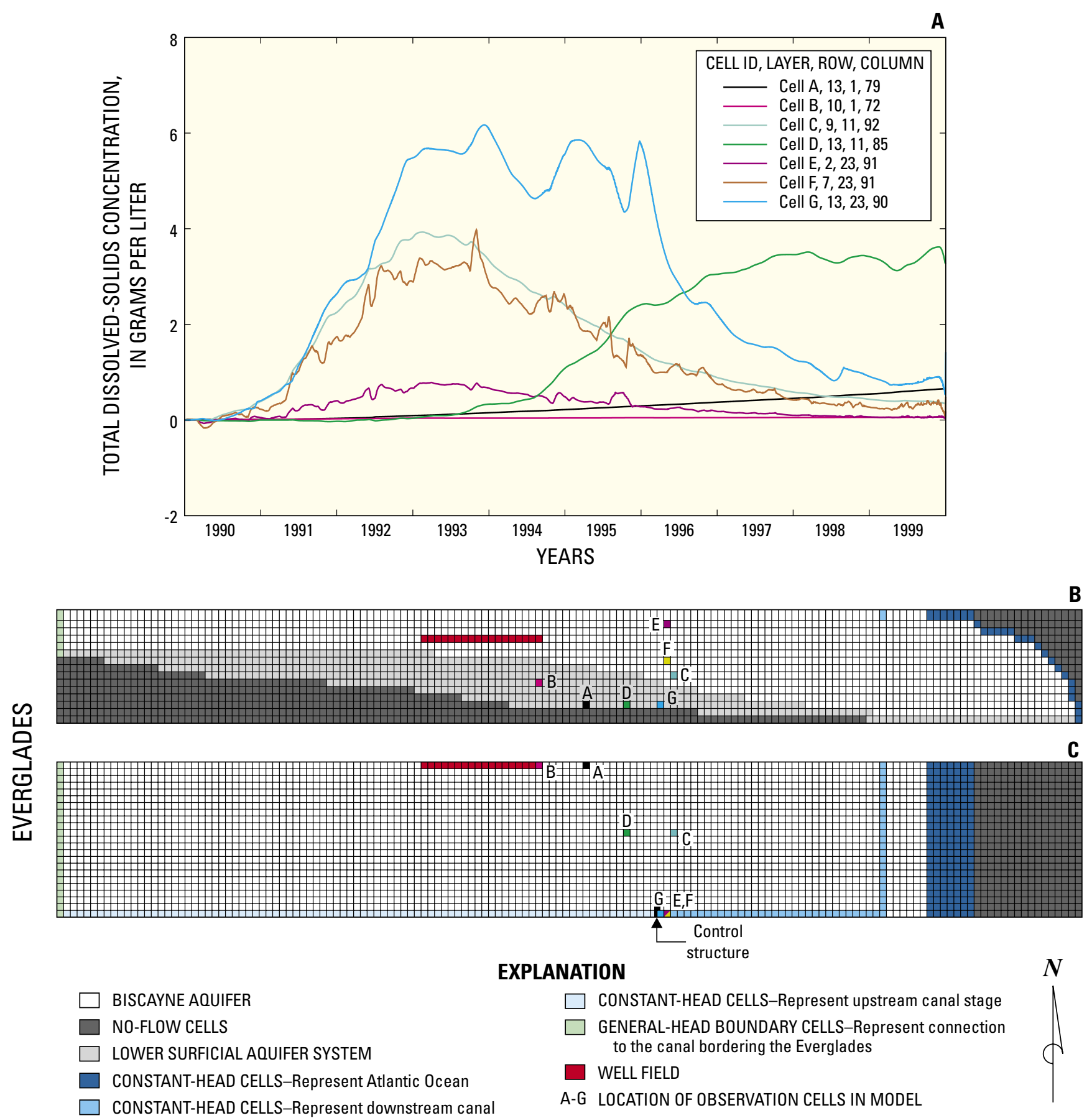

Figure 45. (A) Total dissolved-solids concentration during the simulated drought subtracted from the 10-year base simulation, areal location of each observation cell. The color used for each observation cell is identical in the graphs and the grids. 


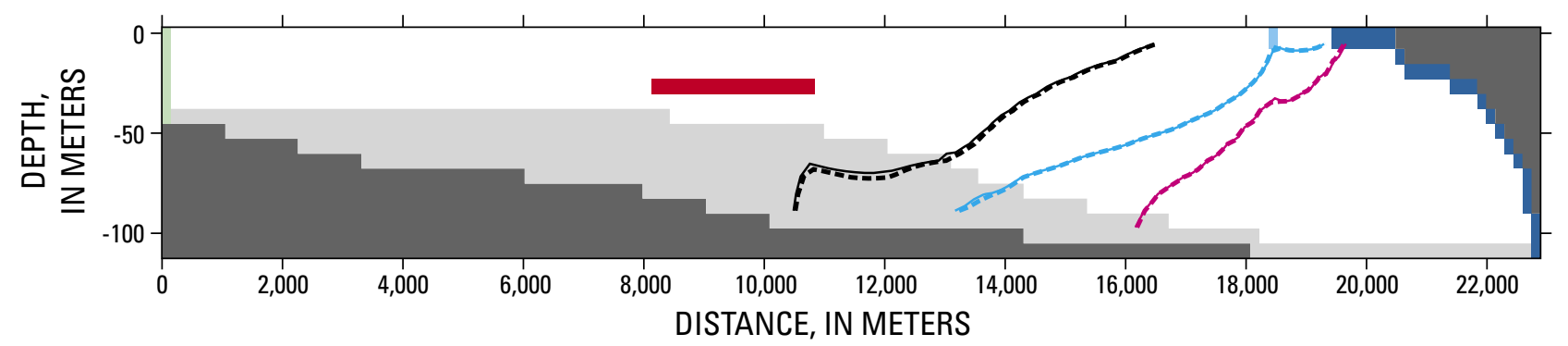

EXPLANATION

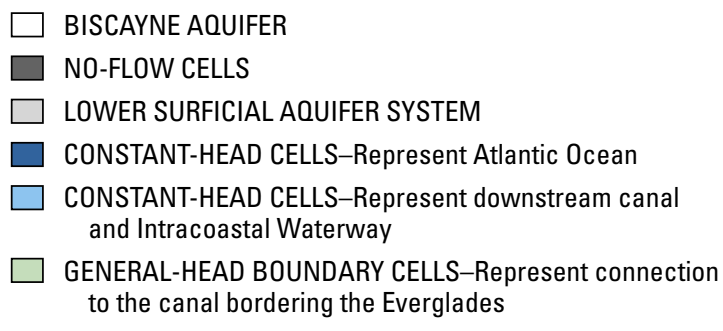

WELL FIELD
--- 250-MILLIGRAM PER LITER CHLORIDE CONCENTRATION LINES-Solid line is $t=10$ years in the Drought/Increased pumpage simulation, dashed line is $t=10$ years in the 10 year simulation

---- 50 PERCENT SEAWATER CONCENTRATION LINES-Solid line is $\mathrm{t}=10$ years in the simulated drought, dashed line is $\mathrm{t}=10$ years in the 10 -year simulation

---- 97 PERCENT SEAWATER CONCENTRATION LINES-Solid line is $\mathrm{t}=10$ years in the simulated drought, dashed line is $t=10$ years in the 10 -year simulation

Figure 46. Cross-sectional view through row 1 depicting the 250 -milligram per liter chloride concentration contour and the 50- and 97-percent seawater contours based on the simulated drought scenario.

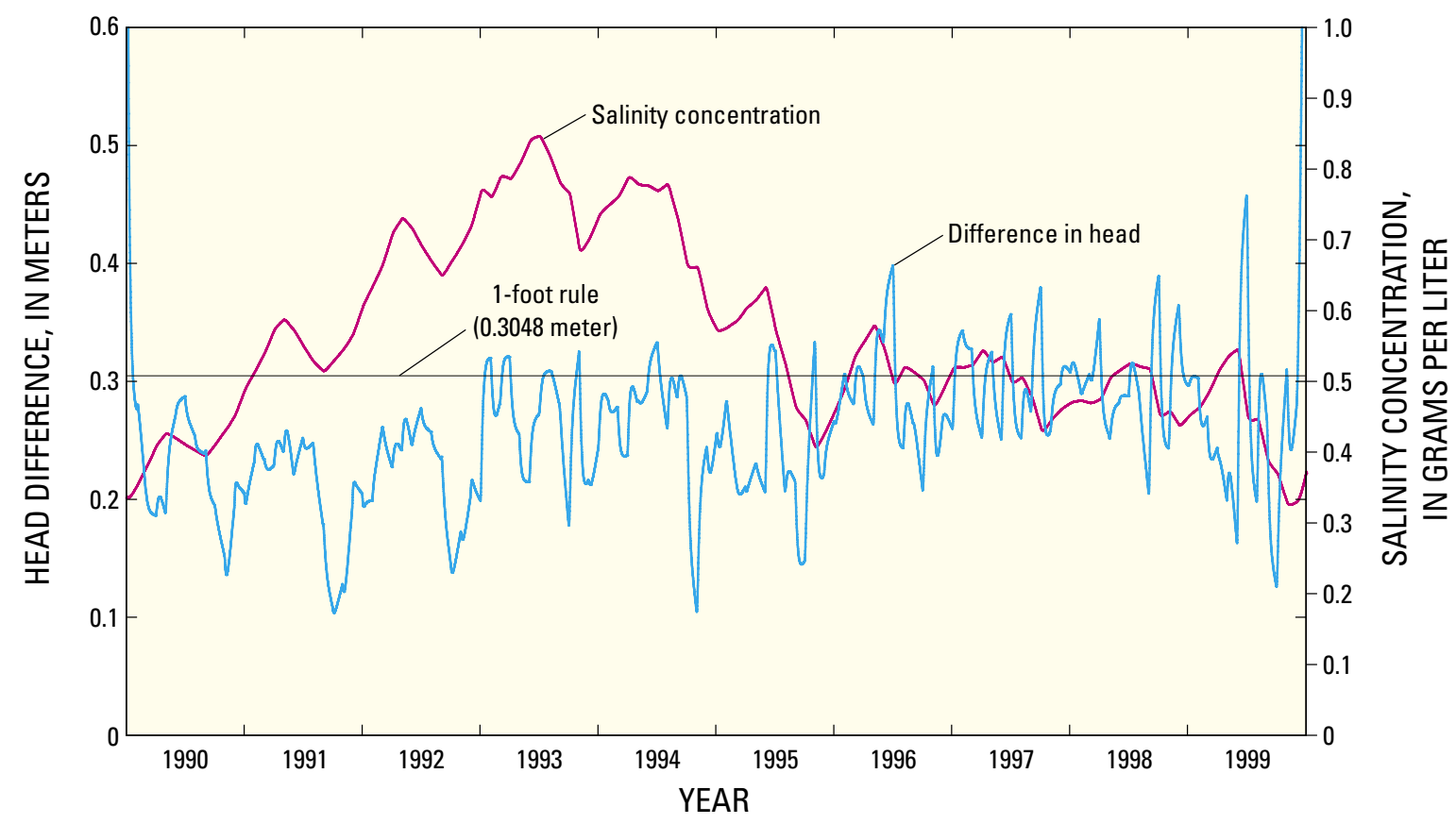

Figure 47. Evaluation of the 1-foot (0.3048-meter) rule for the simulated drought scenario. 


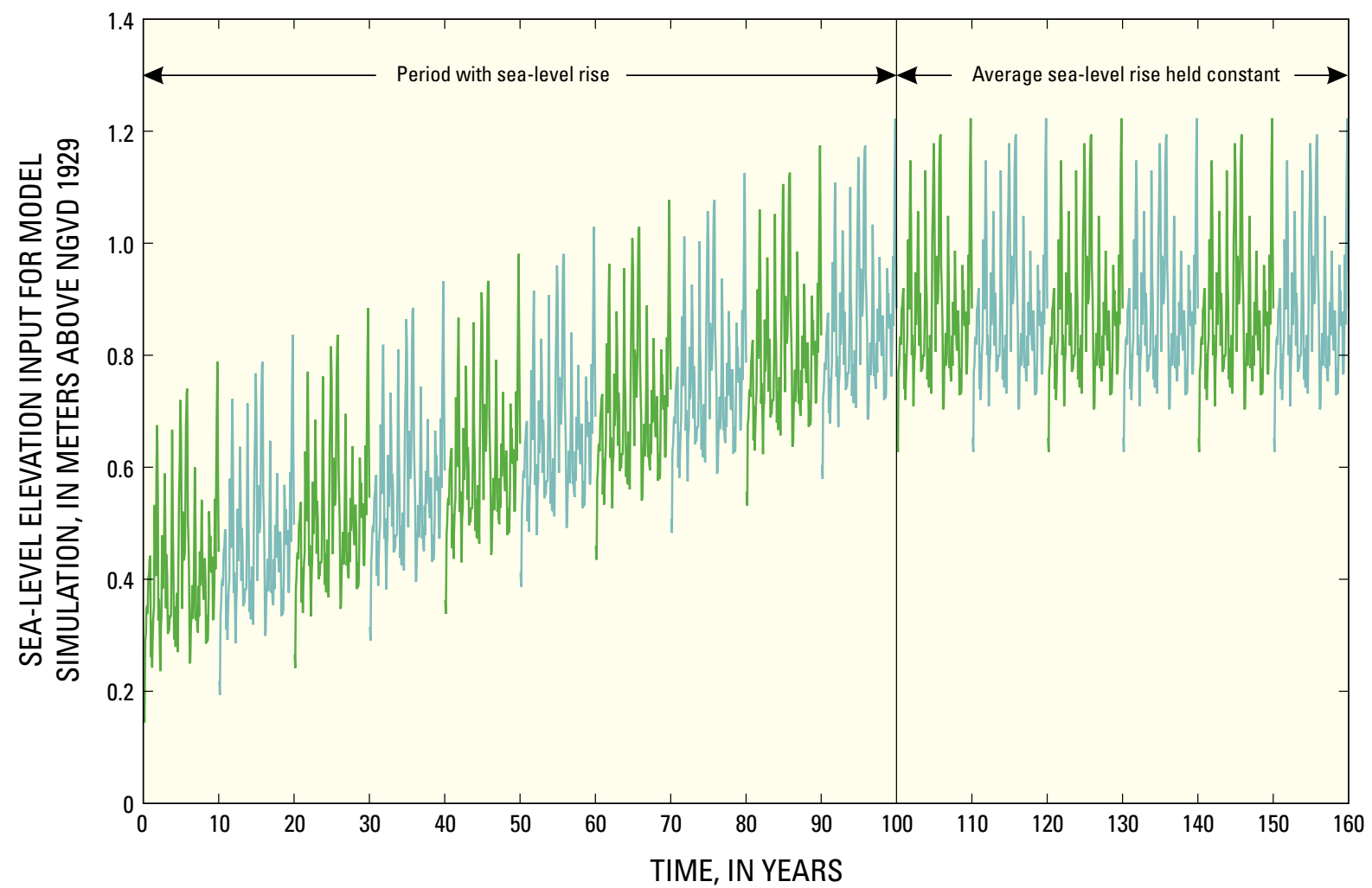

Figure 48. Sea-level elevation input used for the sea-level rise evaluation scenario.

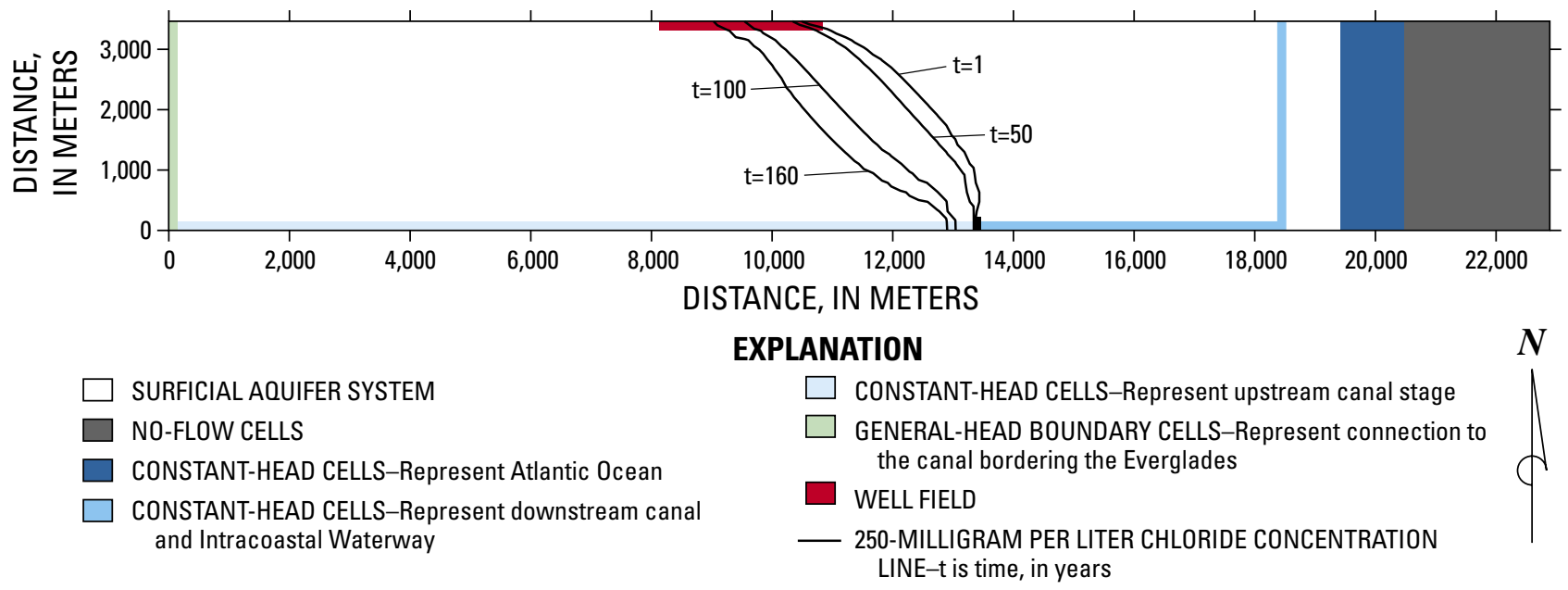

Figure 49. Map view showing inland toe movement at the base of the surficial aquifer system in the model over time for the simulation representing effect of sea-level rise. 

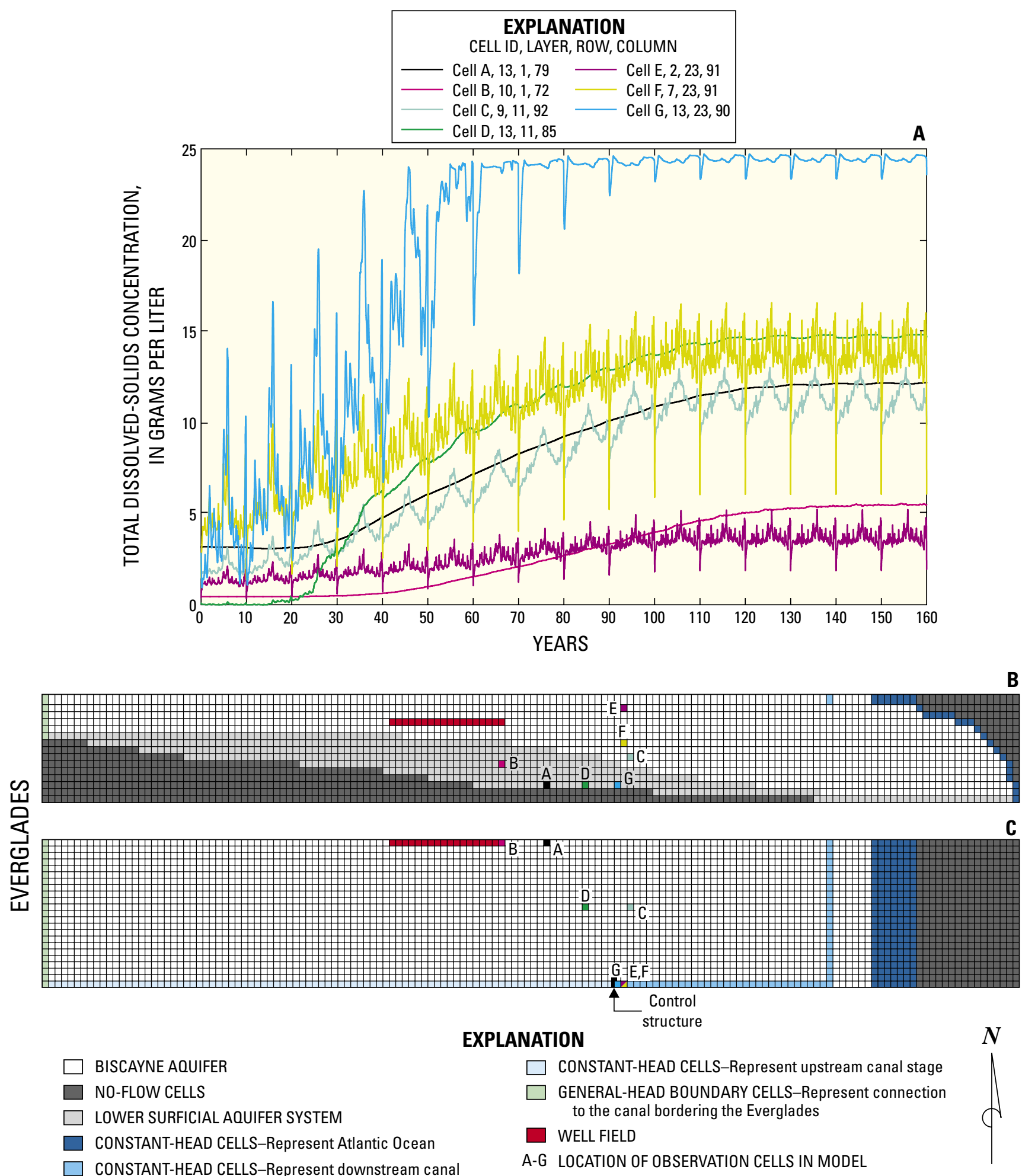

Figure 50. (A) Total dissolved-solids concentrations at observation cells in the sea-level rise simulation, (B) cross-sectional view of the model depicting the depth of each observation cell, and (C) map view of the model depicting the areal location of each observation cell. The color used for each observation cell is identical in the graph and grids. 


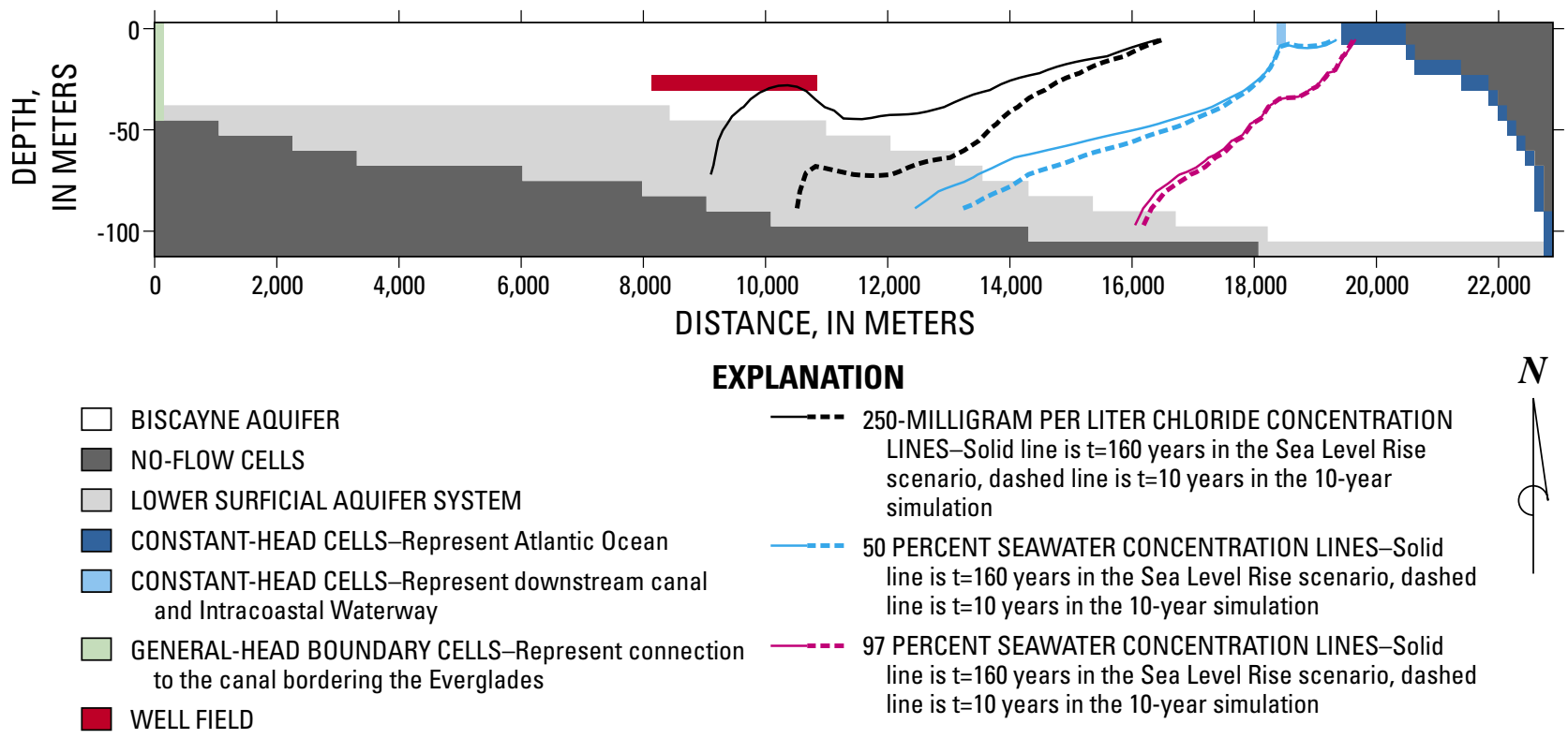

Figure 51. Cross-sectional view through row 1 depicting the 250-milligram per liter chloride concentration contour and the 50- and 97-percent seawater contours based on the seal-level rise scenario.

Results indicated that upconing occurs beneath the well field (fig. 51). Water with a $250-\mathrm{mg} / \mathrm{L}$ chloride concentration is drawn into the well field, exceeding drinking-water standards according to the U.S. Environmental Protection Agency (1977).

The two simulated observation wells ( $\mathrm{X}$ and $\mathrm{Y}$ ) in the 10-year model (fig. 33) are used in this scenario to evaluate the 1 -ft $(0.3048-\mathrm{m})$ rule. The 10 -year moving average of the head difference between wells never meets the $1-\mathrm{ft}(0.3048-\mathrm{m})$ rule (fig. 52). The relation between saltwater interface movement near the well field and head difference between simulated observation wells $\mathrm{X}$ and $\mathrm{Y}$ is evident (fig. 52). Overall, the head difference decreases between the simulated observation wells and salinity increases at the saltwater interface front. Therefore, head differences between wells can be used to predict saltwater interface movement over long periods of time; however, $1 \mathrm{ft}(0.3048 \mathrm{~m})$ is too large of a head difference for prediction.

\section{Sensitivity Analysis}

A detailed sensitivity analysis with the 10-year simulation helped identify the parameters, such as hydraulic conductivity, porosity, and transverse dispersivity, which substantially affect the movement of the saltwater interface. The approach involved testing model response (simulated salinity changes) to individual parameter change over a wide range of values.
Aquifer parameters that were evaluated in the Biscayne aquifer and the lower part of the surficial aquifer system include horizontal and vertical hydraulic conductivities, longitudinal and transverse dispersivities, porosity, and specific yield. Other parameters that were evaluated include evapotranspiration and recharge. Two simulated observation wells (P and $\mathrm{Q})$ were included (fig. 53) in each sensitivity run to evaluate the change in salinity concentration (or saltwater interface movement) that results from a specific parameter change. Both simulated observation wells are located at the front of the saltwater interface where well $\mathrm{P}$ is in the Biscayne aquifer and well Q is in the lower part of the surficial aquifer system. Simulated salinity did not change with vertical hydraulic conductivity; therefore, no illustration is presented for the comparison.

For the first sensitivity runs, the horizontal hydraulic conductivities of the Biscayne aquifer and the lower part of the surficial aquifer system were increased or decreased by 50 percent in separate simulation. A change in the horizontal hydraulic conductivity of the Biscayne aquifer affects the saltwater front location in the Biscayne aquifer and in the lower part of the surficial aquifer system (fig. 54, well P). A change, however, in the horizontal hydraulic conductivity of the lower part of the surficial aquifer system affects only the front in the lower part of the surficial aquifer system (fig. 54, well Q) and has almost no effect on the front location in the Biscayne aquifer. Results from this run indicated that the model simulation is sensitive to horizontal hydraulic conductivities of the 


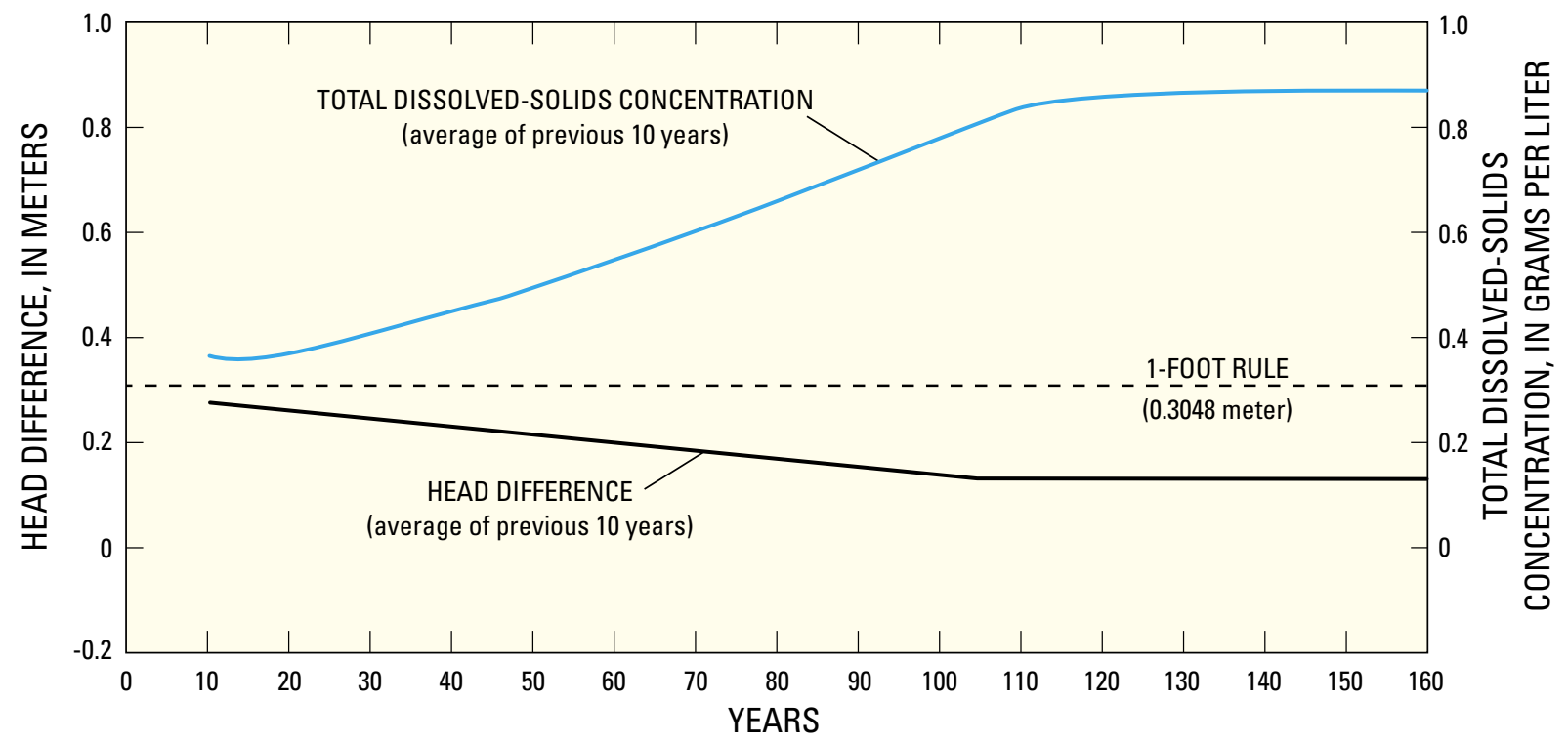

Figure 52. Elevation of the 1-foot (0.3048-meter) rule for the sea-level rise scenario.

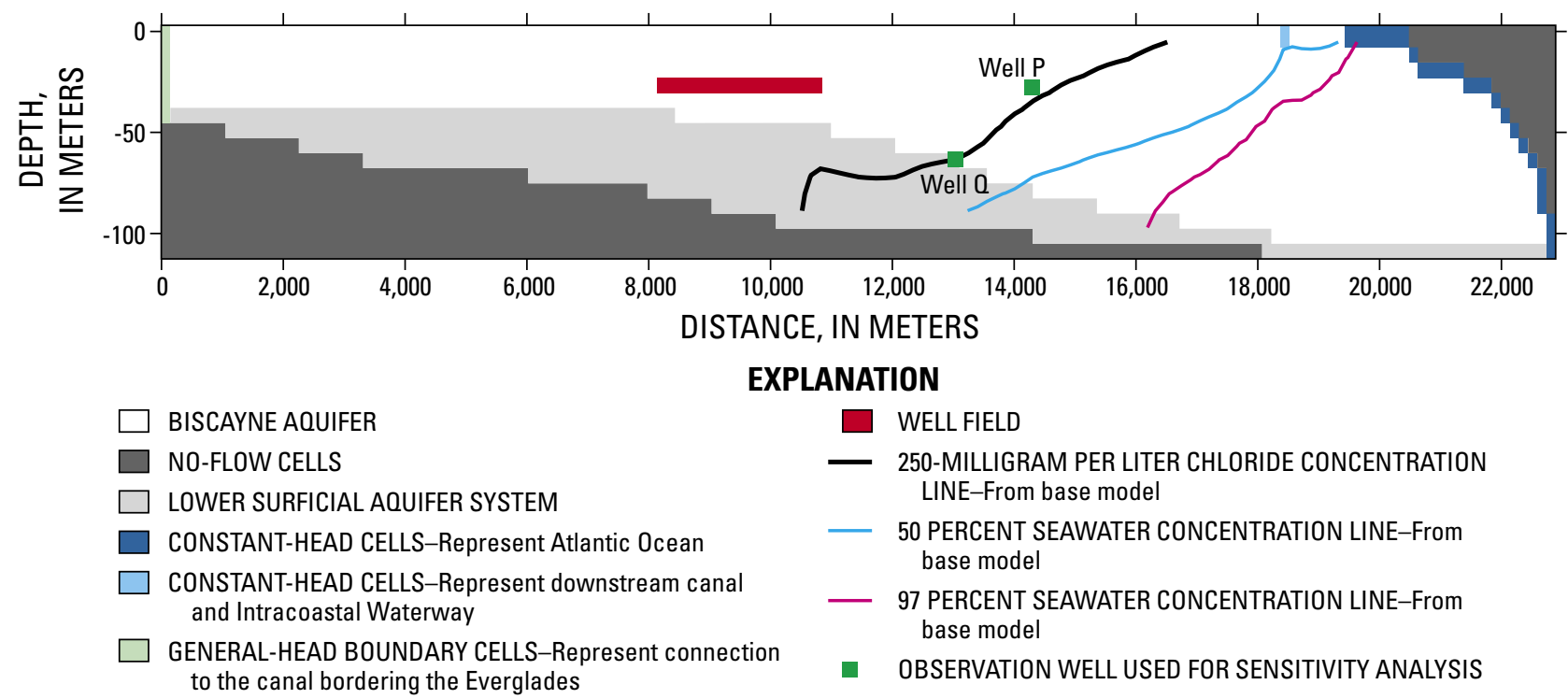

Figure 53. Cross-sectional view of simulated observation wells $P$ and $Q$ for a sensitivity analysis to evaluate the change in total dissolved-solids concentration. 


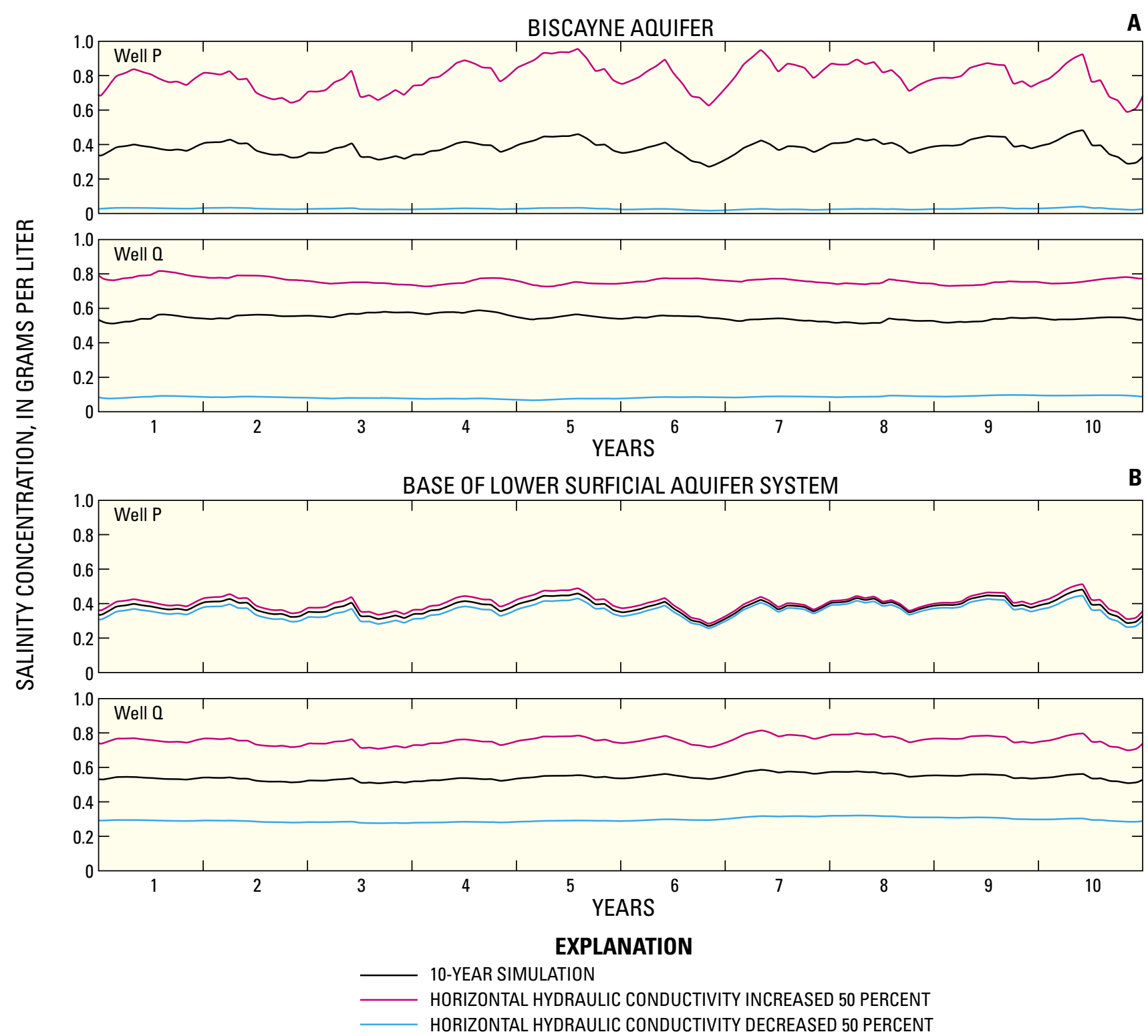

Figure 54. Total dissolved-solids concentration over time at simulated observation wells $\mathrm{P}$ and $\mathrm{Q}$, resulting from changes in horizontal hydraulic conductivity in the (A) Biscayne aquifer and (B) lower part of the surficial aquifer system.

Biscayne aquifer, and an overestimation of horizontal hydraulic conductivity will result in increased saltwater intrusion in the Biscayne aquifer and the lower part of the surficial aquifer system. Horizontal hydraulic conductivity changes in the lower part of the surficial aquifer system also affect the toe location in the lower part of the surficial aquifer system, but not in the Biscayne aquifer.

Hydrodynamic dispersion is a difficult process to estimate because of spatially variable hydraulic conductivity and spatially and temporally variable hydrologic boundary conditions. The simulation of hydrodynamic dispersion as a solutetransport process is further complicated because little detail can be included in a model to adequately represent the spatial variation in ground-water flow velocity. A dispersivity coefficient is assigned and used to control the amount of mixing due to variation in velocity that cannot be directly represented in the model. Longitudinal and transverse dispersivity values are included in the representative model to increase the mixing that could not be represented because of averaged boundary conditions and averaged hydraulic conductivities.

Sensitivity runs were conducted to evaluate the sensitivity of simulated salinity in the model relative to transverse and longitudinal dispersivities. These parameters were increased or decreased 50 percent, and the simulation was 


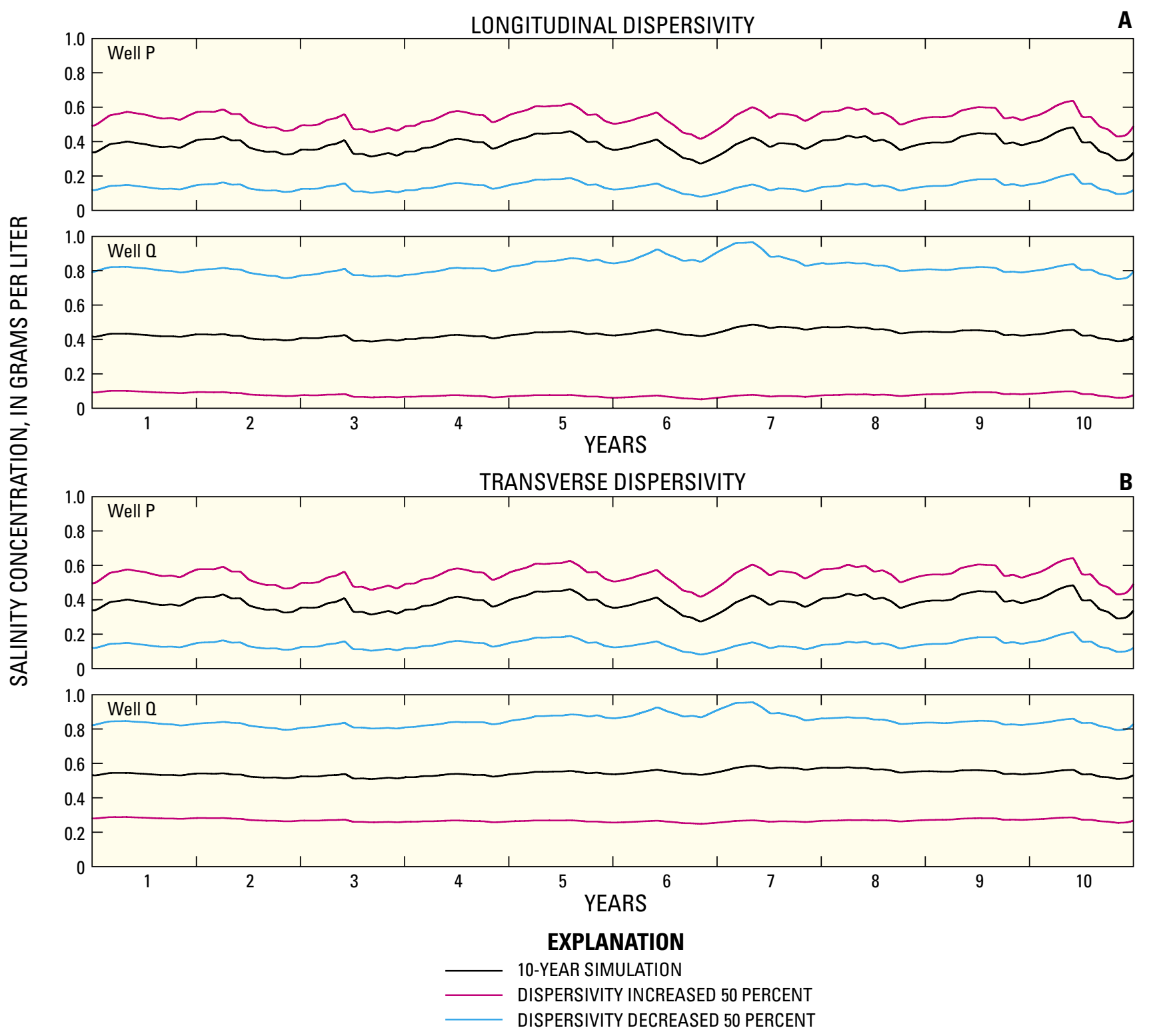

Figure 55. Total dissolved-solids concentration over time at simulated observation wells $P$ and 0 , resulting from changes in (A) longitudinal and (B) transverse dispersivities.

run to equilibrium. Results were similar for the increased longitudinal dispersivity and the increased transverse dispersivity (fig. 55, well P). The Biscayne aquifer shows increased salinity with increased dispersivity, and decreased salinity with decreased dispersivity. The saltwater interface, however, moves in opposite directions near land surface and at depth (fig. 55, Well Q; fig. 56). In the surficial aquifer system, increased dispersivity increases the simulated mixing, and the toe near the surface of the model moves slightly inland (fig. 56). With increasing depth and increased mixing, however, the toe moves seaward (fig. 56). This explains the different results between simulated observation wells $\mathrm{P}$ and $\mathrm{Q}$ in figure 55.
In summary, saltwater intrusion is decreased with an increase in transverse and longitudinal dispersivities (or an increase in mixing), and saltwater intrusion is increased with a decrease in transverse and longitudinal dispersivities. The results from these analyses revealed that the model is sensitive to longitudinal and transverse dispersivities.

Water moves fastest and solute travels farthest where aquifer porosities are low. This observation is apparent when the porosity is decreased 50 percent in the Biscayne aquifer represented by the model. Salinity fluctuations (fig. 57) are increased with a decrease in porosity, indicating that the higher velocities show greater saltwater interface movement landward 


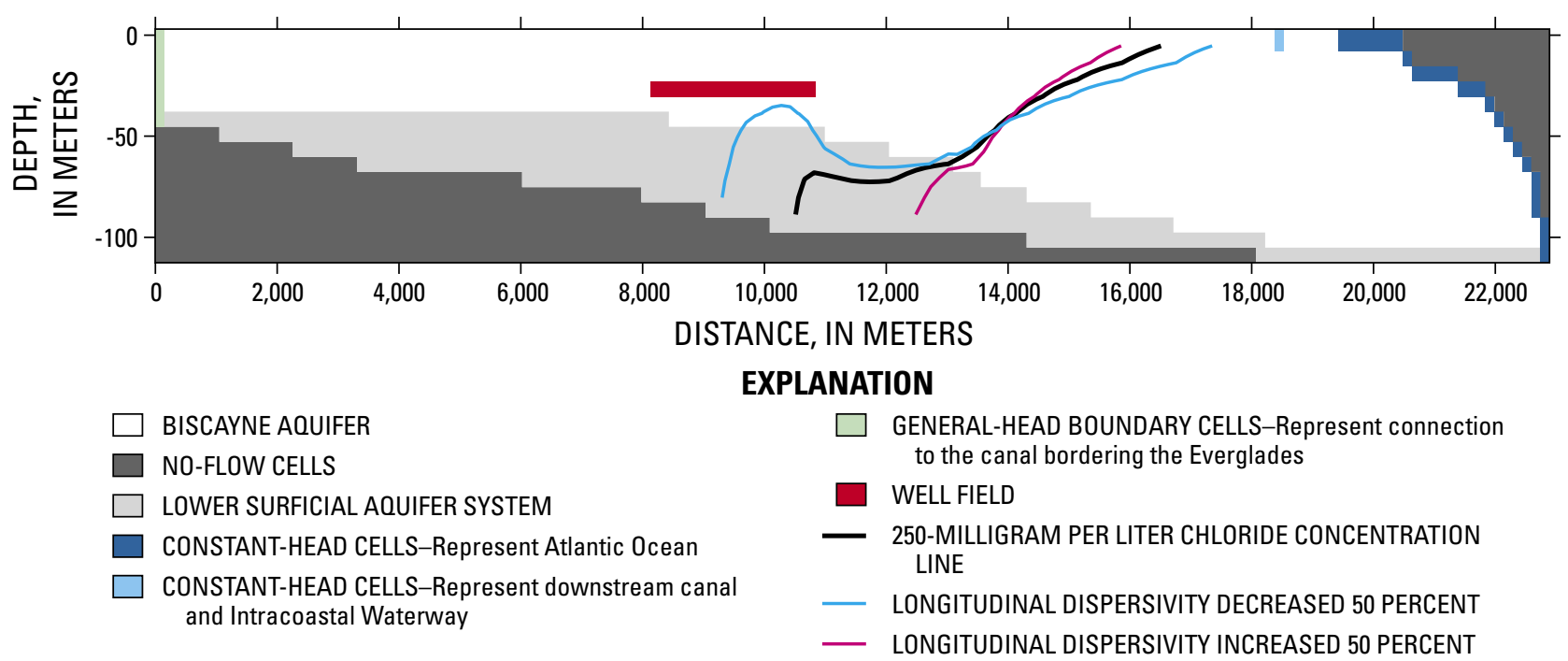

Figure 56. Cross-sectional view of model grid depicting the toe (250-milligram per liter chloride concentration contour) for the 10-year simulation, with longitudinal dispersivity increased and decreased 50 percent.

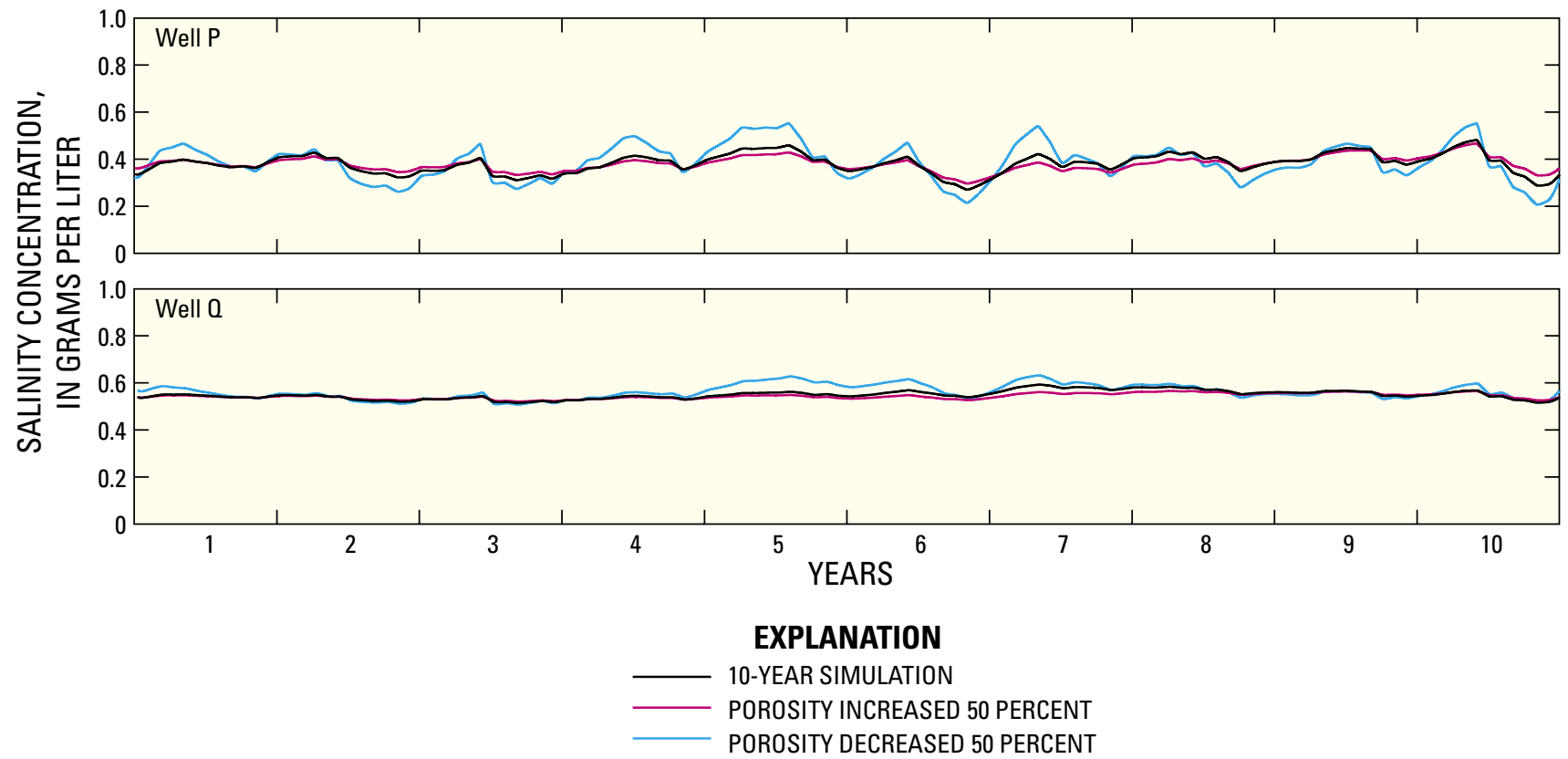

Figure 57. Total dissolved-solids concentration over time at simulated observation wells $P$ and $Q$, resulting from changes in porosity. 
and seaward. Salinity in the 10-year model apparently is not sensitive to an increase in porosity, but is slightly sensitive to a decrease in porosity. The overall average of salinity concentrations in simulated observation wells P and Q apparently are the same, however, showing no net inward or seaward movement of the saltwater interface with respect to porosity changes.

The model is not sensitive to 25 -percent increases or decreases in maximum evapotranspiration rates (extinction depth was held constant) (fig. 58), but is highly sensitive to a 50-percent decrease in precipitation or recharge (fig. 59). Salinity concentrations increase in the simulated Biscayne aquifer and increase even more in the simulated lower part of the surficial aquifer system when recharge is decreased. The model simulates the largest well field in Broward County, thus this model would be considered a "worst-case scenario." This analysis revealed that the location of the saltwater interface is very sensitive to rainfall, indicating that a severe drought could move the saltwater interface inland and threaten ground-water resources.

The 10-year simulation indicates that the location of the saltwater interface is sensitive to drought, which moves the toe inland. The abundant rainfall data can be used to predict seasonal rainfall amounts relatively well in the area. In some instances, however, evapotranspiration has a substantial effect on net recharge and is much more difficult to estimate. Although this model apparently is not sensitive to evapotranspiration, the process is an important factor in the total recharge in southeastern Florida.
The model is sensitive to dispersivity and horizontal hydraulic conductivity. Because of model limitations, computer run times, lack of knowledge on small-scale lithologic heterogeneity, and incomplete description of hydrologic conductivity, the model cannot include sufficient detail to reproduce the mixing that occurs in the field. Therefore, hydraulic conductivity is averaged, and a dispersivity value is used to create mixing in the model. Changes in dispersivity move the saltwater interface inland or seaward depending on the depth. Dispersivity is often changed during model calibration to match simulated salinity concentrations with field data.

\section{Model Limitations}

Numerical models of ground-water flow are limited in their representation of the physical system because the models contain simplifications and assumptions that may or may not be valid. Results from ground-water flow models contain some degree of uncertainty primarily because detailed threedimensional distributions of aquifer parameters are rarely, if ever, available. Results from solute-transport models have more associated uncertainty because they are dependent on ground-water velocities calculated from flow models and have uncertain parameters specific to solute transport. Variabledensity, ground-water flow and transport models have even more uncertainty and error because ground-water velocities are affected by solute concentrations. Results from variabledensity models must be evaluated with caution due to uncertainties and potential errors inherent in these types of models.

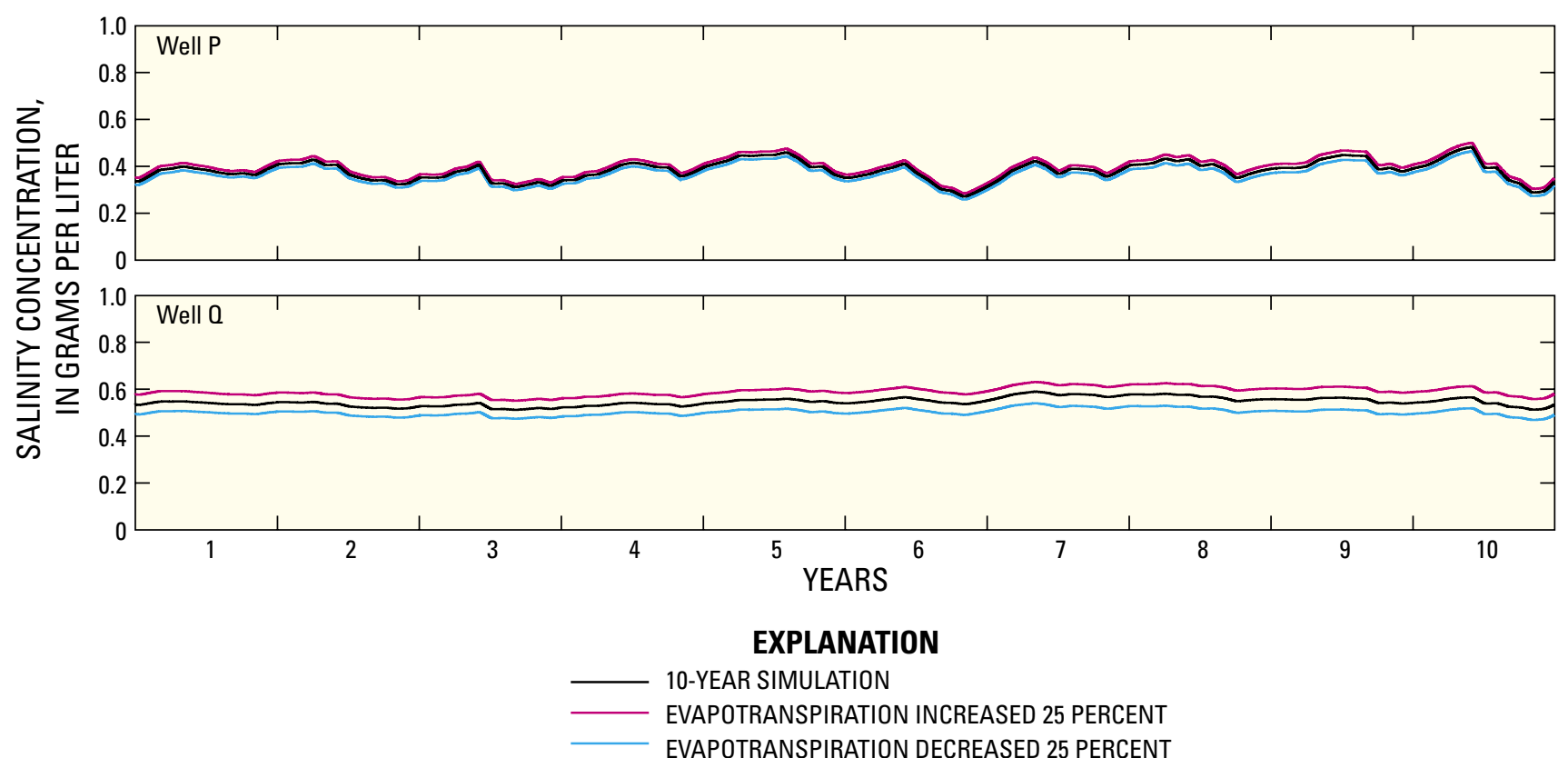

Figure 58. Total dissolved-solids concentration over time at simulated observation wells $P$ and $Q$, resulting form changes in evapotranspiration. 


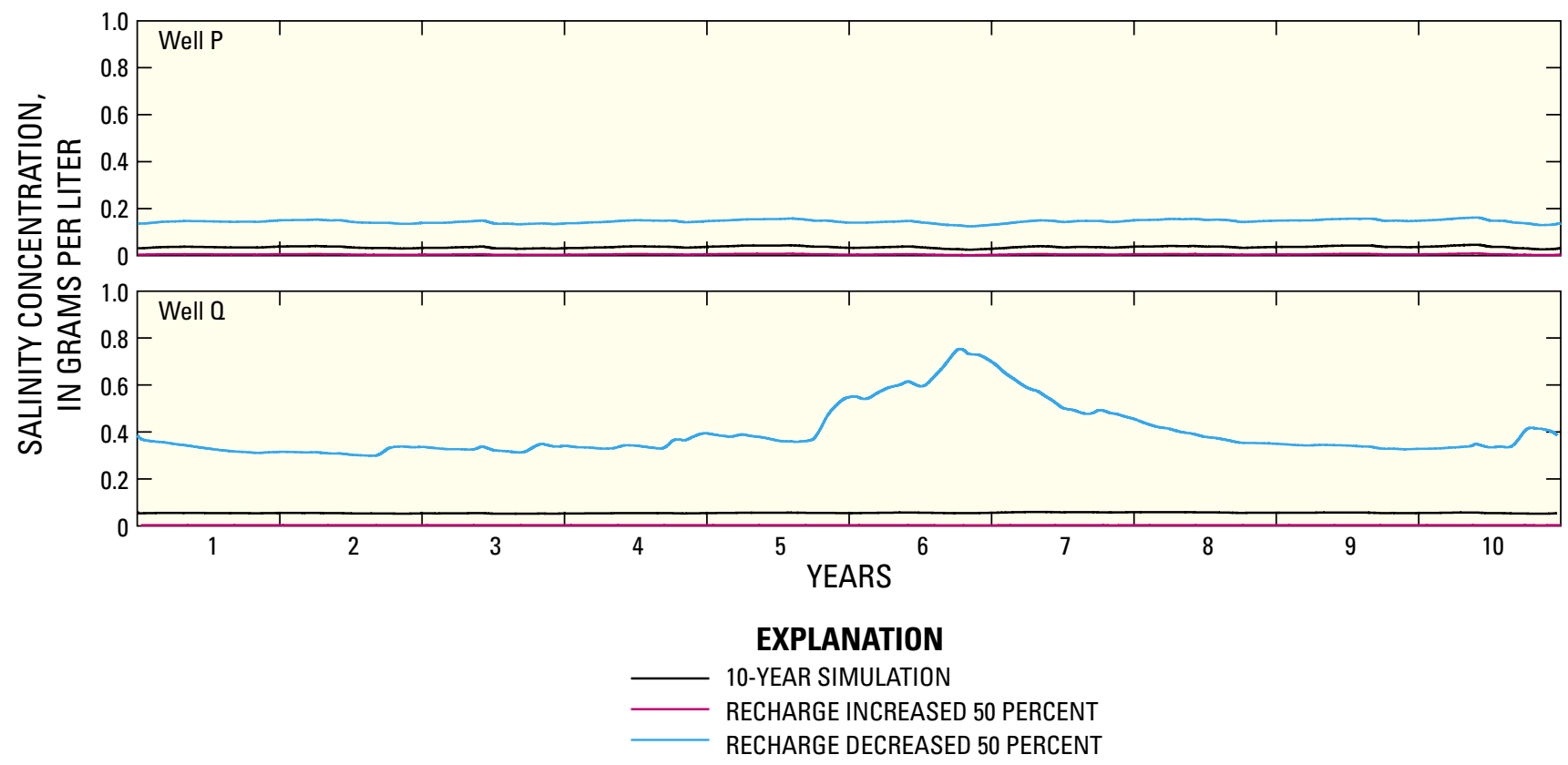

Figure 59. Total dissolved-solids concentration over time at simulated observation wells $\mathrm{P}$ and $\mathrm{Q}$, resulting from changes in recharge.

The representative model developed for this study clearly has uncertainty and error. Limitations in the numerical model that may cause errors in the results can be divided into two categories: invalid assumptions or approach implemented by the numerical simulation code; and inaccurate conceptual model, aquifer parameters, boundary conditions, or initial conditions.

SEAWAT (Guo and Langevin, 2002) is a relatively new code that is gaining use by ground-water modelers. The code has been verified with numerous benchmark problems, and results typically compare well with those from other codes and analytical solutions. Inherent in the SEAWAT code are some assumptions that may limit the reliability of the numerical models developed for this study. The most limiting assumption is that of an equivalent porous medium. Numerous investigators have documented the presence of preferential pathways in the Biscayne aquifer. These pathways may provide the mechanisms for increased flow toward the coast that may affect the location of the saltwater interface. The SEAWAT code and other finite-difference codes generally are not designed to simulate conduit flow. Instead, the effects of conduits are indirectly incorporated into the model by increasing the bulk hydraulic conductivity. At large scales, this approach is probably valid for simulating flow volumes, but may not accurately represent the transport processes. The accurate simulation of flow volumes in variable-density, ground-water systems depends on the accurate simulation of the transport processes. Although the representative model seems to reasonably represent the flow and transport processes, there is a level of inherent error in the model that cannot be quantified without a more thorough study of conduit flow in the surficial aquifer system.
Of the many assumptions used by the MODFLOW and MT3D codes, and hence the SEAWAT code, several are worthy of discussion. The explicit coupling method in the SEAWAT code uses a one time-step lag between solutions to the flow and transport equations. An evaluation of this approach indicates that a one time-step lag does not introduce large errors, but the potential for error does exist. The assumption of isothermal conditions may also limit the results of the models developed for this study. Thermal gradients can affect fluid density, and thus, ground-water flow patterns. Thermal gradients have been observed in the Biscayne aquifer, but seem to have little effect on ground-water flow. SEAWAT does not account for variations in viscosity; however, previous studies suggested that viscosity variations are not important unless fluid densities exceed $1,200 \mathrm{~kg} / \mathrm{m}^{3}$. For this study, fluid densities do not exceed $1,025 \mathrm{~kg} / \mathrm{m}^{3}$, suggesting that variations in fluid viscosity probably do not affect groundwater flow.

The processes of rainfall, runoff, recharge, and evapotranspiration were difficult to represent in the representative model because of their complex interrelations. Simplifications were made in order to represent these processes in the model, thus adding to the reliability of model results. For example, the model does not simulate evapotranspiration from the unsaturated zone, which may be an important process along the Atlantic Coastal Ridge where the zone is relatively thick. The quantity of unsaturated zone evapotranspiration probably is indirectly included in one of the other model processes such as runoff, baseflow to canals, or evapotranspiration from the water table. 
Horizontal and vertical discretization in the representative model also introduce error in model results. Because the model cells are $150 \times 150 \times 7.5 \mathrm{~m}$, the effects of the canal and well field are averaged over large volumes. This averaging will cause results from the regional-scale model to be imprecise at smaller scales. Additionally, the large model cells cannot simulate smaller effects, such as changes in hydraulic conductivity, which increase the dispersion of salts across the saltwater interface. This lack of detail may limit the capability of the model to accurately simulate the position and characteristics of the freshwater-saltwater transition zone.

Temporal averaging of tides, recharge, and canal stage in the 10-year representative model also affects the dispersion of salts across the saltwater interface. By increasing dispersivity, the model compensates for this averaging. Increasing dispersivity also increases error in the model results with respect to the location and movement of the saltwater interface.

\section{Summary and Conclusions}

Saltwater intrusion in Broward County is a complicated issue because of the factors that affect movement of the saltwater interface. This study originally began with the goal of assessing the effects that upstream canal stage have on saltwater intrusion; however, as research progressed, it was apparent that other factors, such as rainfall and pumpage, also affected saltwater interface movement.

Water levels in Broward County are affected by rainfall, well-field pumpage, canal stage, tides, sea-level rise, and evapotranspiration. This study examined these influences to evaluate effects on saltwater intrusion and movement of the saltwater interface by analyzing field data and by developing a variable-density model of a representative area in Broward County.

Short-term results (10 years or less) from modeling indicate that the primary factors affecting ground-water heads are somewhat different from those affecting saltwater interface movement. Head changes near the well field are affected by pumpage, the change in head between the upstream and downstream canal, and rainfall. In contrast, regression analyses indicated that rainfall has the greatest effect on saltwater interface movement in the Biscayne aquifer and the lower part of the surficial aquifer system near the well field. Near the canal, linear regression analyses indicated that the difference between the upstream and downstream canal stage has the greatest effect on saltwater interface movement. These model results indicated that saltwater interface movement seems to be more affected by ground-water flow in the vertical direction than the horizontal direction.

Data analysis showed some similar results to the model, indicating that rainfall does have an effect on saltwater interface movement near the well field. Well-field pumpage and upstream canal stage also play a role in saltwater interface movement near the well field. Both the model and data indicated that rainfall affects vertical flow in the Biscayne aquifer; downward flow occurs during large rainfall events. Similar to the model, upstream canal stage has the greatest effect on saltwater interface movement near the canal. Data analysis and model results also indicated that tidal effects on the water levels and saltwater interface can be seen up to 4.5 $\mathrm{km}$ inland from the coast and about $41 \mathrm{~m}$ deep. Data analysis indicated that gate openings and pumping at control structures affect movement of the saltwater interface.

The model indicates that a short-term 3-year drought will affect the saltwater interface location for a few years; however, a short-term drought will have little effect on the long-term location of the saltwater interface in the Biscayne aquifer. Short-term droughts, however, could have long-term effects on saltwater intrusion and/or upconing in the lower part of the surficial aquifer system. Therefore, monitoring wells located only within the Biscayne aquifer would not reflect the effect of saltwater intrusion/upconing in the lower part of the surficial aquifer system.

For the long-term effects on the location of the saltwater interface, upstream canal stage seems to play the most important role. Considering the current location of the saltwater interface, the model indicated that interface movement could be reversed by raising canal water levels. A longer period of raised canal water levels is required, however, to reverse saltwater intrusion that has already occurred. Modeling and geophysical logging data also indicated that the saltwater interface may not have stabilized in the entire county, and that the advancement of saltwater intrusion may still be occurring as a result of the original drainage of the wetlands in the early 1900s.

Modeling results indicated that for the long term (greater than 10 years), a relation exists between water levels near the well field and movement of the saltwater interface. Even though the $1-\mathrm{ft}(0.3048-\mathrm{m})$ rule is rarely met, a similar criterion could be used. In time periods of less than 10 years, however, the model indicated that the $1-\mathrm{ft}$ rule is met only sporadically and there is not yet inward movement of saltwater, thus the $1-\mathrm{ft}$ rule may not be a valid criterion for saltwater intrusion. Modeling also showed that if sea-level rise is greater than $48 \mathrm{~cm}$ over the next 100 years, well fields may be vulnerable to chloride contamination.

\section{References Cited}

Andersen, P.F., Mercer, J.W., and White, H.O., Jr., 1988, Numerical modeling of salt-water intrusion at Hallandale, Florida: Ground Water, v. 26, no. 5, p. 619-630.

Baxter, G.P., and Wallace, C.C., 1916, Changes in volume upon solution in water of halogen salts of alkali metals: American Chemical Society Journal, no. 38, p. 70-104.

Bearden, H.W., 1972, Ground water in the Hallandale area, Florida: Tallahassee, Florida Geological Survey Information Circular 77, $32 \mathrm{p}$. 
Bearden, H.W., 1974, Ground-water resources of the Hollywood area, Florida: Tallahassee, Florida Geological Survey Report of Investigations 77, 35 p.

Bishop, C.M., 1995, Neural networks for pattern recognition: Oxford, University Press.

Broward County Department of Planning and Environmental Protection, 2000, Delineation of saltwater intrusion: Accessed on July 21, 2002, at http://www.broward.org/ moi00612.pdf

Brown, R.H., and Parker, G.G., 1945, Saltwater encroachment in limestone at Silver Bluff, Miami, Florida: Economic Geology, v. 40, no. 4, p. 235-262.

Camp, Dresser, and McKee, Inc., 1980, Prospect well field impact analysis: City of Fort Lauderdale, 96 p.

Causaras, C.R., 1985, Geology of the surficial aquifer system, Broward County, Florida: U.S. Geological Survey WaterResources Investigations Report 84-4068, 167 p., 2 sheets.

Cooper, H.H., Jr., 1959, A hypothesis concerning the dynamic balance of fresh water and salt water in a coastal aquifer: Journal of Geophysical Research, v. 64, no. 4, p. 461-467.

Cooper, H.H., Kohout, F.A., Henry, H.R., and Glover, R.E., 1964, Sea water in coastal aquifers: U.S. Geological Survey Water-Supply Paper 1613-C, 84 p.

Dunn, Darrel, 2001, Three-dimensional analysis of saltwater intrusion: City of Pompano Beach area, Broward County, Florida: Broward County Department of Planning and Environmental Protection Technical Report Series TR-01-06, August 2001.

Fish, J.E., 1988, Hydrogeology, aquifer characteristics, and ground-water flow of the surficial aquifer system, Broward County, Florida: U.S. Geological Survey Water-Resources Investigations Report 87-4034, 92 p.

Gelhar, L.W., 1986, Stochastic subsurface hydrology, from theory to applications: Water Resources Research, v. 22, no. 9, p. 135S-145S.

German, E.R., 2000, Regional evaluation of evapotranspiration in the Everglades: U.S. Geological Survey Water-Resources Investigations Report 00-4217, 48 p.

Grantham, R.G., and Sherwood, C.B., 1968, Chemical quality of waters of Broward County, Florida: Tallahassee, Florida Geological Survey Report of Investigations 51, 52 p.

Guo, Weixing, and Langevin, C.D. 2002, User's Guide to SEAWAT: A computer program for simulation of threedimensional variable-density ground-water flow: U.S. Geological Survey Open-File Report 01-434, 77 p.

Harbaugh, A.W., and McDonald, M.G., 1996, User's documentation for MODFLOW-96, an update to the U.S. Geological Survey modular finite-difference ground-water flow model: U.S. Geological Survey Open-File Report 96-485, $56 \mathrm{p}$.

Hittle, C.D., 1999, Delineation of saltwater intrusion in the surficial aquifer system in eastern Palm Beach, Martin, and St. Lucie Counties, Florida, 1997-98: U.S. Geological Survey Water-Resources Investigations Report 99-4214, 1 sheet.
Howie, Barbara, 1987, Chemical characteristics of water in the surficial aquifer system, Broward County, Florida: U.S. Geological Survey Water-Resources Investigations Report 86-4330, 2 sheets.

Hoy, N.D., 1952, Two maps of Dade County, Florida, showing approximate position of the 1,000-PPM isochlor as of 1951 and approximate area of potential saltwater penetration under 1945 conditions: U.S. Geological Survey Open-File Report FL-52001, 2 sheets.

Hoy, N.D., and others, 1951, Six cross sections and an index map of the Miami area, Florida, showing changes in the position of the salt front in the Biscayne aquifer from 1946 to 1950: U.S. Geological Survey Open-File Report FL-51002.

Hubbert, M.K., 1940, The theory of ground-water motion: Journal of Geology, v. 48, no. 8, pt. 1, p. 785-944.

Intergovernmental Panel on Climate Change, 2001, Climate change 2001: The scientific basis: United Kingdom and New York, Cambridge University Press, $881 \mathrm{p}$.

Jordan, C.L., 1984, Florida's weather and climate: Implications for water, in Fernald, E.A., and Patton, D.J., eds., Water Resources Atlas of Florida: Tallahassee, Florida State University, Institute of Science and Public Affairs, p. 18-35.

Klein, Howard, 1957, Salt-water encroachment in Dade County, Florida: Tallahassee, Florida Geological Survey Information Circular No. 9, 5 p.

Klein, Howard, 1965, Probable effect of Canal 111 on saltwater encroachment, southern Dade County, Florida: U.S. Geological Survey Open-File Report FL-65002, 26 p.

Klein, Howard, and Ratzlaff, K.W., 1989, Changes in saltwater intrusion in the Biscayne aquifer, Hialeah-Miami Springs area, Dade County, Florida: U.S. Geological Survey Water-Resources Investigations Report 87-4249, 1 sheet.

Klein, Howard, and Waller, B.G., 1985, Synopsis of saltwater intrusion in Dade County, Florida, through 1984: U.S. Geological Survey Water-Resources Investigations Report 85-4101, 1 sheet.

Kohout, F.A., 1960a, Cyclic flow of salt water in the Biscayne aquifer of southeastern Florida: Journal of Geophysical Research, v. 65, no. 7, p. 2133-2141.

Kohout, F.A., 1960b, Flow pattern of fresh and salt water in the Biscayne aquifer of the Miami area, Florida: International Association of Scientific Hydrology Publication 52, p. 440-448.

Kohout, F.A., 1961a, Case history of salt water encroachment caused by a storm sewer in Miami: American Water Works Association Journal, v. 53, no. 11, p. 1408-1416.

Kohout, F.A., 1961b, Fluctuations of ground-water levels caused by dispersion of salts: Journal of Geophysical Research, v. 66, no. 8, p. 2429-2434.

Kohout, F.A., 1964, The flow of fresh water and salt water in the Biscayne aquifer of the Miami area, Florida: U.S. Geological Survey Water-Supply Paper 1613-C, p. 12-32. 
Kohout, F.A., 1967, Relation of seaward and landward flow of ground water to the salinity of Biscayne Bay at Miami, Florida: U.S. Geological Survey Open-File Report 67-136, 98 p.

Kohout, F.A., and Hoy, N.D., 1953, Research on salt-water encroachment in the Miami area, Florida: U.S. Geological Survey Open-File Report FL-53004, 20 p.

Konikow, L.F., and Reilly, T.E., 1999, Seawater intrusion in the United States, in Bear, Jacob, and others, eds., Seawater intrusion in coastal aquifers-Concepts, Methods and Practices: Dordrecht, The Netherlands, Kluwer Academic Publishers, p. 463-506.

Koszalka, E.J., 1995, Delineation of saltwater intrusion in the Biscayne aquifer, eastern Broward County, Florida, 1990: U.S. Geological Survey Water-Resources Investigations Report 93-4164, 1 sheet.

Kwiatkowski, P.J., 1987, Numerical simulation of seawater intrusion, Cutler Ridge, Florida: Tampa, University of South Florida, M.S. Thesis, 85 p.

Land, L.F., 1975, Effects of lowering interior canal stages on salt-water intrusion into the shallow aquifer in southeast Palm Beach County, Florida: U.S. Geological Survey OpenFile Report 75-74, 59 p.

Land, L.F., Rodis, H.G., and Schneider, J.J., 1973, Appraisal of the water resources of eastern Palm Beach County, Florida: Tallahassee, Florida Geological Survey Report of Investigations 67, $64 \mathrm{p}$.

Langevin, C.D., 2001, Simulation of ground-water discharge to Biscayne Bay, southeastern Florida: U.S. Geological Survey Water-Resources Investigations Report 00-4251, 127 p.

Leach, S.D., and Grantham, R.G., 1966, Salt-water study of the Miami River and its tributaries, Dade County, Florida: Tallahassee, Florida Geological Survey Report of Investigations 45, $36 \mathrm{p}$.

Leach, S.D., Klein, Howard, and Hampton, E.R., 1972, Hydrologic effects of water control and management of southeastern Florida: Tallahassee, Florida Bureau of Geology Report of Investigations $60,115 \mathrm{p}$.

Lietz, A.C., 1991, Altitude of the water table in the Biscayne aquifer, Broward County, Florida, April, 26-29, 1988: U.S. Geological Survey Open-File Report 92-31, 1 sheet.

Lietz, A.C., 2003, Quality-assurance plan for water-quality activities of the U.S. Geological Survey in Miami, Florida: Open-File Report 03-195, 72 p.

McCoy, H.J., and Hardee, Jack, 1970, Ground-water resources of the lower Hillsboro Canal area, southeastern Florida: Tallahassee, Florida Bureau of Geology Report of Investigations 55, $44 \mathrm{p}$.

McDonald, M.G., and Harbaugh, A.W., 1988, A modular three-dimensional finite-difference ground-water flow model: U.S. Geological Survey Techniques of WaterResources Investigations, book 6, chap. A1, 586 p.

McPherson, B.F., and Halley, Robert, 1996, The south Florida environment-A region under stress: U.S. Geological Survey Circular 1134, $61 \mathrm{p}$.
Merritt, M.L., 1996, Assessment of saltwater intrusion in southern coastal Broward County, Florida: U.S. Geological Survey Water-Resources Investigations Report 96-4221, $133 \mathrm{p}$.

Merritt, M.L., 1997, Tests of subsurface storage of freshwater at Hialeah, Dade County, Florida, and numerical simulation of the salinity of recovered water: U.S. Geological Survey Water-Supply Paper 2431, 114 p.

Parker, G.G., 1945, Saltwater encroachment in southern Florida: Journal of the American Water Works Association, v. 37, no. 6, p. 526-542.

Parker, G.G., Ferguson, G.E., and Love, S.K., 1944, Interim report on the investigations of water resources in southeastern Florida with special reference to the Miami area in Dade County: Tallahassee, Florida Geological Survey Report of Investigations 4, 39 p.

Parker, G.G., Ferguson, G. E., Love, S. K., and others, 1955, Water resources of southeastern Florida with special reference to the geology and ground water of the Miami area: U.S. Geological Survey Water-Supply Paper 1255, 965 p.

Restrepo, J.I., Bevier, Cindy, and Butler, David, 1992, A threedimensional finite difference ground water flow model of the surficial aquifer system, Broward County, Florida: West Palm Beach, South Florida Water Management District Technical Publication DRE:314, 261 p.

Ripley, B.D., 1994, Neural networks and related methods for classification: Journal of the Royal Statistical Society, v. 56, no. 3, p. 409-456.

Ripley, B.D., 1996, Pattern recognition and neural networks: New York, Cambridge University Press, 403 p.

Rodis, H.G., 1973, Encroaching salt water in northeast Palm Beach County, Florida: Tallahassee, Florida Bureau of Geology Map Series 59, 1 sheet.

Schroeder, M.C., Klein, Howard, and Hoy, N.D., 1958, Biscayne aquifer of Dade and Broward Counties, Florida: Tallahassee, Florida Geological Survey Report of Investigations $17,56 \mathrm{p}$.

Scott, W.B., Land, L.F., and Rodis, H.G., 1977, Saltwater intrusion in the shallow aquifer in Palm Beach and Martin Counties, Florida: U.S. Geological Survey Water-Resources Investigations Report 76-135, 1 sheet.

Segol, Genevieve, and Pinder, G.F., 1976, Transient simulation of saltwater intrusion in southeastern Florida: Water Resources Research, v. 12, no. 1, p. 65-70.

Sherwood, C.B., 1959, Ground-water resources of the Oakland Park area of eastern Broward County, Florida: Tallahassee, Florida Geological Survey Report of Investigations 20, $40 \mathrm{p}$.

Sherwood, C.B., McCoy, H.J., and Galliher, C.F., 1973, Water resources of Broward County, Florida: Tallahassee, Florida Geological Survey Report of Investigations 65, 141 p.

Shoemaker, W.B., and Edwards, K.M., 2003, Potential for saltwater intrusion into the lower Tamiami aquifer near Bonita Springs, southwestern Florida: U.S. Geological Survey Water-Resources Investigations Report 03-4262, 74 p. 
Sonenshein, R.S., 1997, Delineation and extent of saltwater intrusion in the Biscayne aquifer, eastern Dade County, Florida, 1995: U.S. Geological Survey Water-Resources Investigations Report 96-4285, 1 sheet.

Sonenshein, R.S., and Koszalka, E.J., 1996, Trends in watertable altitude (1984-93) and saltwater intrusion (1974-93) in the Biscayne aquifer, Dade County, Florida: U.S. Geological Survey Open-File Report 95-705, 2 sheets.

Sonntag, W.H., 1987, Chemical characteristics of water in the surficial aquifer system, Dade County, Florida: U.S. Geological Survey Water-Resources Investigations Report 87-4080, 42 p.

South Florida Water Management District, 2000a, Lower East Coast Regional Water Supply Plan: May 2000, CD-ROM.

South Florida Water Management District, 2000b, Minimum flows and levels for Lake Okeechobee, the Everglades, and the Biscayne aquifer: February 29, 2000, 140 p.

South Florida Water Management District, 2002, Basis of review for water use permit applications within the South Florida Water Management District: Section 3.4.

Stephens, J.C., and Stewart, E.H., 1963, A comparison of procedures for computing evaporation and evapotranspiration: Publication No. 62 of IASH Commission for Evaporation, Transactions of IUGG, Florida Agricultural Experiment Station Journal series no. 1664, p. 123-133.

Swayze, L.J., 1980a, Altitude of water table and saline-water front, Hialeah-Miami Springs well field area, Biscayne aquifer, Dade County, Florida, May 12, 1980: U.S. Geological Survey Open-File Report 80-1211, 1 sheet.

Swayze, L.J., 1980b, Altitude of water table and saline-water front, Hialeah-Miami Springs well field area, Dade County, Florida, May 3, 1978: U.S. Geological Survey Open-File Report 80-588, 1 sheet.
Swayze, L.J., 1980c, Altitude of water table and saline-water front, Hialeah-Miami Springs well field area, Dade County, Florida, October 5, 1979: U.S. Geological Survey Open-File Report 80-559, 1 sheet.

Swayze, L.J., 1980d, Water-level contour and salt-front map, Hialeah-Miami Springs well field area, Dade County, Florida, October 13, 1978: U.S. Geological Survey OpenFile Report 80-8, 1 sheet.

Tarver, G.R., 1964, Hydrology of the Biscayne aquifer in the Pompano Beach area, Broward County, Florida: Tallahassee, Florida Geological Survey Report of Investigations 36, $47 \mathrm{p}$.

Technos, Inc. 1996, Quantitative relationship between time domain electromagnetic measurements and water quality data: Broward County P.O. No. PC5EQ00001077, Technos Project No. 95-102.

U.S. Environmental Protection Agency, 1977, Public Law 104182 104th Congress: Safe Drinking Water Act: Accessed on July 21, 2003, at http://www.epa.gov/safewater/sdwa/text. html.

U.S. Geological Survey, 1986, Pompano Beach, Florida, Quadrangle: 7.5-minute series, 1 sheet.

Vorhis, R.C., 1948, Geology and ground water of the Fort Lauderdale area, Florida: Tallahassee, Florida Geological Survey Report of Investigations 6, 32 p.

Weiss, S.M., and Indurkhya, Nitin, 1998, Predictive data mining: A practical guide: San Francisco, Calif., Morgan Kaufmann Publishers, 228 p.

Zheng, Chunmiao, and Wang, P.P., 1998, MT3DMS, A modular three-dimensional multispecies transport model for simulation of advection, dispersion and chemical reactions of contaminants in groundwater systems: Vicksburg, Miss., Waterways Experiment Station, U.S. Army Corps of Engineers. 


\section{Appendix}

\section{Broward County Model}

The South Florida Water Management District (SFWMD) constructs flow models to develop water-management scenarios and to aid in the Everglades restoration effort. The most recent model constructed for Broward County uses a modified version of the U.S. Geological Survey three-dimensional, finite-difference code called MODFLOW-96 (Harbaugh and McDonald, 1996). This model is similar to MODFLOW, but adds the Wetland and Diversion packages. The purpose in adding these packages is to create a surface- and ground-water connection that is not included in the original MODFLOW code and to add the water-conservation areas (fig. 4) to the flow model. Many MODFLOW models have been developed for coastal areas of southern Florida; however, none of the existing models can be used to evaluate saltwater intrusion because they lack the ability to solve variable-density flow and transport. This appendix describes how a complex MODFLOW model can be altered to run in SEAWAT as a variable-density model. The process described herein could be used to convert other existing MODFLOW models to the SEAWAT format.

The study area (fig. A1) contains a model grid discretized into 456 rows and 371 columns in which each cell represents a 152.4- by $152.4-\mathrm{m}$ area. The grid contains five layers representing the different lithologic zones in the surficial aquifer system. The original SFWMD/MODFLOW model (South Florida Water Management District, 2000a) was calibrated for the period 1988-95. As part of this study, a variable-density model was constructed from the SFWMD/MODFLOW model for 1988-90. The 1988-90 data sets were available before the final calibrated version of the SFWMD/MODFLOW model, and running the model for only 3 years as opposed to 8 years saved computational time.

\section{Packages}

Before the Broward County MODFLOW model, or similar MODFLOW models, can be used with SEAWAT to evaluate saltwater intrusion or variable-density flow, some packages must be modified to conform to the SEAWAT format. SEAWAT uses traditional MODFLOW-88 packages with a few alterations. The standard modifications from MODFLOW (McDonald and Harbaugh, 1988) can be found in Guo and Langevin (2002). The Broward County model also includes packages that are not standard for the published version of MODFLOW, and therefore, cannot be used in SEAWAT. For example, SEAWAT does not have a Wetlands package as does the SFWMD/MODFLOW model. Because SEAWAT is a combination of MODFLOW-88 and MT3DMS (Zheng and Wang, 1998), packages for MT3DMS, which is the transport part of the code, have to be created to enable variable-density flow and transport.
The following MODFLOW packages are used in the Broward County MODFLOW model:

\begin{tabular}{ll}
\hline AGWL & Agricultural well \\
\hline BAS & Basic \\
\hline BCF & Block-centered flow \\
\hline DIV & Diversion (part of the Wetlands package) \\
\hline DRN & Drain \\
\hline EVT & Evapotranspiration \\
\hline GEN & Wetlands \\
\hline GHB & General-head boundary \\
\hline OC & Output control \\
\hline RCH & Recharge \\
\hline RIV & River \\
\hline SIP & Strongly implicit procedure solver \\
\hline WEL & Well \\
\hline
\end{tabular}

SEAWAT uses the following packages:

\begin{tabular}{ll}
\hline ADV & Advection \\
\hline BAS & Basic \\
\hline BCF & Block-centered flow \\
\hline BTN & Basic transport \\
\hline DRN & Drain \\
\hline EVT & Evapotranspiration \\
\hline GCG & Solver \\
\hline GHB & General-head boundary \\
\hline OC & Output control \\
\hline PCG2 & Preconditioned conjugate gradient solver \\
\hline RCH & Recharge \\
\hline RIV & River \\
\hline SSM & Streaming source metafile \\
\hline WEL & Well \\
\hline
\end{tabular}

The overall development and changes in each package will be discussed, except for the alterations published in Guo and Langevin (2002). The development of MODFLOW-88 and MT3DMS packages can be found in McDonald and Harbaugh (1988) and Zheng and Wang (1998); therefore, specific details are not provided here. 


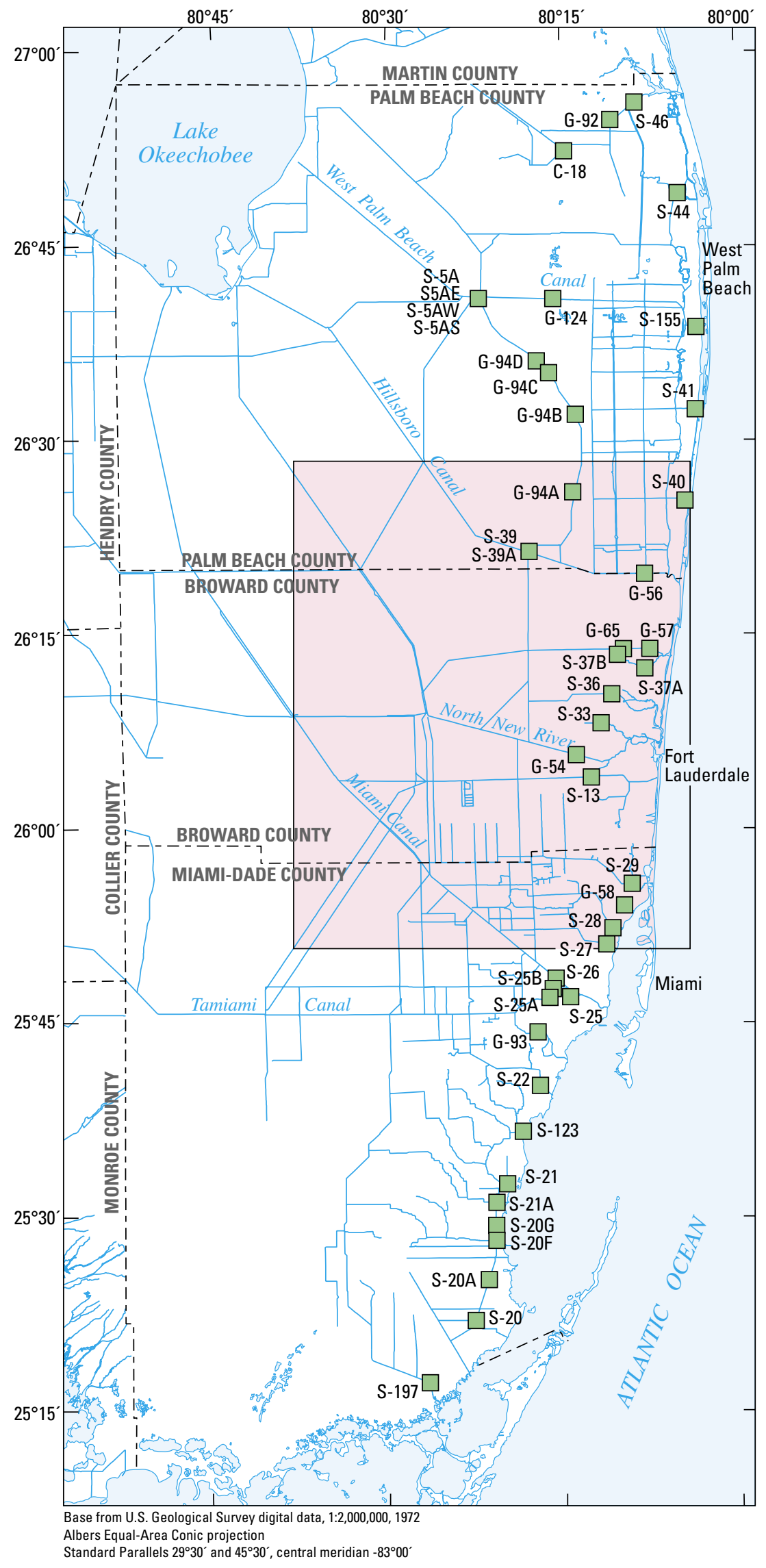

\section{EXPLANATION}

\begin{tabular}{|c|c|c|c|c|}
\hline & \multicolumn{4}{|c|}{$\begin{array}{l}\text { LOCATION OF MODEL } \\
\text { AREA }\end{array}$} \\
\hline & \multicolumn{4}{|c|}{$\begin{array}{l}\text { CONTROL STRUCTURE } \\
\text { AND NUMBER }\end{array}$} \\
\hline 0 & 5 & & $15 \mathrm{~K}$ & JMETERS \\
\hline 0 & & & 10 & 15 MILES \\
\hline
\end{tabular}

Figure A1. Location of study area for the Broward County model, Broward County, Florida. 


\section{Basic (BAS)}

The SFWMD version of MODFLOW uses a Fortran OPEN statement in this file to make the connection between the file name and the unit number. The unit numbers in the Basic (BAS) package inform the SEAWAT code which MODFLOW packages to include in the simulation. The main changes in this file were the elimination of the Wetlands (GEN) and Diversion (DIV) packages, the change of solvers, and the alteration of the IBOUND array. The SFWMD/ MODFLOW model used the Strongly Implicit Procedure (SIP) solver, and the variable-density model created in SEAWAT used the Preconditioned Conjugate Gradient 2 (PCG2) solver for the flow equation.

Another change in the Basic package is the inclusion of numerical arrays for SEAWAT. The Broward County Basic package was set up to use unit numbers for external files, which contain numerical arrays such as the IBOUND array in the BASIC package. For the SEAWAT model, these arrays are placed directly in the Basic package rather than as external files.

Another change between the two models is the IBOUND array and the number of active and inactive cells. Because the Broward County model simulates only flow (and not transport of saltwater from the ocean), the freshwater-saltwater interface is designated using general-head boundary (GHB) cells, and no-flow (inactive) cells are used farther east (fig. A2A). For the SEAWAT model, the GHB cells representing the saltwater intrusion line were removed, and all cells east of this boundary, identified as constant head (CHD), were made active in the model domain (fig. A2B). Constant-head cells were placed in layer 1 where the ocean is simulated, and also were placed in layers 2 to 5 around the edge of the model where the ocean is simulated. The purpose for these changes is to enable variable-density flow and transport from the ocean. The cells in layer 1 where the Wetlands package is simulated are made inactive, and changes in the GHB package (discussed later) are made to accommodate this change.

\section{Block-Centered Flow (BCF), Drain (DRN), River (RIV), Evapotranspiration (EVT), and Recharge (RCH)}

The block-centered flow (BCF), Drain (DRN), River (RIV), Evapotranspiration (EVT), and Recharge (RCH) SFWMD packages were converted to standard MODFLOW-88 files. External numerical arrays were included directly in the new packages.
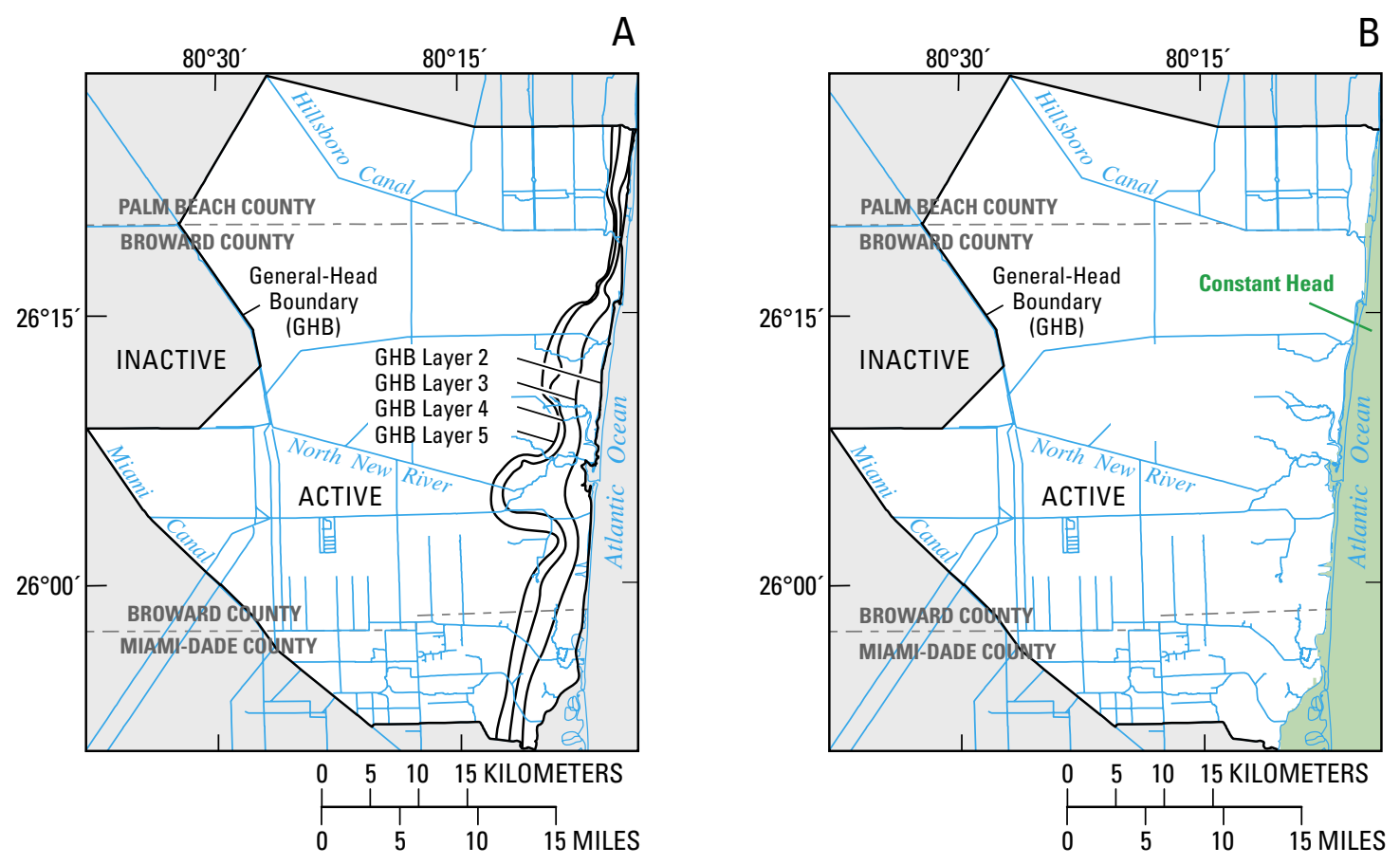

Figure A2. Second layer of the Broward County model with (A) South Florida Water Management District MODFLOW boundaries and active cells, and (B) SEAWAT model boundaries and active cells. 


\section{Well (WEL)}

The Broward County model had two well packages, one for agricultural wells and another for the remaining wells. The two packages were combined into one traditional MODFLOW-88 Well (WEL) package, and the pumpage volumes for each stress period were included in the one WEL package created for SEAWAT.

\section{Output Control (OC)}

The Output Control (OC) was kept identical between the two models.

\section{Strongly Implicit Procedure (SIP) to Preconditioned Conjugate Gradient 2 (PCG2)}

The original Broward County model used the Strongly Implicit Procedure (SIP) solver. For the SEAWAT variabledensity model, the Preconditioned Conjugate Gradient 2 (PCG2) solver was used to solve the flow equation.

\section{Wetlands (GEN) and Diversion (DIV) Converted to General-Head Boundary (GHB)}

The Wetlands (GEN) and Diversion (DIV) packages had to be removed to run the SEAWAT model. The removal of the two packages was accommodated for in the GHB package (fig. A2). This was accomplished by the following procedures:

- Running the original Broward County model.

- Printing the resulting heads from each stress period in the designated wetlands area into layer 2.

- Making the cells in layer 2 representative of the Wetlands package as part of the GHB package.

- Placing the resulting heads from the wetlands area as heads in the GHB package.

- Computing conductances for the GHB in the wetlands with conductance, $C$, defined as $C=K^{*} A / L$, where

- $K$ is vertical hydraulic conductivity. For this particular case, it is the peat horizontal conductivity, hyтис, specified in the Wetlands package multiplied by the anisotropy factor, vhymисr; therefore, K= hyтис $*$ vyhmисr.

- $A$ is the area of the cell $(152.4 \times 152.45 \mathrm{~m})$.

- $L$ is the length of the flow path. For this case, the peat thickness equals zbott - top layer_2, where $z b o t t$ is the elevation of the muck/peat top surface (land surface).

$-C=A($ hyтис $*$ vhymucr $) /(z b o t t-$ top layer_2 $)$
Subsequently, the input format to the GHB package would be:

\section{Layer Row Column Head Conductance}

where Layer is the layer number of the wetland cell, Row is the row number of the wetland cell, Column is the column number of the wetland cell, Head is the head taken from running the original Wetlands package, and Conductance is the hydraulic conductance between the aquifer cell and the wetlands.

The GEN and DIV packages are removed because the variable-density model for Broward County deals primarily with saltwater intrusion. Therefore, water levels and flows in the water- conservation areas of Broward County probably have little effect on the location and movement of the saltwater interface in eastern Broward County.

\section{Basic Transport Package (BTN)}

The Basic Transport Package (BTN) package for MT3D is comparable to the BAS package for MODFLOW. The BTN package is required for every simulation and contains information such as the number of layers, rows, columns, units used, ICBUND array, and so forth. Details on how to create the BTN package are given in Zheng and Wang (1998) and Guo and Langevin (2002). The ICBUND array in the BTN package is different than the IBOUND array in the BAS package, which is important for the purpose of the Broward County variable-density model. Because MT3D solves for the transport part of SEAWAT, the entire model grid does not need to be activated if saltwater intrusion in the eastern part of the grid is the focus. To save time and computer space, only the cells of interest (those that represent the coastal part of Broward County) for transport need to be activated. Therefore, cells in the BTN package are activated only for the eastern part of Broward County.

The BTN package also contains the initial concentrations for the variable-density model. For the purpose of evaluating saltwater intrusion, the active cells representing the ocean are given a concentration of $35 \mathrm{~g} / \mathrm{L}$, but are not held constant.

\section{Advection (ADV)}

The Advection (ADV) package contains the information needed to solve the advection term of the transport equation; in particular, the transport of contaminants by means of ground-water flow. There are different solutions to solve the advection term of the equation, one including the third-order Total Variation Diminishing (TVD) method. This method is used for the Broward County model because it minimizes the numerical problems in the transport of particles. Additionally, this method is the best solution for a model that contains cells of different sizes, such as the Broward County model grid. Specifications on creating the ADV package are in Zheng and Wang (1998). 


\section{Sink and Source Mixing (SSM)}

The Sink and Source Mixing (SSM) package stores the information needed to solve the source and sink components of the transport equation. (The Broward County model utilizes the implicit finite-difference method by using the Generalized Conjugate Gradient Solver, GCG, package.) The SSM package stores information on the concentrations of sinks and sources in the Broward County model. For example, a constant-head cell specified in MODFLOW, such as an ocean cell, can be set at a specific concentration that can be held constant or allowed to vary with the surrounding aquifer cells. For the Broward County model, the ocean cells were allowed to vary. Information on the cell locations and flow rates of the sinks and sources are from the MODFLOW calculations done in SEAWAT.

\section{Generalized Conjugate Gradient Solver (GCG)}

The Generalized Conjugate Gradient Solver (GCG) package solves the linear equations from the finite-difference form of the SSM package. The GCG package is activated to solve the SSM portion of the transport equation implicitly.

\section{Running Model}

The simulation was run after the packages were created. A single run typically takes between 3 and 7 days to complete depending on the computer, processor, memory, and so forth. The packages and output files can be greater than 1 gigabyte depending on how often the results are printed. To evaluate the location of the saltwater interface, the concentrations must be at dynamic equilibrium. The Broward County model reaches dynamic equilibrium when subsequent simulations result in the same ending concentrations. Model results obtained at dynamic equilibrium (fig. A3A) revealed that salinity concentrations in southern Broward County are much farther inland now than during the early 1990s. This model was not calibrated because of time constraints; however, a calibrated model could prove to be useful for predicting saltwater intrusion in Broward County.

Figure A3. Results from the variable-density Broward County model created from SEAWAT. Total dissolved-solids concentrations are shown for the last stress period at the end of 1990. Results from (A) layer 2 and (B) layer 4 (base of the Biscayne aquifer); the saltwater intrusion line from Broward Department of Planning and Environmental Protection (2000) is shown to compare the results from the approximate interface location.
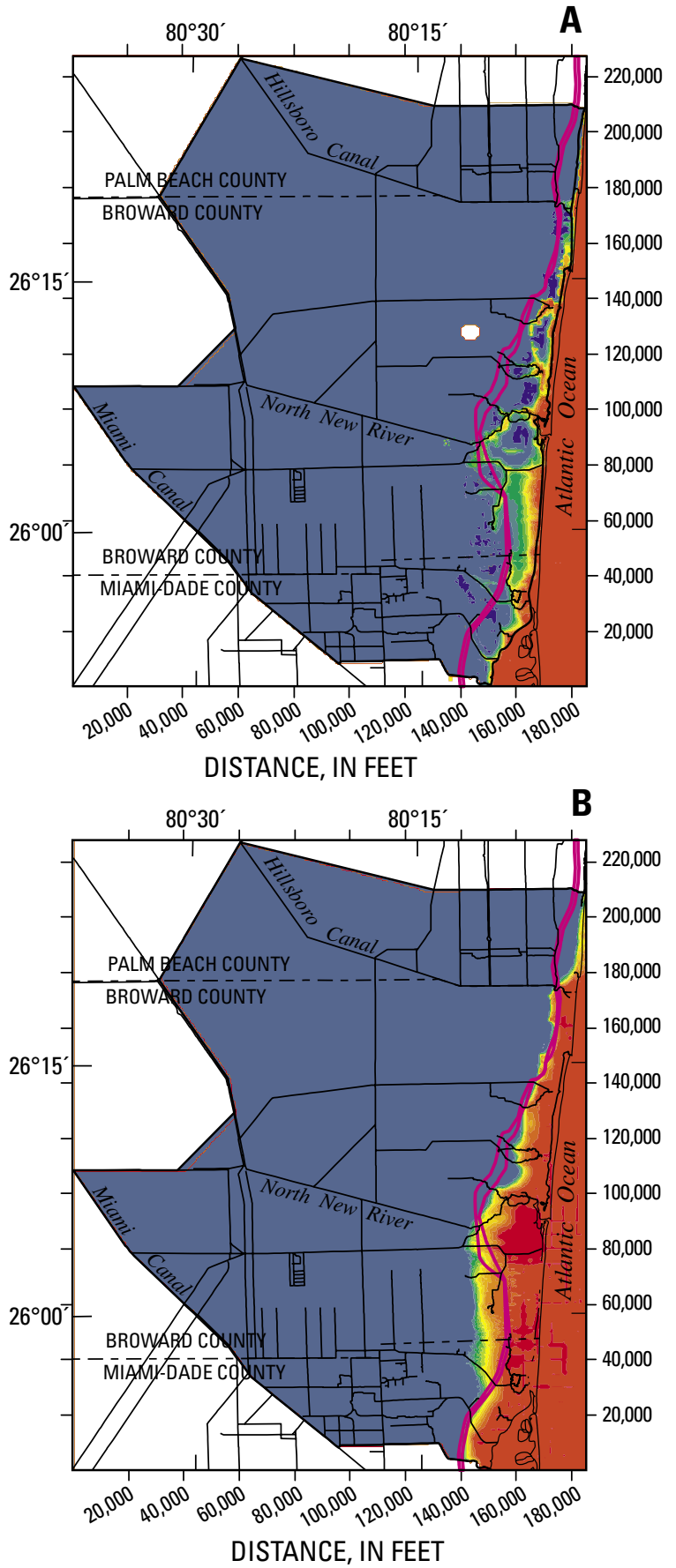

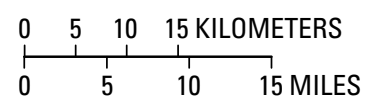

EXPLANATION

APPROXIMATE POSITION OF SALTWATER INTERFACE

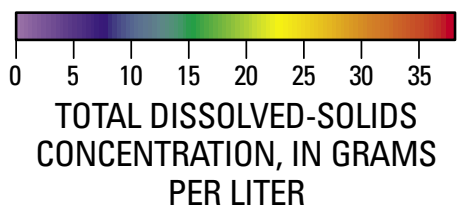

